University of San Diego

Digital USD

2003-05-01

\title{
The Relationship between Decision-Making and Accountability: A Case Study of Two State Community College Systems
}

Bonnie Ann Dowd EdD, MBA, BBA

University of San Diego

Follow this and additional works at: https://digital.sandiego.edu/dissertations

Part of the Leadership Studies Commons

\section{Digital USD Citation}

Dowd, Bonnie Ann EdD, MBA, BBA, "The Relationship between Decision-Making and Accountability: A Case Study of Two State Community College Systems" (2003). Dissertations. 705.

https://digital.sandiego.edu/dissertations/705

This Dissertation: Open Access is brought to you for free and open access by the Theses and Dissertations at Digital USD. It has been accepted for inclusion in Dissertations by an authorized administrator of Digital USD. For more information, please contact digital@sandiego.edu. 
The Relationship between Decision-making and

Accountability :

A Case Study of Two State Community College Systems

by

Bonnie Ann Dowd, B.B.A., M.B.A.

\section{Dissertation}

Presented to the Faculty of the Graduate School of The University of San Diego

in partial fulfillment

of the requirements

for the degree of

Doctor of Education

University of San Diego
School of Education

May 2003 


\author{
Copyright \\ by \\ Bonnie Ann Dowd \\ 2003
}




\section{Abstract}

Inherent to college governance in many community colleges throughout the nation is the expectation that a collegial or participatory model of decision-making is the appropriate mode of governance. This type of model structures an organization to allow the opportunity for all constituencies to participate in decision-making. Some states, such as California, have mandated a participatory decision-making process, commonly referred to as "shared governance" (AB1725) while others operate in a similar manner but not by legislative mandate. Regardless of the model of decision-making used to govern community colleges, most states are being asked to address educational accountability with regard to student performance outcomes. States, such as Florida, have reorganized their entire educational governance structure (SB1162) in an attempt to increase student success.

This case study provides an in-depth look at how internal structures of participatory decision-making respond to external requirements for accountability. The underlying premise for this study is that the decisionmaking process employed by a community college system at the state and local level significantly impacts any attempt to achieve accountability. The study examined two community 
college systems at the system (state) and college (local) level: California and Florida. Four research questions guided data collection with an additional sub-research question regarding how perceptions differed at the system and college level. A total of 29 respondents, at both the system and college levels, participated revealing meaningful insights about shared decision-making, accountability, student performance outcomes, performancebased funding and leadership.

The findings of this study revealed that 1) whether mandated or not, participatory decision making results in a higher degree of commitment by all constituencies, 2) commitment while not guaranteeing success, increases the likelihood of an initiative such as performance based funding improving student performance, 3) an emphasis on accountability shifts the focus to student success and removes barriers to completion, 4) community colleges continue to be under-funded while expected to provide services to meet growth and diversity demands and, 5) leadership is key to the success of any participatory decision-making initiative. This study suggests that additional research is needed to investigate implications of leadership and external influences. 


\section{DEDICATION}

This dissertation is dedicated with all of my love to my family for teaching me all I need to know about life.

My parents, Tom and Mickey, for teaching me the value of hard work, integrity, and the meaning of true love.

My brother, Tom, for teaching me that real courage is persevering regardless of the obstacles one meets along the way.

My brother, Jimmy, for teaching me that the human spirit lives forever. And, most importantly, for giving me the inner strength and faith to always endure (1956-1977). You are missed but never forgotten. 


\section{ACKNOWLEDGEMENTS}

A project of this magnitude could not have been completed alone. My heartfelt thanks and appreciation

\section{To My Dissertation Committee Members:}

Dr. Paula A. Cordeiro, my Committee Chair for her guidance, patience and commitment to teaching and leadership. Dr. Cordeiro is simply the finest advisor and mentor a doctoral student could have. Dr. George R. Boggs, a leader committed to shared governance, for his support and encouragement over the years while sharing his wisdom, Dr. William E. Piland, for his thoughtful comments and critical eye and Dr. Lonnie L. Rowell, for providing a wonderful example of teaching here and abroad. I am forever in their debt.

\section{To My Colleagues:}

The Professors at the USD School of Education who challenged me throughout this journey. My Palomar College colleagues, particularly the Business Education Department faculty and staff for their support and encouragement. Joan Blumeyer for her helpful editorial comments during the dissertation-writing phase. Christine Barkley for her editorial comments during the proposal-writing phase. The 
legislators, board members, presidents, administrators and faculty without whose generous gift of time and insights this study could not have been completed. And, Dr. Teresa Doyle, for making all of this possible.

\section{To My Friends :}

In particular, Dr. Candice Ann Francis without whom I doubt I would have survived the ordeal of this dissertation. I owe her a debt of gratitude for her editorial insights, support and occasional shoulder to cry upon. Also, thank you to my friends and extended family that I have neglected especially George, Barbara, Diane, Ellen, Mary, and Resa. Thank you all for always supporting and believing in me. And, Dr. Carol Young for taking care of my body so that my mind could complete this journey.

\section{To My Students :}

Past, current and future for constantly teaching me more than I could ever imagine to teach you.

\section{To The "Kids":}

Jason, Melissa, T.J., Thom and Riley who represent my legacy. My love always. 
TABLE OF CONTENTS

CHAPTER 1: STATEMENT OF THE ISSUE ............... 1

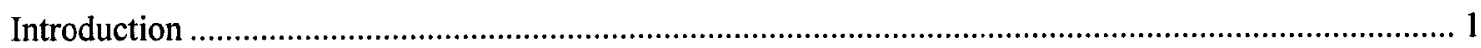

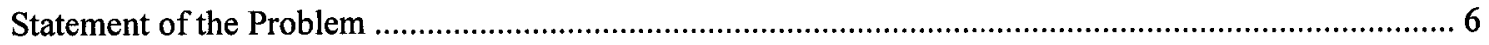

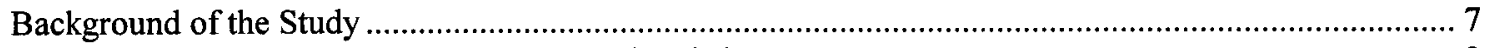

California's Community College System (CCCS) ……................................................................. 9

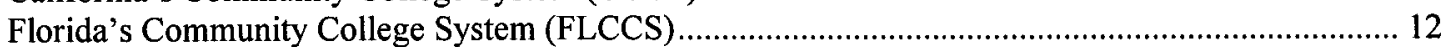

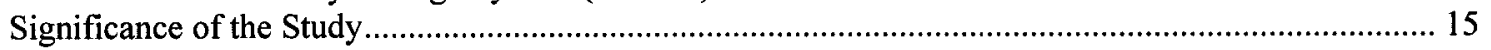

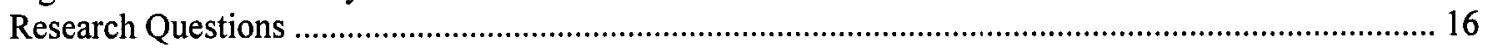

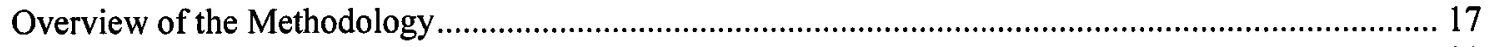

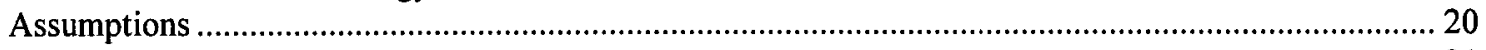

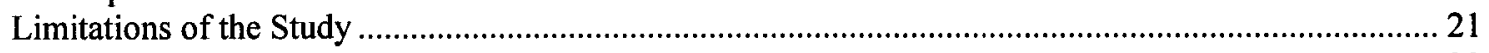

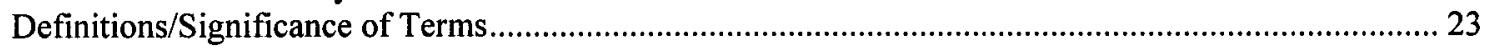

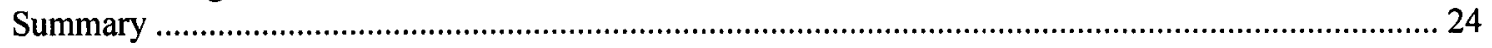

CHAPTER 2: REVIEW OF THE LITERATURE ............. 25

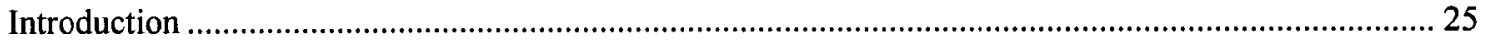

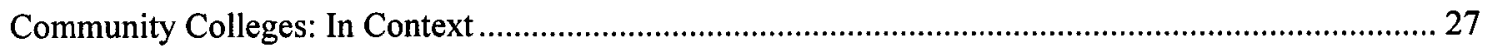

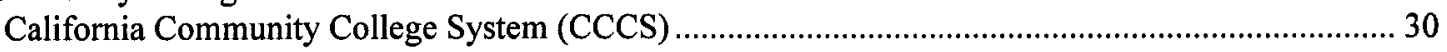

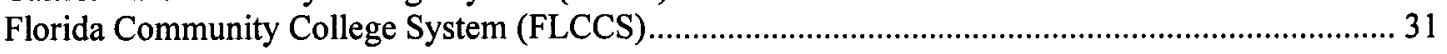

League for Innovation in the Community College ................................................................................. 32

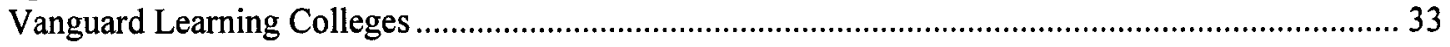

Community College Decision-making Models ........................................................................... 35

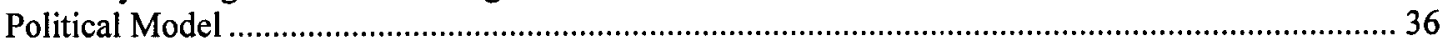

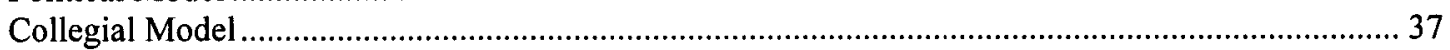

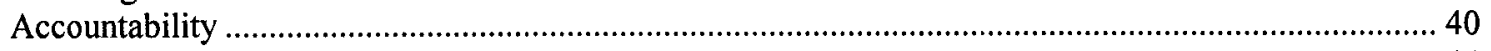

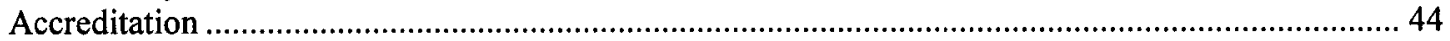

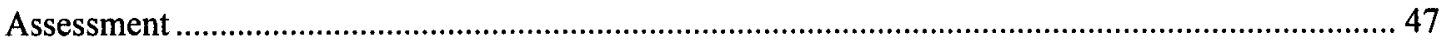

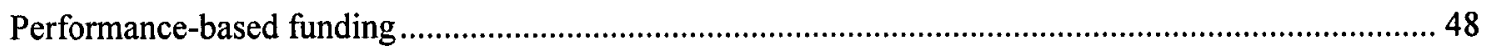

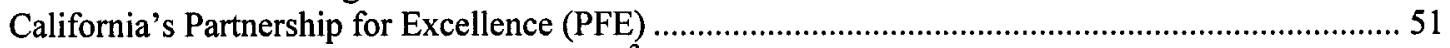

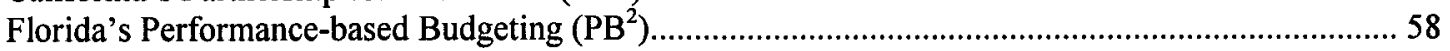

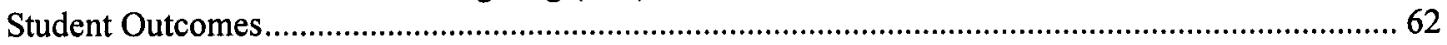

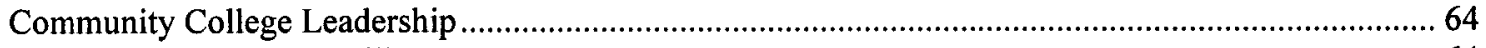

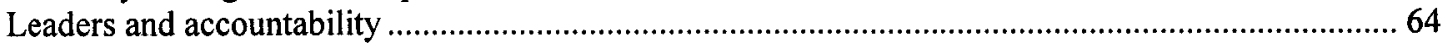

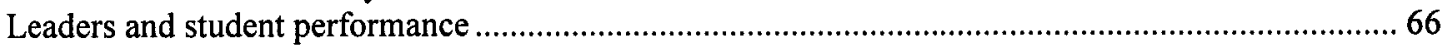

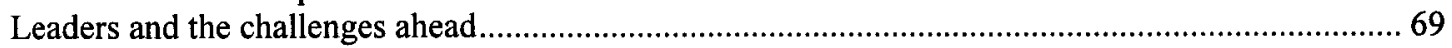

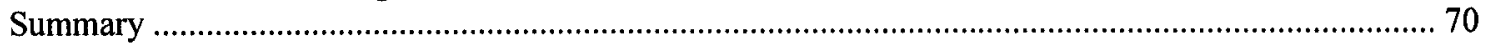

CHAPTER $3:$ METHODOLOGY ........................ 75

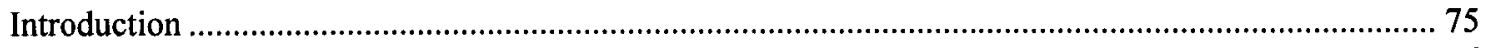

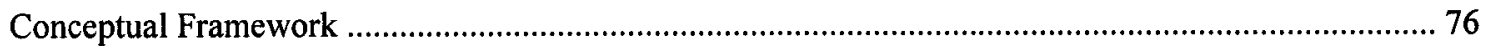

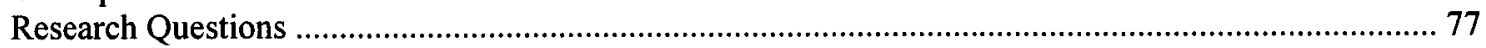

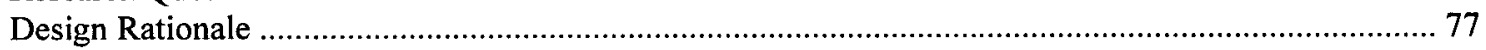

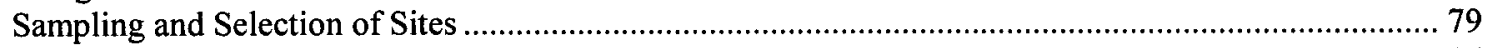

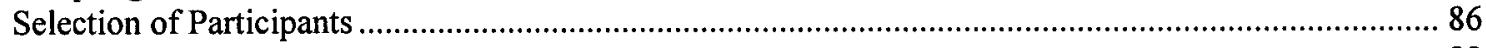

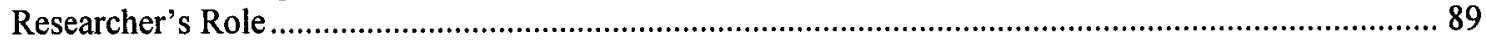

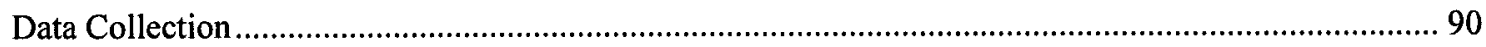

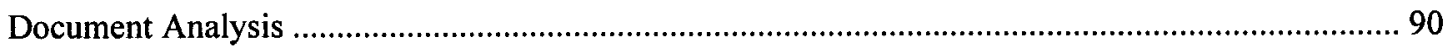

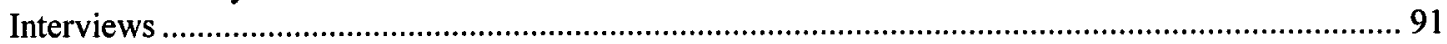

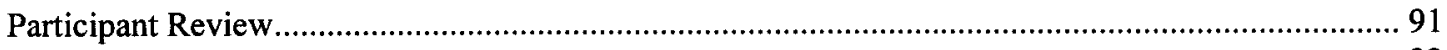

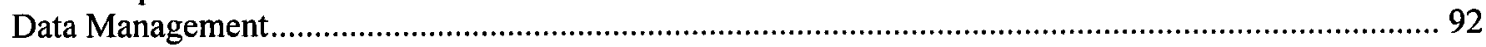




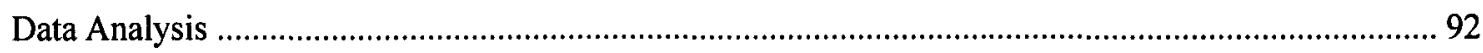

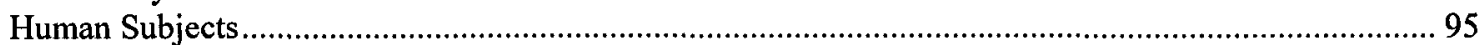

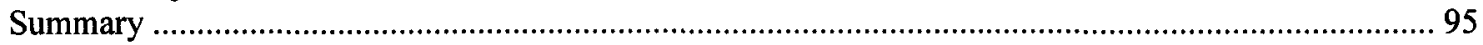

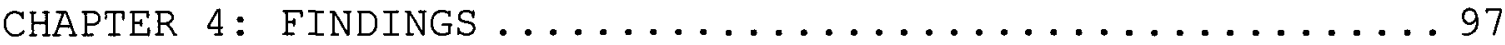

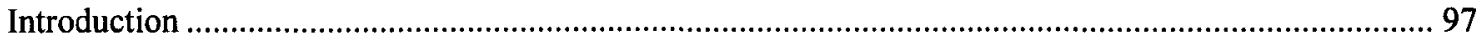

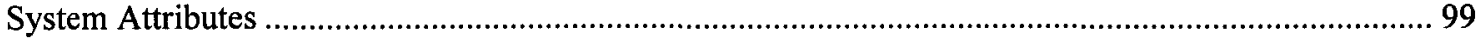

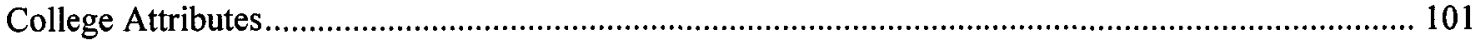

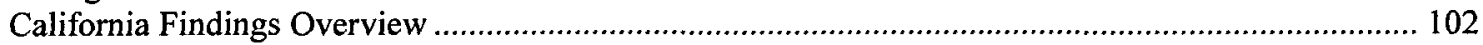

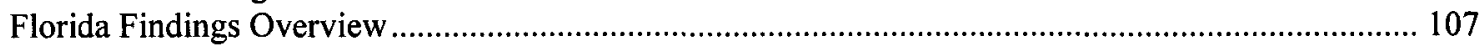

California System Interview Data ..................................................................................................... 109

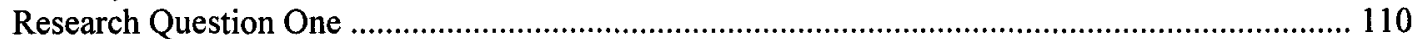

Research Question Two ........................................................................................................... 114

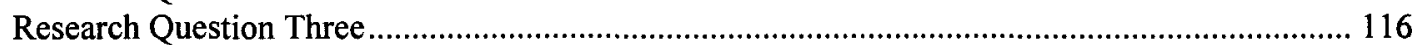

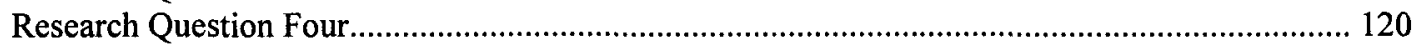

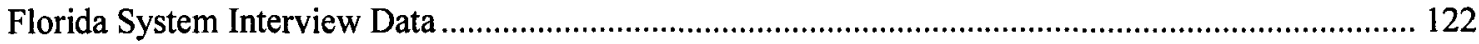

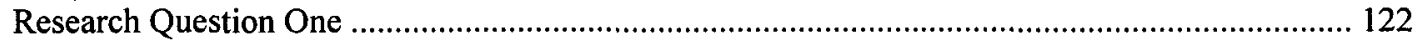

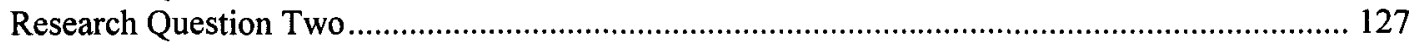

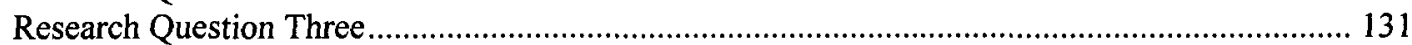

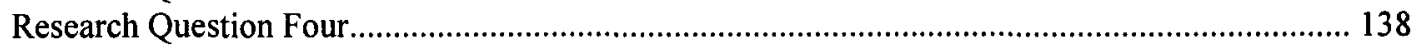

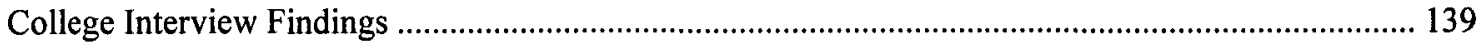

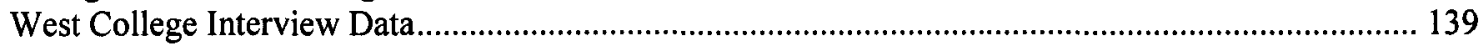

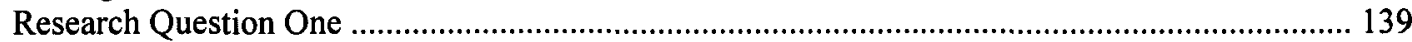

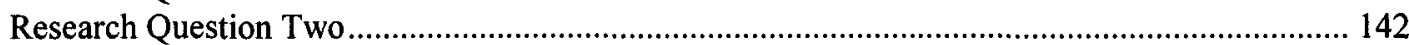

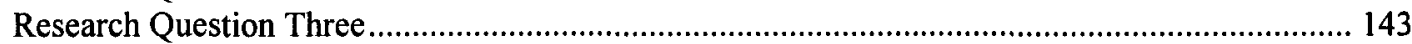

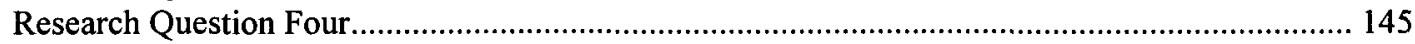

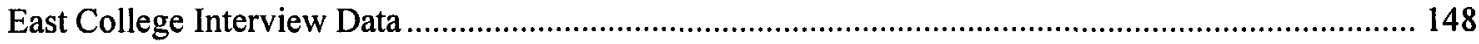

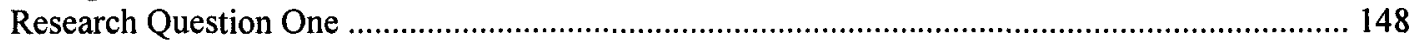

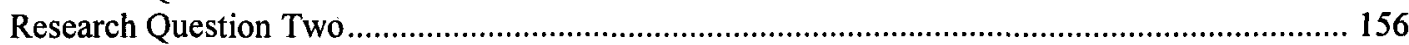

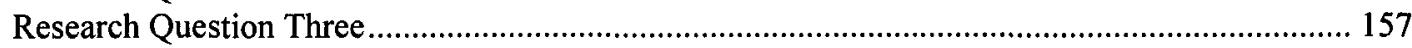

Research Question Four........................................................................................................ 159

An Analysis of California's and Florida's Systems and Colleges by recurring themes ......................... 161

California System Themes................................................................................................................... 163

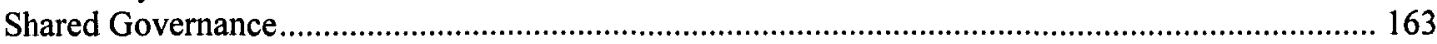

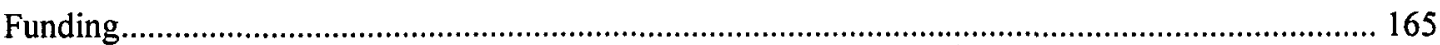

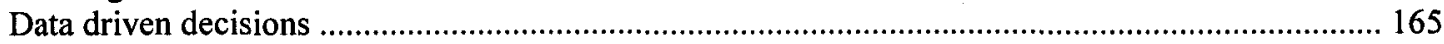

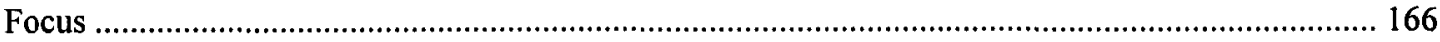

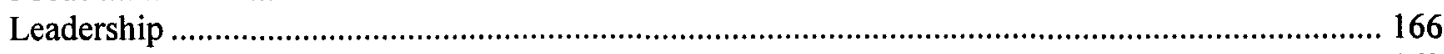

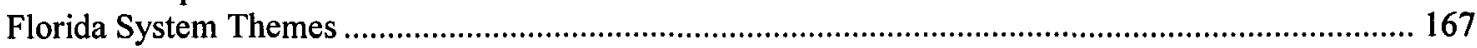

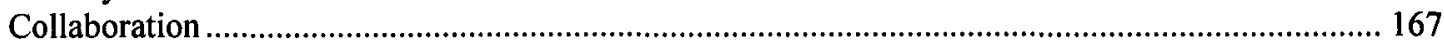

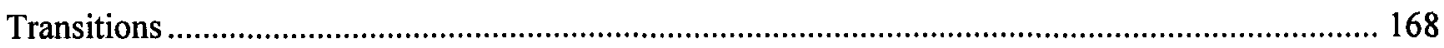

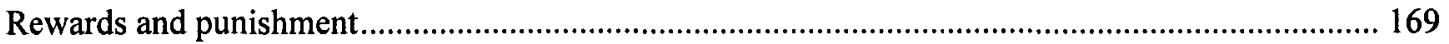

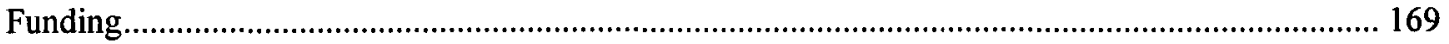

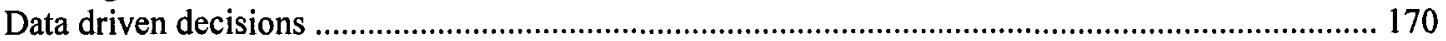

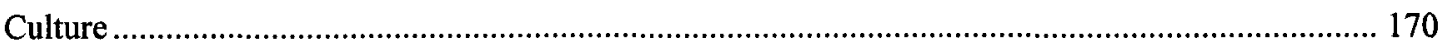

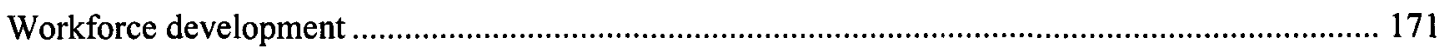

West College Themes................................................................................................................ 172

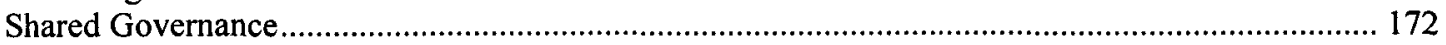

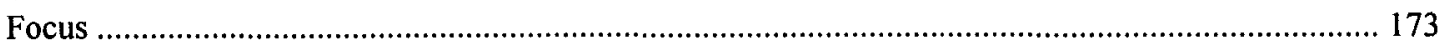

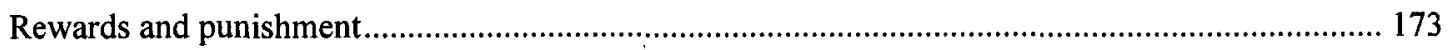

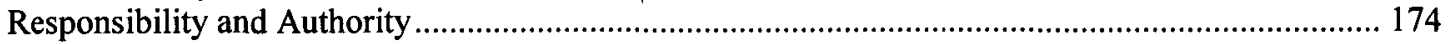

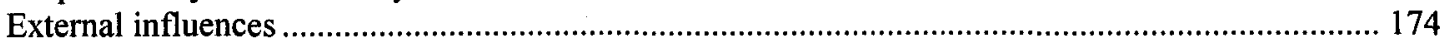

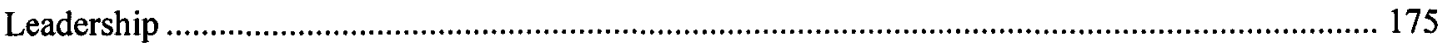

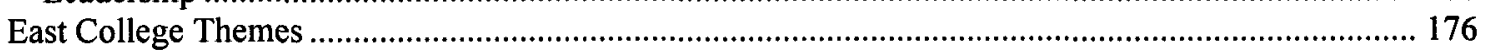

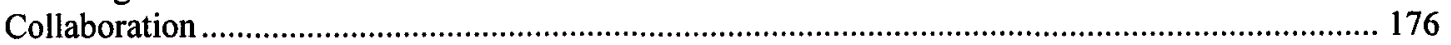




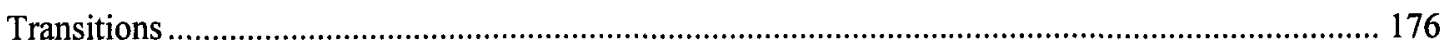

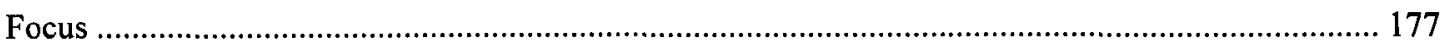

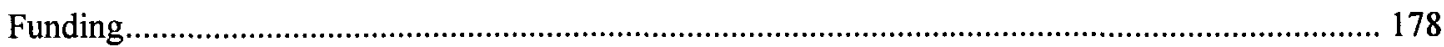

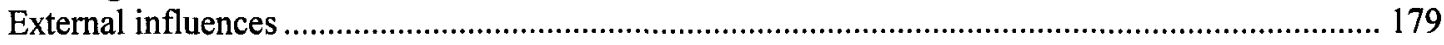

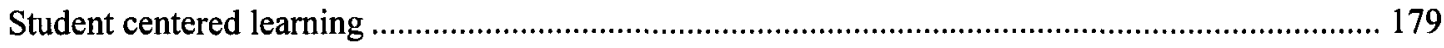

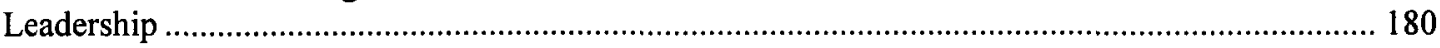

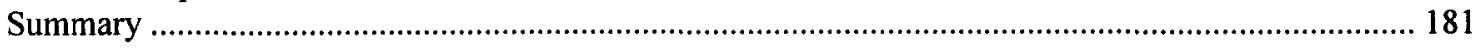

CHAPTER 5: DISCUSSION, IMPLICATIONS AND RECOMMENDATIONS . 186

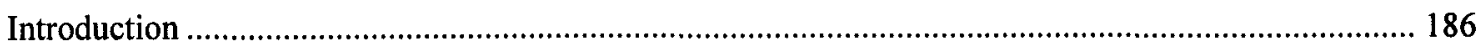

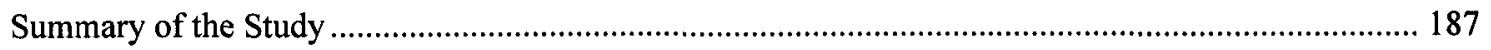

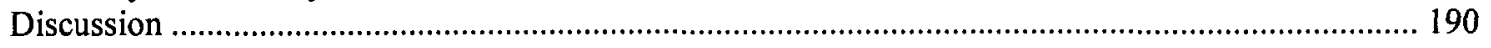

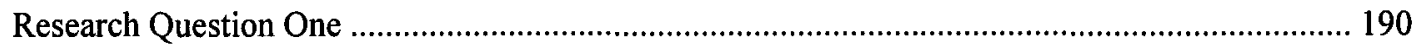

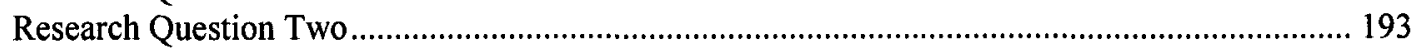

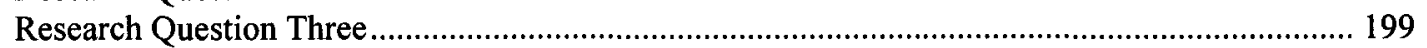

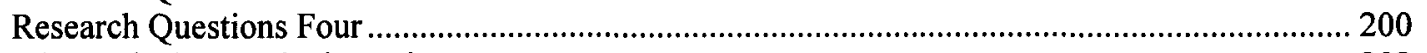

Related Conclusions and Discussion ............................................................................................ 202

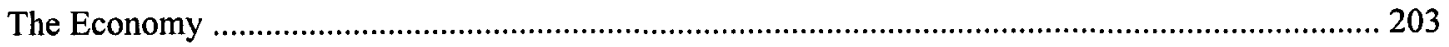

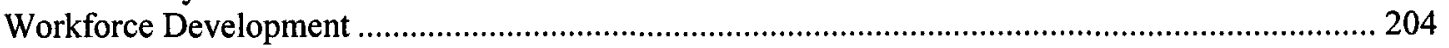

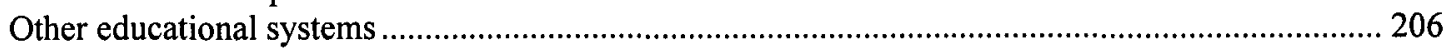

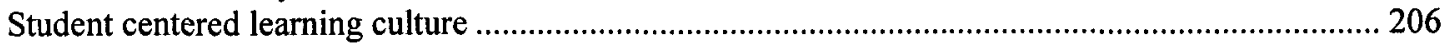

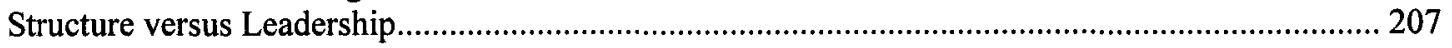

Implications for Leaders and Policymakers................................................................................... 210

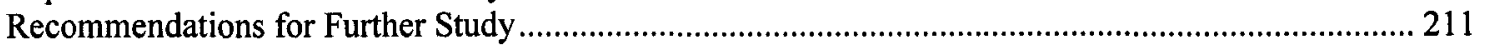

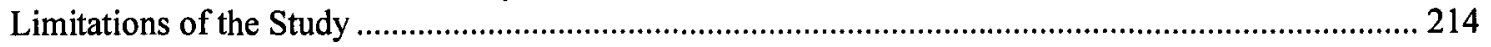

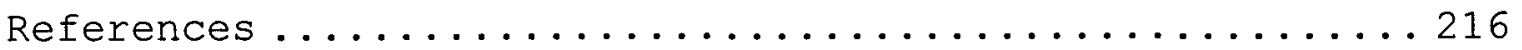

Appendices ............................. 226 


\section{IIST OF TABLES}

Table 1: Participant Identifiers.............. 88

Table 2: System Attributes ................. 99

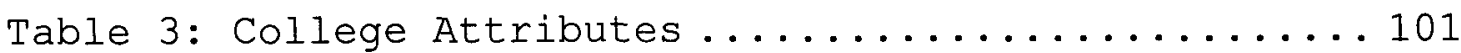

Table 4: Comparison of system and college findings.... 162 


\section{LIST OF APPENDICES}

Appendix A: Letter of Introduction ............. 227

Appendix B: Consent Eorm (State/System) .......... 228

Appendix C: Consent Form (Local/College) ........... 229

Appendix D: Interview Guide \#1

(State/System Participants) ............230

Appendix E: Interview Guide \#2

(Local/College Participants) ............ 232

Appendix F: Document Review Analyzer............ 235 


\section{CHAPTER 1: STATEMENT OF THE ISSUE}

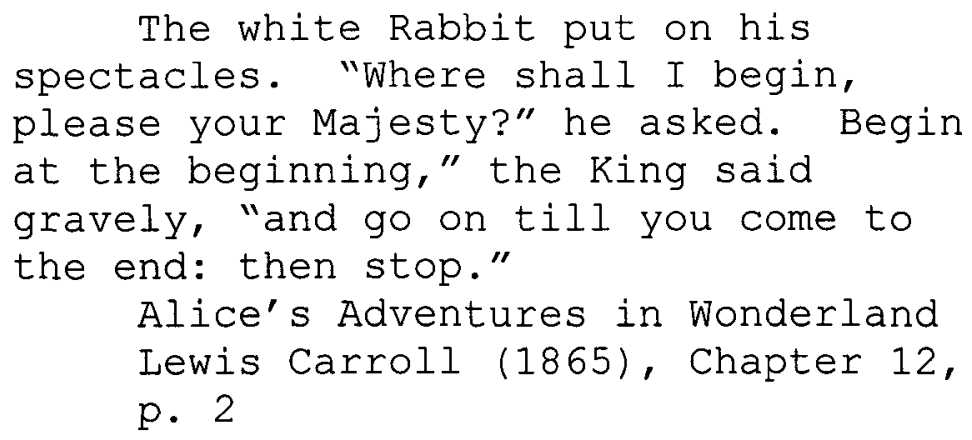

\section{Introduction}

Community Colleges as educational institutions began in the early $20^{\text {th }}$ century and one hundred years later they continue to serve the nation. There are approximately "1,100 community colleges, technical colleges, two-year branch colleges, tribal colleges, and independent junior colleges in the United States" (Vaughan, 2000, p.1). Many similarities exist in all of these institutions regardless of their location or size. One primary similarity is the mission of all community colleges, which is shaped by a commitment to open-access, community-based learning, and lifelong learning (Vaughan, 2000, p. 3). However, the decision-making process used to govern each community college is as unique as the communities in which the colleges exist. 
According to Vaughan (2000), "In the academic world, governance is the process through which institutional decisions are made" (p. 20). According to Bush (1995), a collegial model emphasizes a process whereby decisionmaking is shared (p.53). Most community colleges have formal and informal organizational structures where committees, college-wide forums and councils representing various segments of the college community enhance the governing process. This collegial governance process is considered by many as the most appropriate way to manage a college (Bush, 1995, p.53). Some states, such as California, have legislated a "shared" governance model, which defined the decision-making process to be used at the system and local level. In addition, legislators and the public throughout the nation have demanded that accountability standards within education be developed and be tied to funding. According to Bush (1995), "the desire to maintain staff participation in decision-making may conflict with the pressure to become increasingly accountable to external funding and quality control bodies (p. 56). Therefore, the impetus for undertaking this study is to identify the relationship between decisions made using a shared or participatory decision-making process and attempts to create and achieve accountability measures. The 
researcher contends that shared decision-making processes have been created without a system-wide understanding of what shared decision-making is and agreement on how it is done. It is further believed that competing goals regarding decision-making outcomes directly impacts an organization's ability to initiate and achieve accountability standards. According to Miller (1999), there are three primary factors contributing to a group's ability to make decisions: group processes and communication, group leadership, and organizational influences (p. 31). Several researchers who have studied governance in community colleges (CCCT, 1989; Deas, 1998; Giese, 1996; Trombley, 1997; Vaughan, 2000) believe an effective governance process requires a commitment from the entire leadership to participation, collaboration, teamwork and consensusbuilding skills. Moskus (1999) contends individuals feel empowered when they participate. The Little Hoover Commission, an independent state oversight agency convened to examine the California Community College system, released the report, Open Doors and Open Minds: Improving Access and Quality in California's Community Colleges in March, 2000. According to the report, if California's Community Colleges intend to respond to the diverse needs and learning styles of potential students, there must be "a 
governance model that provides leadership and accountability both from the top down and from the bottom up" (p. xiii).

Therefore, the purpose of this study is to examine the impact of governance as reflected in how decisions are made, whether shared by legislative mandate or by convention, on attempts to institute accountability measures in two states with comprehensive community college systems. A further objective of this study is to compare two community college systems' models of governance to illustrate how the decision-making process used impacts a performance-based funding program in each state. The two state community college systems chosen were California and Florida. The study analyzes the decision-making governance model of the California and Florida community college systems at the state and local level. It further analyzes California's Partnership for Excellence (PFE) and Florida's Performance-Based Program Budgeting $\left(\mathrm{PB}^{2}\right)$ in an effort to determine if any evidence could be found to suggest that the type of governance process used in each system impeded or advanced the formation and implementation of either accountability program.

The case study approach was used to analyze the process and outcomes for each state's community college 
system at the local and system level. According to Merriam (1998), "a case study is an examination of a specific phenomenon such as a program, an event, a person, a process, an institution, or a social group" (p. 9). "The bounded system, or case, might be selected because it is an instance of some concern, issue, or hypothesis." A case study presents a "snapshot" view of a problem (Merriam, 1998, p. 10). Therefore, this study looks at governance and accountability tied to funding primarily during the year 2000. Conducting a case study analysis allowed for an indepth exploration of the issues related to decision-making and accountability efforts for each system. Furthermore, a cross-case comparison allowed for the identification of common issues and concerns. According to Merriam (1998), comparing sites or cases, allows the researcher to establish a range of generalities of a finding or explanations while pinning down the conditions under which the findings occurred. (p.154)

This chapter defines governance, accountability and performance funding for purposes of this study. It states the problem and provides background regarding the two states under review. In addition, an overview of the study has been provided, and the research questions identified along with a brief description of the methodological 
approach. Finally, assumptions and limitations of the study have been introduced in this chapter.

\section{Statement of the Problem}

Accountability concerns and performance-based funding issues in public higher education have touched almost every region of this nation. Many states previously using program-based funding formulas in their budgeting and resource allocation processes have supplemented such formulas with productivity measures and other accountability techniques to evaluate institutional performance and to allocate resources (Honeyman, Wattenbarger \& Westbrook, 1996). Additionally, accreditation agencies appear to have an increased focus on accountability in the accreditation process. Currently, there are six regional accrediting commissions that set standards to improve higher education throughout the country. According to the Southern Association of Colleges and Schools (SACS), a regional accrediting commission, member institutions are expected to have governance and administrative structures appropriate to higher education and adequate financial resources (SACS website, 2000).

Stability and security are crucial to institutional well-being, as are effective resource procurement, deployment, and accountability. Academic self-governance, a time-honored value, implies broad participation 
in policy-making and implementation (Section VI of SACS website, 2000).

Therefore, the overarching problem under investigation in this study is to determine how governance, whether shared by legislative mandate or by convention, affects accountability in two states with comprehensive community college systems. A further objective for this study is to compare both systems' models of governance and illustrate how the decision-making process has impacted a performancebased funding program in each state.

\section{Background of the study}

To address concerns regarding accountability, California created the Partnership for Excellence (PFE) for the community college system and Florida, the PerformanceBased Program Budgeting $\left(\mathrm{PB}^{2}\right)$ for all government agencies, including the community college system. The California legislature codified and funded PFE in its 1998-99 state budget. PEE was developed through the consultation process as legislated by Assembly Bill 1725 (AB1725) in 1988 . AB1725 was a landmark legislation designating the California Community Colleges as a system with eight major areas addressed in the bill, including a legislated consultation process that mandated shared governance at the system and local level. Simply stated, this consultation 
process or shared governance is the sharing of power in a decision-making process in a climate of mutual trust (Baca, 1998; CCCT, 1989; Deas, 1998; Francis, 1990). Utilizing the consultation process, the state Chancellor proposed and the state Board of Governors (BOG) adopted the PFE goals and measures. According to the Little Hoover Commission (2000), "PEE is a step toward performance-based budgeting" (p. 18). California's PFE program is specific to the state's community college system, and represented a systemwide effort to achieve specific accountability goals addressing student performance outcomes.

Florida, on the other hand, has been in the national forefront in bringing performance measures into the budget process to make funding decisions throughout its various state government agencies (OPPAGA, Performance-Based Program Budgeting in Context: History and Comparison, 1997). In 1994, the Florida legislature enacted the Government Performance and Accountability Act, which established the Performance-Based Program Budgeting ( $\left.\mathrm{PB}^{2}\right)$ throughout the state government to be phased in over a seven-year period. During the fiscal year of 1996-97, Florida community colleges began to operate under the $\mathrm{PB}^{2}$ model. Florida's $\mathrm{PB}^{2}$ emphasizes the connection of funding to accountability measures with the understanding that if 
"an accountability system is to be relevant, it must be tied to budget decision-making" (OPPAGA, Performance-Based Program Budgeting in Context: History and Comparison, 1997, p. 19). In contrast to California, Florida does not have legislatively mandated shared governance. $\mathrm{PB}^{2}$ was established by legislative statute and implemented in the community college system by the state Board of Community Colleges and the local boards of trustees.

\section{California's Community College System (CCCS)}

According to Bogue (2000), American higher education is a system with "complex governance structures in which lay boards of trustees play an important and critical role, an organization in which collegial/consensus principles of organization contend with hierarchical/bureaucratic organizational principles" (p. viii). In 1921, California's legislature passed the Junior College Act, the first in the nation, which supported the operation of locally governed junior college districts independent of public high schools (Vaughan, 2000, p. 32). The CCC system currently consists of 108 colleges operating as 72 community college districts.

In 1988, the state of California attempted to deal with its complex governance structure and define the role of community colleges in higher education through the 
passage of Assembly Bill 1725 (AB1725), which established the community colleges as a system separate from the $\mathrm{K}-12$ system. The California Community College system underwent intensive scrutiny and evaluation during the mid-to-late 1980s, first by the Commission for the Review of the Master Plan for Higher Education and then by the Joint Legislative Committee for Review of the Master Plan. The outcome of the evaluation was the creation of the community colleges "reform bill," Assembly Bill 1725 (Chapter 973, Statutes of 1988). This legislation mandated a shared decision-making process later identified as "shared governance" along with a requirement that a comprehensive educational and fiscal accountability program be developed and implemented for the California Community College system. However, in a report issued in 2000 by the Little Hoover Commission, California's state and local governance structures, as well as the state's funding procedures, were found to be lacking with regard to creating or supporting accountability. During the $1990^{\prime} \mathrm{s}$, several quantitative and qualitative studies, reports and journal articles examined the effects of AB1725 on the governance of California Community Colleges (Flanigan, 1994; Francis, 1990; Giese, 1996; Howell, 1997; Sims, 1998; Trombley, 1997; Wirth, 1991). On April 15, 1997, the California Citizens 
Commission on Higher Education invited a wide range of leaders to participate in a roundtable discussion focusing on the impact of the AB1725 reform legislation in an effort to ensure that the community college system be efficient and responsive to the changing statewide demands. A wide array of individuals representing trustees, senior administrators, faculty, staff, faculty collective bargaining associations, and citizens' commission members participated in focused question discussions. The California Citizens Commission on Education reported,

AB1725 is widely regarded as a successful coalition-based bill, put together by groups inside and outside the community colleges, with the Board of Governors acting as a player but not unilaterally imposing reform. On the other hand, the finance and regulatory context created to implement the bill has critics on every side. Most criticism has been leveled at the impact of finance on access, at local governance and decision-making, especially the elaborate rights of faculty, staff, and students to participate so extensively in governance. (1997, p.7)

The Roundtable participants addressed each of the identified issues and their observations revealed among other things, that the CCC funding levels were inadequate and that "incentive funding is unlikely to gain support if it is imposed without collaboration between the state and those in the institutions" (Through the Looking Glass: The California Community Colleges as Seen Through AB1725, 1997, p. 7) 
In an effort to improve quality, through an initiative of the Board of Governors (BOG), the Partnership for Excellence (PFE) was codified and funded in the 1998-99 state Budget. The PFE program represented California's attempt to connect community college funding to accountability goals and measures. The initial accountability goals for the PFE program consisted of improvements in the areas of transfers, degrees and certificates, successful course completion, workforce development, and basic skills improvement with other goals under consideration for inclusion (SB1564, SEC. 35, Section 84754, 1998). The goals were established for the system as a whole but were dependent upon the individual actions of each district. Based upon the combined efforts toward the five system goals, if reasonable progress was made, PEE would continue to be funded; however, if the state fulfilled its investment commitment but the system made little or no progress towards attainment of the goals, the BOG was authorized to take further action to assure system accountability.

\section{Florida's Community College System (FLCCS)}

In a survey conducted by Moak (1999) entitled $\underline{A}$ View

From the States: A Survey of the Collection and Use of Cost Data by States, it was reported that many state 
legislatures require accountability and performance measures linked to costs and revenues: "every state collects higher education cost data, but there are variations as to which state agencies collect the data, when data are collected, how data are used, and the level of detail at which data are collected" (p. 14). The survey results indicated that all 50 states used cost data for state budget appropriations and some used it in funding formulas, in productivity/performance measures, faculty salary setting, peer analysis, tuition setting, and academic or other program reviews. Florida uses this cost data for all of the criteria listed above except tuition setting. Florida's system was established in 1983 by state legislators consisting of 28 locally controlled community colleges. A State Board of Community Colleges consisting of 13 members including the Commissioner of Education, an elected official was established to oversee the entire system. (Florida website, 2000, General Information: Education) .

Florida initiated the Performance-Based Program Budgeting $\left(\mathrm{PB}^{2}\right)$ when the legislature enacted the Government Performance and Accountability Act in 1994, which phased in all government agencies over a seven-year period. Community colleges began to operate under $\mathrm{PB}^{2}$ during the 
1996-97 fiscal year. The law mandated that the program address degree graduations, minority enrollment and retention, student performance, job placement and student transfer (Florida Community College System, 2000, p. 3). Minnesota, North Carolina, Iowa, Texas, and the federal government all use program performance information for resource allocation decisions in education, but Florida's $\mathrm{PB}^{2}$ initiative was considered among the most ambitious Performance-Based Program Budgeting in Context: History and Comparison, 1997, p. ii). It appears the Florida legislators chose performance-based budgeting because this approach considers how well funds are being used to achieve desired goals, and it offers lawmakers information to assist in assessing funding needs for competing resources. $\mathrm{PB}^{2}$ is seen primarily as an accountability tool requiring individual colleges to submit data on an annual basis for review and evaluation based on attainment of specific accountability measures.

Florida's $\mathrm{PB}^{2}$ evaluates colleges and districts on an individual basis, whereas California's evaluation is system-wide based on the success of the entire system to achieve outcome goals. Another primary factor distinguishing Florida's PB $^{2}$ from California's PFE program is the governance process under which each was created. 
California's mandated shared governance model stipulated the creation of an accountability program. In contrast, Florida, which does not operate under mandated shared governance, underwent a complete review during the 2001 Legislative session as a result of a student-centered governance model adopted in 2000 which draws decisionmaking back to what they define as the core purpose of education. The student-centered model reinforces the need for accountability for decisions at every level of student learning: classroom, administrators, appointed board members, elected officials and the community based on criteria established in legislation. (Florida State Website, 2000, Glossary of Terms and Acronyms, question \#4). "For the first time in Florida's modern political history, those in education - elected or appointed - must be and can be judged on their commitment to quality education" (Florida website, Frequently Asked Questions, 2000, question \#4).

\section{Significance of the Study}

This study was designed to further research on the relationship between the decision-making processes used to govern community colleges and the success of accountability initiatives tied to funding in an attempt to provide an empirical basis for assessing what relationships need to 
exist between governance and accountability in a community college system. Additionally, this study attempts to identify whether or not participatory decision-making, as supporters contend, increases the commitment of an organization to a decision outcome. In addition, because this study examines the impact of governance in establishing goals and objectives in the development and implementation of accountability initiatives, it is expected that this inquiry will provide meaningful research about the relationships between governance and accountability that was noted as being currently absent in the literature. Finally, the union of college and state level data and document review, as described in this proposal may provide a rich source of information upon which community colleges may draw in an effort to respond to the growing demand for educational accountability through increased student performance outcomes.

\section{Research Questions}

No studies were identified which delineated or clarified the relationship between governance and accountability or the impact of the decision-making process used to govern community colleges on any attempts to implement an initiative connecting funding to 
accountability measures; therefore, the research questions addressed in this study were as follows:

1. What is the governance or decision-making process used for community colleges in each state as described by key stakeholders?

2. What effect, if any, did the governance process have on the development of the accountability measures and performance-based funding initiatives currently in existence ( $\mathrm{PFE}$ in California and $\mathrm{PB}^{2}$ in Florida) as perceived by key stakeholders?

3. What differences, if any, exist within each state's governance process to indicate any possible impact on how each state is addressing accountability and performance-based funding?

4. How has each states' governance process impeded or advanced the formation and implementation of the performance-based funding process (PFE in California and $\mathrm{PB}^{2}$ in Florida) as perceived by key stakeholders?

Additionally, the following sub-research question was inherent in each of the above questions: How, if at all, do these perceptions differ at the state (system) level from the local (college) level?

\section{Overview of the Methodology}

A case study approach was used to analyze the process and outcomes of adopting shared decision-making procedures in a community college system particularly with respect to accountability efforts. The research questions were exploratory, descriptive and explanatory in nature. Exploratory studies seek to answer research questions by linking answers to related patterns, themes and categories. 
Descriptive studies describe phenomenon being studied according to common behaviors, events, attitudes, structures and processes. Explanatory studies ask how events and policies interact. Therefore, while the study describes the situation of both states, it also attempts to explore commonalties in an attempt to explain the relationship between decision-making and accountability.

The states of California and Florida were used for this study with one college from each state included in the evaluation. The unit of study included the CEO, faculty members primarily those serving in faculty leadership roles, administrators and a trustee at the local level. At the state level, the Chancellor or Executive Director of the state system and some key internal and external leaders were included.

The two colleges chosen for the study were selected because of similarities and shared interests. In 2000 the League for Innovation in the Community College, selected both colleges as Vanguard Colleges. Vanguard Colleges are a select group of national colleges identified as particularly committed to improving student learning. Additionally, both colleges underwent a change in presidential leadership following a predecessor who had served for an unusually long period of time as president. 
Student enrollment is similar at each college and each operates as a single college district with multiple locations throughout its community district. At the inception of the study, a union did not represent faculty at either institution. However, the California college faculty has since unionized.

The researcher was the research instrument. Information was gathered via document examination and by conducting interviews. The documents included minutes of campus-wide meetings, reporting documents and policy statements. Documents were analyzed for content by using a document analysis instrument (Appendix F). Interviews were conducted with key stakeholders such as: governing board members, CEOs, faculty currently or previously serving in leadership positions and senior administrators.

Interview transcripts and documents were analyzed inductively to discover common themes, patterns and definitions, and the analysis was related back to the research questions. QSR NUD*IST N5 software for qualitative data analysis was used to analyze the research data. The research design and methodology were flexible. Responses and events at each site resulted in follow-up questions due to the evolutionary nature of case study research. 
Individual interviews were confidential and direct quotes used only with permission. The degree of confidentiality maintained in reporting the findings was discussed with the participants at the time of the interview. Any documents reviewed were public documents and were used without seeking further permission to do so.

\section{Assumptions}

Several assumptions underlie this study and guided the development of the research questions and design. They include: an initial assumption that shared decision-making requires the involvement of administrators, faculty and staff in a participatory governing environment. A second assumption was that a participatory process of governance is desirable for the success of any higher education organization whether it is legislatively mandated or not. A third assumption made was that community colleges are interested in developing and achieving levels of accountability particularly with regard to student performance outcomes.

In addition, the researcher assumed that those interviewed were truthful about their perceptions and that they would recall and report accurately their attitudes and recollections of their experiences related to shared 
decision-making and accountability efforts to improve student performance outcomes.

Finally, dynamic systems and colleges are continually evolving; however, this case study represents a snapshot of a specific point in time. Several major changes occurred at both colleges and in both states studied during and since the initiation of the research. Since inception of the study, both colleges experienced leadership transitions. Faculty of the California College voted to unionize while the Florida state legislators chose to overhaul the governance process throughout its entire education system affecting every college within the system. Therefore, some limitations are inherent.

\section{Iimitations of the Study}

Qualitative inquiries must meet tests of rigor in order to establish trust in the outcomes of a study (Guba \& Lincoln, 1985). Attempts were made to ensure credibility, accuracy and dependability of the study through triangulation of data, through the methods used and the breadth of participant's interviews in the study. Trustworthiness may have been compromised because of the researcher's inexperience and limited resources; however, every effort was made to ensure neutrality. Neutrality is established by the degree to which findings are a function 
solely related to the data and not of the biases, motives, interests and perspectives of the researcher (Guba \& Lincoln, 1985). An audit trail was maintained including audio transcripts, raw data assessment, data reduction techniques used, journal reflections and other documents to support the study. Additionally, every attempt was made to control for researcher bias through the use of thick descriptions, which consisted of literal descriptions of the circumstances and characteristics of the two states and colleges studied (Guba \& Lincoln, 1985). The researcher also attempted to control biases through a thorough analysis of documents and semi-structured interviews; however, because only two colleges were selected for this study the findings created some insight into two state systems but certainly cannot speak to the whole system within each state.

Additionally, it is acknowledged that the two colleges selected for this study may in fact be outliers and the data obtained during this inquiry may not be transferable to other community colleges. Because each state system possesses unique or extreme aspects with regard to governance or performance-based funding, this study will only be transferable to community colleges with similar governance and performance-based funding programs tied to 
accountability measures associated with similar student performance outcomes. Finally, the researcher submits that no two colleges have the same style, employ the same methods or ever interpret shared decision-making the same way. Therefore, isn't accountability very much tied to the leader's style and his/her interpretation of shared decision-making?

\section{Definitions/Significance of Terms}

The following definitions apply for purposes of this study:

Governance refers to the decision-making process used to govern a community college whether at the state or local level.

Participatory decision-making refers to the process whereby leaders consult with the various constituents for their input before making decisions.

Accountability refers to the measurement of actual student performance outcomes against expected outcomes to determine overall effectiveness. Such as, number of degrees conferred, transfers, etc.

Performance Funding refers to supplemental funding tied to specific performance outcomes. 


\section{Summary}

When participatory decision-making processes are clearly defined and parameters of usage established, shared decision-making may enhance a community college's ability to achieve accountability standards. No research has yet been published on this relationship. This case study analyzed the dynamics involved in an environment of shared decision-making and its effects on achievement of accountability standards in a community college organization. It also demonstrates possible areas for further research on the impact of shared governance on accountability initiatives in a community college at the system and local level. 


\section{CHAPTER 2: REVIEW OF THE IITERATURE}

The review of the literature is perhaps the single most important section of a dissertation proposal, even though many ABDs see it as something you "tack on" when the real work is finished. In truth, a properly executed critical review of the literature lays the foundations from which the rationale for the study, statement of the problem and hypotheses, and design of the research emerge.

How to Complete and Survive a Doctoral

Dissertation David Sternberg, Chapter 4, p. 92-93

\section{Introduction}

This chapter provides a broad review of the literature concerning attempts by two community college systems to address issues of accountability tied to student performance outcomes in an environment of participatory decision-making. In the course of this study, four primary areas of the literature emerged as relevant to this review. The chapter begins with a historical perspective of the community college system of both states. This is followed by a discussion of the types of decision-making models used in each state to govern community colleges. Then accountability efforts as measured by student performance outcomes are addressed. And finally, a discussion of the types of supplemental funding models tied to student 
performance outcomes. The literature review has been organized around these four broad areas and is presented according to their relationship of one to the other. Presented first is a historical view of the community college systems in the two states under examination. This is followed by a discussion of the different models of decision-making generally used in an academic environment including a more in-depth discussion of the role of participatory or shared governance in both states under review. Finally, literature is presented regarding accountability as it relates to student performance outcomes and areas of supplemental funding tied to specific performance objectives. The task of identifying relevant literature was a difficult one considering the nature and broad scope of the issues under investigation. One particularly noteworthy deficiency identified during the review of the literature is the absence of literature addressing whether or not there is a relationship between shared or participatory decision-making and attempts at improving student performance outcomes.

Sources for the literature reviewed in the course of this study were primarily through the use of computer search services of the Educational Resources Information Center (ERIC), LEXIS-NEXIS Academic. Reviews of 
Dissertation Abstracts as well as bibliographic references served as additional sources for relevant literature. Documents and services were obtained primarily through online library services provided by the University of San Diego and local community colleges. In addition, public records via Internet access of both States' websites and various publications and journals of the American Association of Community Colleges served as valuable resources in the course of this review.

\section{Community Colleges: In Context}

Community Colleges have served the nation for a little more than a century responding to the needs of their specific communities. The first and "the oldest continuously existing public two-year college in the nation," Joliet Junior College, was established in 1901 in Illinois (Vaughan, 2000, p.31). The mission of most community colleges includes a commitment to: open-access, providing comprehensive education programs, existing as a community-based institution of higher education, emphasizing teaching and learning and fostering lifelong learning (Vaughan, 2000, p.3).

The number of community colleges increased throughout the nation during the twentieth century. According to Phillippe and Valiga, 
By 1998 , there were 1,600 community colleges across all 50 states (including branch campuses). Of the 1,132 community colleges operating in 1998 (not including branch campuses), 968 were public, 137 were independent, and 27 were tribal" (National Profile of Community Colleges: Trends and statistics, 2000).

The number of community colleges in any one particular state varies from few to more than 100. The two states included in the study demonstrate this variation with one currently having 108 and the other 28 community colleges in their state.

Several significant events occurred over the 100 plus years that community colleges existed in the United States. In 1917, the North Central Association of Schools and Colleges was established for the accreditation of public and private junior colleges in an effort to standardize governing in such areas as admission policies, faculty qualifications, and minimum funding levels (Vaughan, 2000, p.32). California's Junior College Act of 1921 served as a model for other states in the development of junior college districts operating independently of public high schools. The first community college statewide governing board came to be in 1928 when Mississippi organized such a board to oversee its public junior colleges. Another significant development for the nation's junior colleges was the passage of the GI Bill of Rights in 1944, which provided 
financial aid for veterans of World War II. This bill helped to break down the economic and social barriers of attending college (Vaughan, 2000, p. 33). The President's Commission on Higher Education, which helped to popularize the term community college followed the GI Bill of Rights of 1947. In 1958, several states including California and Florida, with funding support from the W.K. Kellogg Foundation and Rockefeller family, introduced two-year associate degree programs in nursing. And, in 1968, the League for Innovation in the Community College was created to promote experimentation and innovation in community colleges. Then in 1978, California's Proposition 13, which restructured property tax allocation for education, signaled an increased demand from the public for greater accountability in public education.

Each of these events represented significant milestones in the history of national community college systems. However, in order to understand the complexity of the community college environment of each state, a brief overview of the community college systems under investigation are presented to help establish the context and setting for this study. The two systems under investigation are the California Community College System (CCCS) and the Florida Community College system (FLCCS). 


\section{California Community College System (CCCS)}

Established in the early twentieth century, the CCCS

is administered by the Chancellor's Office, which operates under the guidance of a Board of Governors. The state's Governor appoints the 16-member CCCS Board of Governors. The Board of Governors establishes policies and provides long-range planning and guidance to the 108 colleges in 72 districts that comprise the system. The Chancellor's Office and Board of Governors were created by legislation in 1967. The CCCS is the largest system of higher education in the world, currently serving 2.5 million students (California Community College Chancellor's web page, http://www.cccco.edu, September 8, 2002). Additionally, each of the 72 community college districts are governed by a locally elected Board of Trustees who are responsible for the operations of the college and responsiveness to local community needs.

In 1988, the California Legislature enacted AB1725 (Chapter 973, Statues of 1988), which reformed the CCCS governance. As a result of this legislation, the Board of Governors adopted a "consultation" process, through which a council of selected community college institutional and organizational groups assisted in the development and recommendation of policy to the Chancellor and Board of 
Governors. Such recommendations are then presented to the Legislature. This formal consultation process allows the massive community college system to participate in the governance of the system and advise the Chancellor, who makes recommendations to the Board of Governors on matters of policy. The Board of Governors then makes the final decision.

\section{Florida Community College System (FLCCS)}

Florida's first community college was founded in 1933 in Palm Beach. Since that time, the FLCCS has grown to 28 locally governed community colleges. The 28 community college districts are each governed by a Governor-appointed local Board of Trustees who is responsible for the operations of the college and responsiveness to local community needs. Until recently, the ELCCS was administered by the State Board of Community Colleges (SBCC), which was founded in 1983.

With the passage of House Bill 263 (HB263), the Elorida Education Governance Reorganization Act of 2000, community colleges will be coordinated under the jurisdiction of Florida's Board of Education as of January 7, 2003. HB263 established a Transition Task Force to administer this governance transition in a three-year phase-in. As a result of HB263, most state agencies 
governing education in Florida will no longer exist. The Florida Board of Education will consist of seven members appointed by the Governor. In effect, HB263 built a new governance model that provides for a seamless studentcentered education system, which values excellence while providing greater access and promoting academic success (http://www.MyFlorida.com/government, Education Governance Reorganization Transition Task Force, September 20, 2002). As a result of HB263, the Secretary of the Florida Board of Education will serve as the chief executive officer of Florida's K-20 education system. The Chancellor of the FLCCS, previously known as the Executive Director of FLCCS, is the chief executive officer of the community college system. The Chancellor reports to the Secretary of the Florida Board of Education. The Chancellor provides administrative support and guidance to the FLCCS. The legislated governance changes in HB263 reinforced the idea that accountability for the state's education systems rests with the highest elected official in the state: the Governor.

\section{League for Innovation in the Community College}

The League for Innovation in the Community College (League) is an international community college membership organization with more than 750 institutions from 11 
different countries. The League also partners with more than 100 leading corporations as well as other organizations, foundations, and government agencies bringing innovative ideas to all of the League's members. According to the League's website, it is the "only major international organization specifically committed to improving community colleges through innovation, experimentation, and institutional transformation" (http://www.league.org, September, 8, 2002). During the 1990's, many community colleges made a commitment to become more learning centered by adding learning centered values to their programs and mission statements. To demonstrate its commitment to the learning centered college, the League established the Learning College Project.

\section{Vanguard Learning Colleges}

In January 2000, an international team of community college scholars and practitioners well versed in Learning College concepts selected 12 colleges from 94 applications as Vanguard Learning Colleges. According to the League for Innovation in Community Colleges website, the 12 Vanguard Colleges will "become incubators and catalysts for the Learning College concept for other educational institutions around the world" (http://www.league.org/league/projects, September 8, 2002). The project was funded through 2003 
with the League committing to working with the 12 colleges over a five-year period to achieve the following five project objectives:

Objective 1: Organization Culture. Each of the 12 colleges will cultivate an organizational culture where policies, programs, practices, and personnel support learning as the major priority.

Objective 2: Staff Recruitment and Development. Each of the 12 colleges will create or expand (a) recruitment and hiring programs to ensure that new staff and faculty are learning centered and (b) professional development programs that prepare all staff and faculty to become more effective facilitators of learning.

Objective 3: Technology. Each of the 12 colleges will use information technology primarily to improve and expand student learning.

Objective 4: Learning Outcomes. Each of the 12 colleges will agree on competencies for a core program of the college's choice, on strategies to improve learning outcomes, on assessment processes to measure the acquisition of the learning outcomes, and on means for documenting achievement of outcomes.

Objective 5: Under-prepared Students. Each of the 12 colleges will create or expand learning-centered programs and strategies to ensure the success of under-prepared students. (http://www.league.org/league/projects, September 8, 2002).

The relevancy of the League's five objectives for Vanguard Colleges to this study is no more apparent than those expressed in Objectives 1 and 4 above. With a focus on learning outcomes as stated in objective 4, colleges are expected to agree upon strategies to improve learning outcomes and a means for documenting these outcomes. An 
expected outcome of objective 1 includes an expectation that colleges "create decision-making structures to ensure involvement of all key stakeholders" (Vanguard Goals, League for Innovation in Community College, http://www. league.org, 2002).

\section{Community College Decision-making Models}

According to Gibson et al. (1985), members of an organization need to communicate for many reasons but primarily during decision-making (p. 567). Organizations consist of many people behaving as individuals while simultaneously serving as group members within the defined structure of the organization. Gibson et al. (1985) asserts, "much evidence exists to support the claim that in most instances group decisions are superior to individual decisions" (p. 588). Generally speaking, groups can do a better job than individuals in two important functions in the decision-making process: defining the problem and generating alternative solutions (Williams, 2003, p.206). However, group decision-making can also create "groupthink" where in highly cohesive groups, members feel intense pressure to agree with each other. According to Williams (2003), "groupthink" is most likely to occur when a group is insulated from others with different perspectives. Or, when the group leader begins by expressing strong 
preference for a particular decision. Also, when there is no established procedure for systematically defining problems and exploring alternatives. And finally, when group members have similar backgrounds and experiences. (p.207)

Therefore, the conceptual foundation for this study is shared decision-making, which forms the basis for the theoretical frameworks identified as most relevant to this study namely, the political and collegial models of educational management.

\section{Political Model}

Political models assume decisions regarding policy and procedures emerge through a process of negotiation and bargaining (Bush, 2000, p. 73). Political models view organizations as "political arenas where members engage in political activity in pursuit of their interests" (Bush, 2000, p. 73). Political models tend to focus on group activity rather than as an institution as a whole. The emphasis is on group interaction. Because political models are concerned with interest groups with different goals and values, a political model can lead to fragmentation rather than organizational unity. Thus, political models can lead to conflict. Organizations that use a political model tend to emphasize the concept of power. According to Bush 
(2000), "the outcomes of the complex decision-making process are likely to be determined according to the relative power of the individuals and interest groups involved in the debate" (p. 77). This mobilization of the resources of power to support special interests can have a significant impact on policy outcomes. Despite some limitations, political models have much to offer to an academic organization. As cited in Bush (2000), Baldridge et al (1978) concludes that the political model has much strength and can be a strong contender for interpreting academic governance (p. 90-1). The political model is not a substitute for the collegial model but provides complimentary interpretation to the collegial model.

\section{Collegial Model}

According to Bush (2000), collegial models "include all theories which emphasize that power and decision-making should be shared among some or all members of the organization" (p.52). Collegial models assume policy and procedures are made through a decision-making process of discussion striving for consensus (Bush, 2000, p. 52). Baca (1998) maintains that the concept of collegial governance began in the early years of the twentieth century with great strides made over the next several decades to increase the involvement of faculty in the 
decision-making process. Advocates of the collegial model "believe that participative approaches represent the most appropriate means of managing educational institutions" (Bush, 2000, p.70).

Florida's recognition of the significance of involvement in policy-making is reflected in an April, 1997, report by the Office of Program Policy Analysis and Government Accountability (OPPAGA) indicating that all government agencies "are recognizing the importance of key stakeholder involvement in setting policy direction for the reform" (p. ii). Florida's community college system tends to approach decision-making using the collegial model of organizational management. The collegial model emphasizes that "power and decision-making should be shared among some or all of members of the organization" (Bush, 1995, p.52), which is similar to California's shared governance model as described in AB1725. However, Florida's governance model is by convention not by mandate.

According to Moskus (1999), "A college that empowers employees to try new things and welcomes both successes and failures as examples of learning will create a better climate for decision-making, but only if the learning that is produced is shared" (p. 1). Such participation and collaboration is the foundational premise of the collegial 
theories of educational management, which yielded the principle of shared governance in California as articulated in AB1725 (California Code of Regulations, 1990). In a publication released in December 1989, by the California Community College Trustee Association, shared governance was defined as "shared involvement in the decision-making process in a climate of mutual trust. It means involving those affected by the decision in the decision-making process, from faculty and administrators to classified staff and students" (p. 7).

The literature (CCCT, 1989; Deas, 1998; Giese, 1996; Jensen, (2000); Sims (1998); Trombley, 1997; Vaughan, 2000) suggests that effective shared governance requires a commitment from the entire leadership (board, CEO, administration, faculty, and staff) of a college to the concepts of participation, collaboration, teamwork, and consensus. These concepts also abound in management and organizational literature, such as Covey (1991), Peters (1988) and Wheatley (1994), to name a few.

Because community colleges are complex organizations consisting of many constituency groups primarily represented by appointed leadership, union affiliation or committee representation, they function with some form of group decision-making; therefore, both theoretical 
frameworks, Political and Collegial, are considered pertinent to this study. Furthermore, in a qualitative study conducted by Howell in 1997 to assess the impact of AB1725, Howell determined that while the shared governance model is philosophically positive, a truly collegial model is difficult without accountability (p. 5).

\section{Accountability}

One of the primary factors distinguishing a nonprofit organization from a conventional business organization is that theoretically there are no stockholders (owners). Even though no stockholder owns a public college, there are many stakeholders, internal and external, with varied interest, which are not always congruent. This difference is explained in New Thinking on Higher Education: Creating a Context for Change, "Because they do not have owners, nonprofits do not have the same clarity of accountability as business firms" (Meyerson, 1998, p. 35). The significance of accountability in education is evidenced by the constant focus of the media on this issue. Almost daily another article appears in a local newspaper or on television calling for more accountability within education. In fact, both 2000 Presidential candidates' election campaigns had, as one of their primary focuses, accountability in public schools. The concerns frequently 
voiced were with regard to the $\mathrm{K}-12$ education system, but community colleges could not escape the public and legislative momentum building around accountability.

Clearly, issues regarding educational performance and accountability are constantly receiving a significant amount of national and local attention. The attention on costs and accountability measures has also created a fundamental concern by some about the quality of education. In fact according to Bogue (2000), many of the principles, policies and practices that constitute the heritage of higher education were under examination as we moved into the twenty-first century.

In recent years state and federal governments have implemented policies designed to bring greater public accountability to higher education. More than two-thirds of the states now have some requirement vested in state law that requires assessment, and many states now require colleges and universities to make annual reports on a cluster of performance indicators. Other states have policies in which some portion of appropriations to state colleges is linked to performance measures rather than enrollments. (p. 13)

Unfortunately, one of the main problems associated with accountability is that the concept, despite its frequent use, can mean different things to different people. Compounding the problem is the belief of some accountability advocates that public funds are being 
misused (Honeyman, et al., 1996). According to Meyerson, (1990)

The call for increased accountability is the clear signal of a shift from a belief that faculty and administrators are faithful stewards of our young people's and nation's future, to a belief that we are "pigs at the public trough," who-like many others-must be overseen and regulated if we are to make wise use of public funds. (p. 87)

Use of the term "accountability" in higher education is not new as evidenced by a monograph published in 1972 by Kenneth Mortimer entitled Accountability in Higher Education, "Accountability accentuates results--it aims squarely at what comes out of an educational system rather than what goes into it. It assumes that if no learning takes place, no teaching has taken place" (p. 6). This view affirms the changes that have taken place in education, which has transitioned from the resources and reputational model of quality and performance to the results model of quality and performance (Bogue, 2000, p. 214). Bogue (2000) also notes the vast differences in motives and methods of civic and collegiate accountability interests, which create two cultures, such as improvement versus stewardship, process versus results, or consultation versus evaluation (p. 214).

According to Bogue (2000), in good economic times, there is less inclination to ask accountability questions. 
During the last half of the twentieth century, the nation made extraordinary investments in both student access and program availability. However, by the end of the century, state economic conditions changed, resulting in a greater emphasis on the mission, priorities, and focus of public institutions throughout the nation. The most obvious change was the focus on the aggressive posture of external forces--"boards, coordinating commissions, legislators, accrediting agencies--insisting on a more public engagement of quality and performance issues" (Bogue, 2000, p. 213). In January 2000, participants in the 2000 Community College Futures Assembly were asked to identify the most critical issues facing their institutions. They identified 108 issues, which were then narrowed down to the three most significant. According to the participants, the top three overall issues facing community colleges were identifying sufficient and multiple sources of funding for workforce development, appropriately using outcome measures for accountability and the cost of technology. (Institute of Higher Education, University of Florida, Preliminary Report on the Critical Issues Facing Community Colleges, Dale F. Campbel1, 2000). Nowhere are issues of educational accountability more commonly addressed than with accreditation, student assessment and funding. 


\section{Accreditation}

There are six regional associations that accredit public and private schools, colleges, and universities in the United States. Accreditation is voluntary on the part of an institution. An institution associates itself with an accrediting body, which systematically evaluates member institutions to ensure that each meets a set of standards of quality. Members of the association granting accreditation, determine the accrediting standards. "The chief aim of accrediting associations are to help assure the consumers of higher education-parents, students, and employers-that an institution or program is meeting minimum standards and to stimulate those institutions and programs to improve beyond the minimum standards" (Commission on Colleges SACS Membership Information, SACSCOC.ORG website, September, 2002). Two of the six regional accrediting associations relevant to this study are: the Commission on Colleges of the Southern Association of Colleges and Schools (SACS) and the Western Association of Schools and Colleges (WASC).

SACS is the recognized regional accrediting body for eleven U.S. Southern states (Alabama, Florida, Georgia, Kentucky, Louisiana, Mississippi, North Carolina, South Carolina, Tennessee, Texas and Virginia) and Latin America 
in those institutions of higher education that award associate, baccalaureate, master's or doctoral degrees. (http://www.sacscoc.org website, home page, September, 2002). WASC covers institutions in California and Hawaii, the territories of Guam, American Samoa, Federated States of Micronesia, Republic of Palau, Commonwealth of the Northern Marianas Islands, the Pacific Basin, and East Asia, and areas of the Pacific and East Asia where American/International schools or colleges may apply to it for service. (WASC website's Home Page, http: //www.wascweb.org, September 2002).

Each of the accrediting associations operates similarly. Following is an explanation of the process used by WASC: Three accrediting commissions evaluate different segments of the educational function. For those seeking accreditation for community colleges, the Accrediting Commission for Community and Junior Colleges Western Association of Schools and Colleges (ACCJC) evaluates and accredits public and private institutions offering one or more educational programs of two academic years in length leading to an associate degree. ACCJC operates under five assumptions including one found to be most relevant to this study, which focuses "on outcomes and accomplishments, embracing a model of accreditation which requires 
assessment of resources, processes, and outcomes at the institutional level" (ACCJC website, Standards for Accreditation, September 2002, http://www.accjc.org) .

The impact of the call for accountability is demonstrated by the ACCJC move in June 2002 towards a plan to make significant changes to their accrediting standards, which include the imposition of an approach to measure institutional effectiveness. The change to standard 1: Institutional Mission and Effectiveness requires that the "institution demonstrates strong commitment to a mission that emphasizes achievement of student learning and to communicating the mission internally and externally" (ACCJC website, Draft C Standards of 5/15/02, September, 2002). The change imposes a controversial educational philosophy as faculty see it as a "marked retreat from a commitment to collegial governance" according to an article published in Perspective, February 2002 entitled "Commission urged to reconsider: New accreditation standards would impose corporate approach". The change requires institutions to utilize quantitative and qualitative data and analysis in "an ongoing and systematic cycle of evaluation, integrated planning, implementation, and re-evaluation to verify and improve the effectiveness with which the mission is accomplished (ACCJC website, 
Draft C Standards of 5/15/02, September, 2002). Community College Council President, Marty Hittelman, speaking on behalf of California faculty, wrote the Accrediting Commission "we do not believe that the 'learning objectives' and 'outcomes' approach to education necessarily produces the highest quality educational experience" (Perspective, February 2002, Commission urged to reconsider: New accreditation standards would impose corporate approach, page 3.) In the same article, the Academic Senate for the California Community College system opposed the standard as it "represents a marked shift in the number and type of standards for accreditation of two year colleges, as well as a reinterpretation of ACCJC's role as an accrediting commission." The Academic Senate cautioned against monitoring of outcomes using the Total Quality Management Approach used in the corporate world. The Accrediting Commission decided to move forward with its plan after hearing public testimony. Clearly, the increased focus on accountability at the national, state, and local levels elevated student assessment into the forefront of educational issues.

\section{Assessment}

An emphasis on assessment places an enormous responsibility on administrators, faculty and students to 
improve educational outcomes. According to the National Business Education Association (NBEA) Yearbook, No. 38, published in 2000 entitled Assessment in Business

Education, "performance standards, such as the National Standards for Business Education, have been created to guide learning and assessment of outcomes" (Preface, p.iii, 2000). The public is demanding student assessment; therefore, it is being promoted by legislators and leveraged by accrediting agencies. According to the NBEA, "educational institutions have responded with an array of theories and approaches to assessment, linking assessment results to everything from graduation standards to performance-based funding" (2000, National Business Education Association, pg. 10).

\section{Performance-based funding}

In addition to the issues of quality assurance, the emergence of the assessment movement, and the current applications of TQM (Total Quality Management) in college settings, there is an increased emphasis on accountability with regard to performance and productivity (Bogue, 2000, p.96). The obsession with performance and productivity cannot be easily explained. It is a complex concept with several definitions related to a variety of institutional functions. Many equate productivity with efficiency. As 
far back as July 1978, Goodwin and Young presented a topical paper, which spoke of the threat of government's control and regulation of public education. In fact, Goodwin and Young (1978) noted how "state legislators are becoming unwilling to increase funding for community colleges, in response to public pressure to control tax levies" (p. 2). Goodwin and Young also predicted that the survival of community colleges was in jeopardy if "they failed to fulfill society's educational needs in a productive way" (p.3)

According to Moak's survey (1999), it was revealed that the 15 member states of the Southern Regional Education Board (SREB) collect detailed cost data with nine of them, one of which is Florida, using the data for productivity or performance measures. Another member state, South Carolina, is

The only state that professes to base 100 percent of its allocation of the state higher education appropriation on performance measures or performance funding. To determine an institution's performance, the South Carolina legislature mandated a system of 37 performance measures of criteria. (Moak, 1999, p.19)

In an unpublished doctorate dissertation addressing South Carolina's legislative Act 359, which established performance-based funding in that state, China (1998) found that accountability, genuine interest in improving public 
higher education, control, duplication, dissatisfaction with the previous funding formula, and a lack of initial input by higher education leaders resulted in the development of the funding plan, which led to the south Carolina legislation. Texas is another state with a long history of working with performance measures. In 1991 it began to link strategic planning in education with performance-based budgeting because "strategic plans produce goals, objectives, strategies, and [outcome] measures" (Performance-Based Program Budgeting in Context: History and Comparison, 1997, p.40). According to Florida's Performance-Based Program Budgeting Report (1997), 44 of the 50 states collect information from budget documents to support the state budget or appropriations process.

Delaware uses cost data from the SREB Data Exchange to support the budget process, while Florida uses not only the SREB Data Exchange but also data collected through a biennial cost study. Hawaii, Utah, and Wisconsin utilize data from special or annual/biennial cost studies, and West Virginia uses the SREB Data Exchange as well as strategic planning documents. These differences reflect variations in the states' political climates and decision-making processes. (p. 14)

Both California and Florida have attempted to deal with the issues of performance-based funding and performance outcomes by enacting initiatives to increase 
funding to community colleges through supplemental funding tied to specific performance outcomes.

\section{California's Partnership for Excellence (PFE)}

Partnership for Excellence budget language can be

found in SB1565, SEC. 35, and Section 84754 of the

Education Code with the following key principles driving

this program:

The Partnership for Excellence is a mutual commitment by the state of California and the California Community College system to significantly expand the contribution of the community colleges to the social and economic success of California. It is structured in phases, with substantial financial investment by the state in exchange for a credible commitment from the system to specific student and performance outcomes.

The state shall commit first to fully funding enrollment expansion both to meet population growth and to expand the college participation rate, and to protecting the colleges against inflationary erosion through annual cost-of-living adjustments. The state shall then commit to annually investing $\$ 100$ million as an infusion into base apportionment funding. (California Community Colleges Chancellor's Concept Paper, 1999)

The PEE program represented California's attempt to tie community college funding to accountability goals and measures. PFE was developed based on system-wide goals consisting of improvements in the areas of transfers, degrees and certificates, successful course completion, workforce development, and basic skills improvement (SB1564, SEC. 35, Section 84754, 1998) with other goals 
under consideration for inclusion. The goals were set for the system as a whole but dependent upon the individual actions of each district.

As stated in PEE, "The Chancellor's Office will facilitate the sharing of 'best practices,' but the success of the Partnership depends upon the wisdom, experience, professionalism and commitment of the staff and governing boards of each district" (Chancellor's website FAQ's (Erequently Asked Questions), 1999). Annually, the Chancellor's office will collect and compile the data from the 72 districts and analyze the combined efforts against the five system goals reporting the results to the BOG, legislators, districts, and the various constituency representatives. If reasonable progress is made toward the system goals, PFE would continue to be funded. However, if the state fulfills its investment commitment but the system makes little or no progress towards attainment of the goals, the legislation authorized the BOG to take further action to assure system accountability.

At the inception of PFE, the Chancellor's office did not publish a list of acceptable uses of PFE funds. It was each district's responsibility to target its use of $\mathrm{PFE}$ funds toward the specific system-wide goals developed according to local situations and needs. As stated by the 
Chancellor's office, "Districts are encouraged to use a majority of these funds for new activities or enhancement of existing activities related to the goals, but this is a decision which would be made locally" (Chancellor's Office

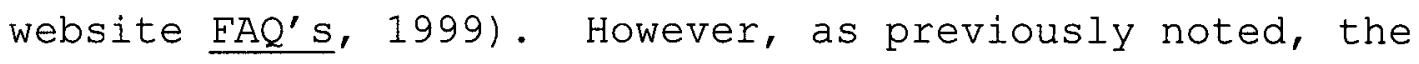
continuation of $\mathrm{PFE}$ funds was contingent upon the good faith effort of each district to meet the intent of the PFE program.

The CCC system is primarily funded based upon a program-based funding which is a formula that considers the number of ETES (full-time equivalent students), credit student headcount, square footage of owned or leased space, and a percentage of administrative overhead in its calculation (Little Hoover Commission, 2000, p. 60). The funding formulas allow for annual adjustments based on adult population and workload growth and inflation. Program-based funding, also legislated in AB1725, drives revenue and is based upon the number of students served and districts receiving categorical funding for specific programs, such as PFE. The BOG determines the distribution of funds to the colleges but it does not dictate how the funds are to be spent. During the first year (1998-99) of the PFE program, the BOG allocated $\$ 100$ million. This amount was increased 
to \$145 million for the 1999-2000 budget and the 2000-01 budget proposed that this be further increased to $\$ 155$ million. If $\mathrm{PFE}$ continued according to its original agreement, the annual augmentation, over the next seven years, would grow to $\$ 700$ million over the base 1997-98's budget for a total of $\$ 2.8$ billion (Little Hoover Report, 2000$, p. 62$)$.

At the end of the first three years, and each year thereafter, the BOG had the authority to implement a contingent funding allocation method if it determined such a change is necessary to improve system performance or to reward individual districts which have significantly improved or sustained goal progress. The precise form for the contingent funding method was not prescribed in $\mathrm{PFE}$ except that any such method must "link allocation of funds in individual districts to the achievement of and progress toward Partnership for Excellence goals by those districts" (SB1564, SEC. 35, Section 84754, 1998).

While there were few or no limitations on how PFE funds could be spent, legislative and budget language clearly suggested that PEE funds should be closely tied to the specific desired outcomes. Individual college progress would not be differentiated for analysis of district goal progress but measured on a system-wide basis. According to 
early reports of $\mathrm{PFE}-\mathrm{related}$ funding activities, a majority of colleges hired additional faculty and staff. However, given that PFE was designed to sunset in 2005-06, some administrators were concerned with how continued employment contracts would be funded (Little Hoover Commission, 2000, p. 63).

In its final report published in March 2000, the Little Hoover Commission, an independent state oversight agency, voiced concerns for the future with respect to $\mathrm{PFE}$ :

Potentially, the colleges are being set up for controversy. The state is investing hundreds of millions of dollars with high expectations that performance will be improved. But the dollars are not directly tied to performance and individual colleges are not being held accountable for how they are spending the money. Seven years and $\$ 2.8$ billion from now, the colleges may well be embroiled in controversy-debating funding formulas and governance structures, and distracted from their assignments of making Californians lifelong learners. (p. 63)

Upon completion of the study, the Commission proposed four recommendations to the Governor and the Legislature, the final two of which are particularly relevant to this study:

Recommendation 3: The Governor and the Legislature should require the Board of Governors to develop a funding system that encourages universal access, teaching excellence and student success. Specifically the Board of Governors should:

- Revise the community college funding mechanism.

a Create incentives for the colleges to improve their services. 
- Establish compacts to fill unmet needs.

- Establish incentives for students to complete a program of study.

- Evaluate and refine incentives.

Recommendation 4: The Governor and the Legislature should reform the community college structure to increase the accountability and efficacy of college leaders. Specifically:

a Strengthen the state Board of Governors, possibly by revising the make-up of the Board of Governors and improving scrutiny of potential appointees.

- Align the Chancellor's Office with its various levels of responsibility.

- Create a California Community College office of Accountability.

- Require all local boards to annually publish and disseminate information on their goals and results.

The original five PEE goals were adopted in 1999

following extensive consultation with internal

constituencies and external interests. However, in late 1999, several agencies expressed concerns about the level of performance contained in the PFE goals. In fact, "since the creation of the Partnership, California elected a new Governor who has made education accountability and performance outcomes assessment major themes of his administration" (Nussbaum and Cabaldon, 1999, p.1). The change in state leadership along with the concerns expressed by the Commission resulted in changes to PFE's original language. In January 2000, the Governor's Budget approved Partnership funding to districts only after the goals had been revised to be "sufficiently rigorous," as 
determined through concurrence of the various agencies expressing concern. It was also indicated that further augmentation to Partnership funding would be contingent on such a revision of the goals. The Chancellor's Office immediately held a series of meetings to satisfy the Governor's request. The revisions required sub-goals that consisted of increased levels of success in the transfer goal, degrees and certificates granted, and workforce development. These changes were presented to the Consultation Council, which concurred with the changes at a meeting on June 15, 2000. (BOG, Revised Goals for the Partnership for Excellence Program, July 2000).

The Chancellor's office released in April 2002 the fourth in a series of reports that presented baseline data specific to the system-wide PFE performance goals at system-wide, district- and college-level. These reports are in accordance with Education Code Section 84754 which requires the

Chancellor's office to report to the Legislature, Governor, the California Post-Secondary Education Commission (CPEC), and other interested parties by April 15 of each year. The annual reports shall include data for each district and college with respect to levels of achievement and relative progress towards the goals... (System Performance on Partnership for Excellence Goals, 1998-99, 1999-00 and 2000-01, April 2002, p. 4). 
In March 2001 and again in March 2002, based on the system's progress in meeting Partnership goals, the Governor determined that it was not necessary to trigger contingent funding. According to the system Performance on Partnership for Excellence Goals, 1998-99, 1999-00 and 2000-01 reported in April, 2002 "the system achieved 101.3\% or $106.0 \%$ (depending upon the method of assessment) of its aggregate interim targets for 2000-01" (2002, p.4). Therefore, it was concluded based on performance, the System is making satisfactory progress towards its 2005-06 goals. Unfortunately, due to limited state resources, PFE has not been funded in the Governor's 2001-02 budget. However, a critical issue facing the CCCS is how to balance open access with PEE performance objectives? How will accountability measures be implemented without an adequate means of tracking outcomes such as students leaving for jobs? Can there be full accountability without openly acknowledging this function of community colleges?

\section{Florida's Performance-based Budgeting ( $\left.\mathrm{PB}^{2}\right)$}

During the 1980s, Florida legislators began to focus on an accountability movement throughout the state. In 1994, the Florida legislature enacted the Government Performance and Accountability Act, which established performance-based program budgeting $\left(\mathrm{PB}^{2}\right)$ for all government 
programs to be phased in over a seven-year period. As with most other states, Florida had increasing demand for services in sectors such as corrections, transportation, health, and welfare. Education was the single largest budget item in the state. However, because of constitutional constraints on the $\mathrm{K}-12$ system, higher education became a target for cost control through performance measures. The public did not believe the results met or exceeded the increasing costs associated with higher education. As stated in a presentation by Yancy, the Bureau Chief of the Florida Division of Community Colleges on November 17, 1998

There was a perception that public colleges and universities were admitting too many unqualified students simply to garner funds from FTE driven funding models. Institutions were accused of graduating too few of the students enrolled, allowed those who did graduate to take longer than necessary to earn their degrees, and allowed too many to graduate without the knowledge and skills to meet the demands of the marketplace. (p.4)

Community Colleges were selected as the first educational delivery system to adopt Performance-Based Budgeting initiatives in Florida. FLCCS began to operate under the $\mathrm{PB}^{2}$ performance-based program budgeting model in the 1996-97 budget. In its 1998-99 $\mathrm{PB}^{2}$ Status Report, Florida's experience showed that focusing on performance improved accountability for state programs, led to better 
public services, and produced cost savings. However, the report also indicated that government agencies needed to develop more comprehensive performance measurement systems, improve data quality, and develop more reasonable standards.

Furthermore, the report (1997) noted that the desire to reform government accountability and the budgeting processes was not something new. This report (1997) also contended that a long-perceived weakness in government was the belief that public entities focused more on bureaucratic processes than on results. Minnesota, North Carolina, Iowa, and Texas and to some extent the federal government all use program performance information for resource allocation decisions in education, but Florida's performance-based budgeting initiative is considered among the most ambitious (Performance-Based Program Budgeting in Context: History and Comparison, 1997, p.ii). The Elorida legislatures chose performance-based budgeting because this method considers how well funds are being used to achieve desired goals.

The Performance-Based Program Budgeting (1997) report also noted that all federal and state agencies that have implemented performance-based budgeting, recognize the importance of key stakeholder involvement in setting policy 
direction and the importance of proper collection, management, and analysis of performance data. According to the report (1997), Florida's $\mathrm{PB}^{2}$ initiative provided greater management flexibility to the state agencies in exchange for accountability.

Agencies should have incentives to deliver services and products efficiently and effectively. Their performance in achieving desired outcomes should be measured against clearly defined missions, goals, and objectives. Finally, information on performance and public benefits of government services should be provided to the state's citizens. (p.2)

The report also revealed that Florida's 28 Community College system's performance-based budgeting approach differed from other approaches used in Florida by directly linking community college performance to a portion of state funding. Community colleges are awarded points based on a number of output and outcome indicators and then incentive funds are apportioned based on the number of points earned (Review of the Community College System's Performance-Based Program Budgeting Measures and Incentive Fund, 1998).

In addition, the Florida Performance-Based Program Budgeting report indicated that only 44 of the 50 states collect information from budget documents to support the state budget or appropriations process.

Delaware uses cost data from the SREB Data Exchange to support the budget process, while Florida uses not only the SREB Data Exchange but also data 
collected through a biennial cost study. Hawaii, Utah, and Wisconsin utilize data from special or annual/biennial cost studies, and West Virginia uses the SREB Data Exchange as well as strategic planning documents. These differences reflect variations in the states' political climates and decision-making processes (Survey, p. 14).

Florida's performance standards were developed at both the institutional and system level. A significant indicator of how the FLCCS accountability system links performance standards and the budget are best illustrated by the fact that a separate source of funds is distributed based upon the points earned. The legislature established the performance measures and the Florida Board of Education set the performance standards. The focus of the standards is on student achievement and learning in order to provide Floridians with information on how well public funds are being used to educate students throughout the K-20 system. The Governor's 2001-02 budget provided nearly a 5\% increase in state funds in the college operating budgets, which resulted in a $\$ 10$ million increase in Performance-based Budget Program allocation to FLCCS (Armstrong memorandum to Community College Presidents, January 17, 2001).

\section{Student Outcomes}

According to a report in Community College Week, June 24, 2002, "approximately 5.6 million students are now enrolled in U.S. two-year colleges, with the vast majority 
(97 percent) attending community colleges and other publicly funded institutions" (p. 6). In addition, the report noted that many two-year colleges were increasing certificate offerings in response to business and industry needs. A key performance goal for both California's and Florida's performance funding programs dealt with increases in degree and certificate awarding and workforce development. Of the top 100 institutions awarding Associate's Degrees (all disciplines), 16 are community colleges in Florida and 23 are in California. The two state community college systems combined represent 39 of the top 100 nationwide community colleges. Florida holds the distinction of the top three two-year institutions in the U.S. conferring Associate degrees. Associate degree conferrals as with the national population have significantly increased in the southeast, Southwest and West. Based on preliminary numbers reported for the 200001 academic year, there has been a nationwide increase of $13 \%$ in associate degree production between academic years 1992-93 and 2000-01 (Community College Week, June 24, 2002, p. 8$)$.

However, a notable challenge facing public colleges and universities is the fact that proprietary (private, for-profit) institutions more than doubled their degree 
output. As stated in the Community college Week article Onward and Upward: Trends and Analysis in Associate' Degree Conferrals, "if these rates of growth continue unabated, proprietary institutions will surpass the public sector in associate's degrees conferred in 20 years" (June 24, 2002, p. 8). During the year 2000-01, approximately 560,000 associate's degrees were awarded by community colleges, which means that two-year colleges confer one associate's degree for every 10 enrolled students (The Top 100 Associate's Degree Producers, Community College Week, June 24,2002, p. 6). Clearly, based on this report, Florida and California legislators are attempting to respond to increased productivity in their respective community college systems; however, the responsibility for achieving performance standards rests primarily at the local level with the leadership.

\section{Community College Leadership}

\section{Leaders and accountability}

Because the concept of productivity includes so many variables, one would expect equally diversified methods for achieving and measuring productivity. Goodwin and Young (1978) developed "survival tactics" for managers and leaders faced with demonstrating accountability. Although not all were directly related to productivity, they 
believed that developing a clearly focused mission, establishing generally democratic governance structures, permitting many people to exercise leadership while engaging in effective decision making and being cost effective would all further that goal (p.5).

Goodwin and Young (1978) viewed education, work, and leisure as a triangular relationship providing options available to individuals at many times in their lives; therefore, the highest level of productivity would be the ability of community colleges to devise new approaches to meet the changing needs (p. 7). Additionally, they believed community college leadership needed to continue to work with the community to communicate the benefits and value of a higher education in order to garner support for state assistance through continued funding from state appropriations rather than merely through increased tuitions. In A Struggle to Survive: Funding Higher Education in the Next Century, Honeyman, Wattenbarger and Westbrook (1996) urged community college leadership to take charge of the public debate on higher education and shift the emphasis from the continuing justification for higher education and fights over scarce resources to the broader and more important issues of "what students need to know, how they should learn it, and how colleges will continue to 
adapt and be responsive to their respective communities' needs" (p. 184).

\section{Leaders and student performance}

Designing college systems that encompass well-crafted quality assurance principles is a worthy endeavor: however, Bogue (2000) warns academia against an overemphasis on quality and performance.

The concepts of performance evidence, continuous improvements, decision utility, external referenced accountability, and mission distinction are important governing ideals of quality. They nurture quality in our colleges and universities, however, must go beyond these conceptual and technical responsibilities. We need to do more than put on the "clothing" and outward appearance of quality via our systems and structures. We need to touch the soul of our colleges and universities. What unites the systemic and the personal dimensions of quality? The uniting element is a habit of mind and heart that creates a community of caring. (p.106)

Bogue (2000) illustrates the concept of creating a community of caring by referencing Alverno College in Wisconsin and Truman State University in Missouri as two institutions which have a substantive and substantial reputation for quality because they have built a link between assessment and learning but, more significantly, because they have created institutions where the "link between personal and systemic servants of quality are almost indistinguishable" (p.106). According to Bogue 
(2000) such institutions create an environment where policy and action nurture both students and standards.

Similarly, in a report released in March 1998 by The New Millennium Project on Higher Education Costs, Pricing and Productivity

Unless new approaches to higher education finance and administration are devised that allow costs to be managed, student access to be protected, and quality to be maintained, the capacity for America's colleges to meet the nation's social and economic needs in the future will be jeopardized. (1998, p. 3)

The Ford Foundation and The Education Resources Institute sponsored the Millennium Project program. It is a multi-year effort to improve the understanding of and facilitate reform of the complex system for financing higher education. The project's initial report Reaping the Benefits: Defining the Public and Private Value of Going to College concluded that higher education must fundamentally restructure itself to meet the needs of society. However, "Presidents, trustees, faculty, student leaders, and statewide higher education officials need to develop new tools for managing transformation that protect the basic social and economic mission of collegiate higher education while simultaneously adapting to major change" (1998, March, p.3). 
However, how does an educational institution or its leaders measure performance and productivity? According to Moak (1999), there is no concrete information available on the relationship between dollars of input and quality of output in higher education (p.21). Conversely, any business accountability model is based on this fundamental relationship between inputs and outputs. One possible definition of accountability in a business organization as defined in Wendell's Corporate Controllers Manual (1981)

Requires that the responsible individual or unit provides some evidence that the assigned tasks were accomplished and submit a report comparing the outcome to the plan [projected costs]. This concept of control through accountability focuses on the major reason for management's introduction of control. In general, through anticipation, measurement, and adjustment, controls help organizations realize planned objectives. (Chapter 17, p.3)

More than twenty years ago, Goodwin and Young (1978) developed "survival tactics" for academic managers and leaders. Although not all of the tactics were directly related to productivity, they determined and reported that developing a clearly focused mission, establishing generally democratic governance structures, permitting many people to exercise leadership while engaging in effective decision-making, and being cost effective would all further performance-based funding goals (Goodwin \& Young, 1978, p. 5). 


\section{Leaders and the challenges ahead}

Ideally, leaders should be technically competent, able to measure statistical data, but also able to balance the human aspect within an institution. Leaders must also build an understanding that the human aspect is a) valuable, b) necessary, c) not necessarily quantifiable, and d) real i.e., human. As the public calls for more accountability, the nation's community colleges are faced with increased student diversity and the need to strategically plan which programs to offer and where to offer them in their community to meet student needs. In an interview with George Baker appearing in Community College Week, February 18, 2002, Dr. George Baker stated that "There is an ideal way of organizing and running each institution but if we are to resolve the difficulties in finding that ideal, we have got to have better leadership and better management systems to operate those campuses" (p.7). Community College leaders have many challenges facing them in the $21^{\text {st }}$ century. While leaders need to be decisive in facilitating planning and decision-making processes, a balance must exist between involving others in decision-making and moving forward. Successful leaders in corporate America and in the Academy know the importance of collaboratively developing a vision and plan that involves the college's 
constituencies who have a stake in the outcomes. Community College leaders face the challenges of leading their institutions in an "age of information technology, globalization, belt-tightening, and accountability" according to The Leading Edge: Competencies for Community College Leadership in the New Millennium. Therefore, current and future community college leaders must foster governance structures that ensure innovation and creativity (League for Innovation, 2001, p. 49).

\section{Summary}

The literature reviewed indicates a need for further study on several issues facing the California and Florida community college systems. Probably the most significant is related to the future of accountability. The primary concern is that the literature includes a preponderance of interest on the part of legislators and the public in accountability measures through increased productivity and efficiency. Will legislators call for further accountability and performance funding measures? If so, is the decision-making process used in each state a factor in developing further accountability measures? Because participatory decision-making, known as shared governance in California, is a philosophical belief as well as a process, it is difficult to narrowly focus on the topic. 
Shared governance, in the collegial sense, is as old as the academy and has reached a heightened significance in the California Community College system primarily due to legislation, but this leads to a philosophical question, which was raised in one of the articles reviewed: Is it possible to mandate collegiality? This leads to another question: Can there be true accountability if individual or constituency interests are placed above that of the whole? Because Political models characterize decision-making as a bargaining process, "power accrues to dominant coalitions rather than being the preserve of formal leaders" (Bush, 1995, p.73). Collegial model advocates believe participative approaches represent the most effective means of managing an educational institution. However, detractors see collegiality as underestimating the official authority of the leader and it assumes that consensus can always be reached, which may not always be the case.

The literature suggests that agreement must be reached as to what the various constituencies--public, legislators, administrators, and faculty--mean when discussing accountability, e.g., does accountability refer only to student success measured by transfer rates, degrees and job placement? Is this a shared definition? Are these outcomes the only measurement that can be used to evaluate 
educational effectiveness? If not, what are the alternatives?

Finally through the review of the literature, it became apparent that funding and costs are critical factors when discussing accountability and performance objectives. All of the literature reviewed suggests that funding has not been adequately handled and, in fact, contributes to some of the inconsistencies and challenges facing each state's community college systems. Both systems appear to be under-funded and face future funding shortfalls with increased demand for productivity.

An example of this funding shortfall is demonstrated by the fact that while the state of California mandated shared governance and other key factors in AB1725, it is difficult to assess the effectiveness of the bill because it was never funded by the state even though it has been more than 10 years since the legislation was passed. Similarly, while PEE is an attempt at developing an accountability program in the CCC system, scheduled to sunset in 2005, additional state resources are not expected. How can performance-based incentives that have a sunset date hope to instill a cultural change within an organization in such a short time period to ensure that improvement will be ongoing? Can a program (PEE) with the 
stated limitations and with such large system-wide goals and expectations have a significant impact on the California Community College System?

On the other hand, Florida's performance-based budgeting appears to be working well for the state; however, in its pursuit of increased accountability, Florida recognized the need to overhaul its entire educational governance system. With the passage of HB2263, the legislators decided to "wipe the slate clean" and build a new governance model that is seamless and studentcentered promoting academic success. The New Florida Board of Education will be established effective January 7, 2003. Florida's new K-20 governance model reinforces the need for accountability for decisions at every level of student learning thereby, making those in education - elected or appointed - subject to judgment regarding their commitment to educational excellence.

In conclusion, the literature reviewed attempts to highlight some of the key issues necessary for consideration if there is to be true accountability for student performance outcomes in a community college setting. Community college institutions have inherited traditions of collegiality or as is the case with California, participatory decision-making was mandated by 
legislation. However, it is important to recognize that while AB1725 legislated, among other things, shared or participatory decision-making at the system level, shared decision-making existed at the local level in varying degrees through the collegial process prior to the passage of AB1725. Finally, the public has increasingly called for assurances that funds are being properly used and yielding the outcomes desired with regard to student performance. Shared decision-making and accountability are complex issues and while extensive literature exists on each of the issues, none could be found which linked the relationship between a decision-making process used to govern and attempts at instituting accountability issues tied to performance outcomes.

This study has been designed to explore these issues and the relationships as they relate to the California and Florida Community College Systems. 


\section{CHAPTER 3 :METHODOLOGY}

How one integrates data to support the analysis and interpretation is not as important as achieving some balance between the two. No case study should be all empirical data or all theoretical analysis. It is the mixture that conveys to the reader the researcher's interpretation of the case and the basis for that interpretation.

Case Study Research in Education:

A Qualitative Approach, Sharan B. Merriam, Chapter 11, p. 203

\section{Introduction}

This chapter describes the methodology used to collect and analyze the data gathered in this study. The purpose of the study is to examine the impact of governance, whether shared by legislative mandate or by convention, on attempts to institute accountability measures in two states with comprehensive community college systems. A further objective of this study is to compare both systems' models of governance to illustrate how the decision-making process used impacts a performance-based funding program in each state.

The study uses a qualitative, case study approach, concentrating on one community college in each of the two states. A variety of data sources, including interviewing, 
document collection and analysis, and historical review were used to triangulate the data. Triangulation was primarily achieved through data collection and analysis at the state (system) and local (college) level.

\section{Conceptual Framework}

The underlying conceptual framework, which forms the basis for this study is presented in the following diagram.

Figure 1: The Conceptual Framework

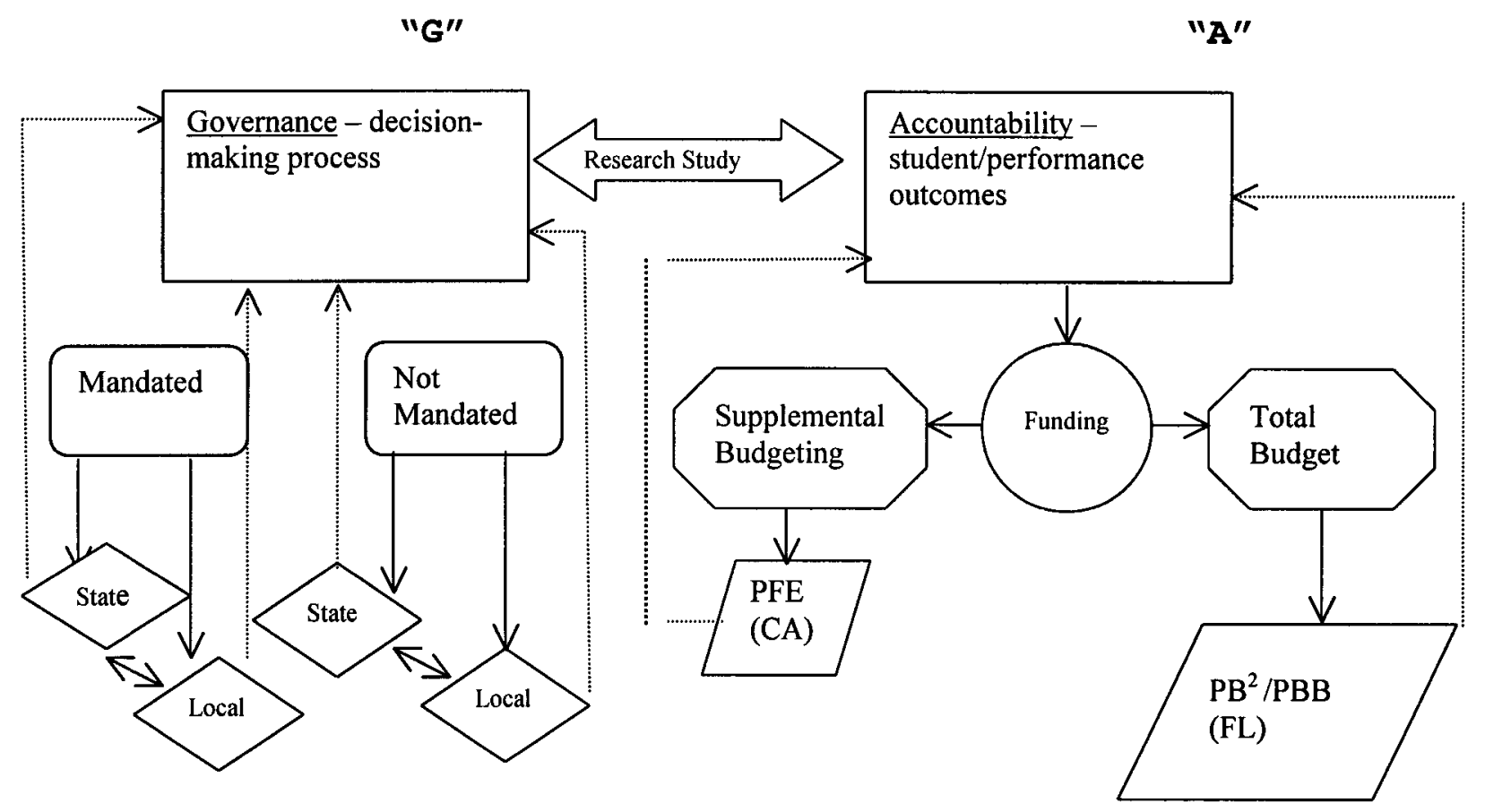

Eigure Captions:

"G" represents the political methods of influencing governing decision e.g., lobbying.

"G" represents the legislative process in governance, mandated or not mandated.

" $A$ " represents the reporting relationship between funding and accountability.

- " $A$ " represents the legislative process of budgeting and funding. 


\section{Research Questions}

The research questions addressed in the study are the following:

1. What is the governance or decision-making process used for community colleges in each state as described by key stakeholders?

2. What effect, if any, did the governance process have on the development of the accountability measures and performance-based funding initiatives currently in existence ( $\mathrm{PFE}$ in California and $\mathrm{PB}^{2}$ in Florida) as perceived by key stakeholders?

3. What differences, if any, exist within each state's governance process to indicate any possible impact on how each state is addressing accountability and performance-based funding?

4. How has the states' governance process impeded or advanced the formation and implementation of the performance-based funding process (PEE in California and $\mathrm{PB}^{2}$ in Florida) as perceived by key stakeholders?

Additionally, the following sub-research question was

inherent in each of the above questions: How, if at all, do these perceptions differ at the state (system) level from the local (college) level?

\section{Design Rationale}

A qualitative case study approach was selected for this study for a number of reasons. First, the research questions are exploratory, descriptive and explanatory in nature. Exploratory studies seek to answer questions linking answers by related patterns, themes and categories. Descriptive studies describe phenomena being studied 
according to common behaviors, events, attitudes, structures and processes. Explanatory studies ask how events and policies interact. Merriam acknowledges, "While some case studies are purely descriptive, many more are a combination of description and interpretation or description and evaluation" (Case Study Research in Education: A Qualitative Approach, 1998, p.29).

This study was designed as an inquiry of two community college systems at the state (system) level and the local (college) level in an attempt to evoke a broad understanding of the phenomena under study. It is a case study analysis utilizing a variety of qualitative research methods. According to Patton (1990), a "qualitative inquiry strategy emphasizes and builds on several interconnected themes" (p. 39). Three themes as identified by Patton (1990) used in this study are naturalistic inquiry, inductive analysis and qualitative data (p.40). Naturalistic inquiry allows for "openness to whatever emerges" (Patton, 1990, p. 40) as this study attempts to present a narrative of the decision-making process found in both community college systems. Inductive analysis is based on discovery rather than theory testing as the researcher comes to understand patterns that exist in the case being studied (Patton, 1990, p.44). Finally, because qualitative 
data captures personal perspectives and experiences of the participants through in-depth inquiry, Patton (1990) advocates a paradigm of choices where the methodological quality of a study is judged by whether the design decisions are appropriate given "the purpose of the study, the questions being investigated and the resources available" (p. 39). Patton (1990) also argues that a qualitative case study permits the analysis of selected issues in depth and detail. Merriam (1988) concurs, "A case is selected because it is an example of some phenomenon of interest" and there is a desire to understand the phenomenon in a "holistic manner"(p.153). And the phenomenon of interest in this study is the relationship between shared decision-making and attempts at accountability measures tied to performance outcomes. Finally, Patton (1990) stresses there are no rules of thumb on how a researcher should focus a study; rather, the researcher must determine the breadth versus depth of a study based on the purpose of the study and the time and resources available.

\section{Sampling and Selection of Sites}

Purposeful sampling was chosen as the method for selecting the two state systems to be analyzed in this study. Purposeful sampling is a process of selecting cases 
for study that illuminates the questions under study (Patton, 1990, p.169). According to Patton (1990), qualitative inquiry typically focuses on selected or purposefully chosen samples because "the logic and power of purposeful sampling lies in selecting information-rich cases for study in depth" (p.169). Merriam (1988) concurs in that "purposeful sampling is based on the assumption that one wants to discover, understand, gain insight; therefore one needs to select a sample from which one can learn the most" (p. 48). "The researchers and intended users involved in the study think through what cases they could learn the most from and those are the cases that are selected for study" (Patton, 1990, p. 170). Furthermore, Patton (1990) suggests combining methods identified as a "combination or mixed purposeful sampling" approach because research often serves "multiple purposes and more than one qualitative sampling strategy may be necessary"(p. 181). In keeping with Patton's (1990) scheme of sampling strategies, two purposeful sampling methods were used (1) the intensity method and, (2) the "snowball" or "chain sampling" method (Patton, 1990, p. 169-183).

The intensity sampling method was used to select the states and colleges to be studied with chain sampling used to select the system and college participants (Patton, 
1990, p.169-183). An intensity sample consists of

"information-rich cases that manifest the phenomenon of interest intensely (but not extremely)" (Patton, 1990, p. 171). Several factors contributed to the purposeful selection of California and Elorida, primarily, California was selected because it appeared to be a case of sufficient intensity to illuminate the nature of success or failure concerning community college governance. As a result of the mandate of $A B 1725$, California is required to use a shared governance decision-making process at the system and college level. Florida, on the other hand, appeared to be in the national forefront in connecting performance measurements with the budget process for funding decisions. Florida's "performance-based budgeting initiative is among the most ambitious in the nation" (OPPAGA, PerformanceBased Program Budgeting in Context: History and Comparison, p. ii) indicating it manifests intensely issues with respect to performance-based funding. Florida's $\mathrm{PB}^{2}$ connects all budget decisions to performance while California's PFE provided for supplemental funding tied to performance in excess of program-based budgets. Therefore, Florida was selected because, compared to other community college systems with legislated performance-based funding, 
it appears to be an information-rich example though not necessarily an unusual case.

The performance-based programs of both states, PFE in California and $\mathrm{PB}^{2}$ in Florida, have similar accountability goals associated with each program regarding student performance outcomes; however, the overarching difference between the two performance-based programs is the governance process used to design, create, and institutionalize both programs. California's PFE was developed through a mandated participatory decision-making process. Florida's $\mathrm{PB}^{2}$ was legislated. A review of the literature was conducted to determine the nature of the variations between California and Florida's decision-making models and to identify the similarities and differences between the two state performance-based funding programs. In addition to the issues of governance and performancebased funding, there are other visible similarities and differences that appear to support selection. The most obvious similarity is that California and Florida are geographically located on opposite sides of the continental United States representing a sweeping view of the nation's community college systems. Both states are coastal states with very similar demographics consisting of a large emigrant and immigrant population with English as a second 
language and significant population growth. Additionally, each state legislated a performance-based funding program within the past six years from inception of this study for its community college system, tied to similar accountability measures primarily related to student success. Finally, both community college systems anticipate tremendous enroliment growth over the next 10 to 20 years (California and Florida website, General Information: Education, 2000).

Conversely, there are several differences between the two states: most notably, California legislated a decisionmaking policy identified as "shared governance" through the passage of AB1725; whereas, Florida has had no such legislation. California and Florida have local governing boards of trustees with ultimate authority for each college; however, the voters from the community elect California's local trustees. Whereas, Florida's local trustees are appointed by the state Governor. Finally, while many other states have legislated and institutionalized performance-based funding models similar to Florida's $\mathrm{PB}^{2}$ which ties budget decisions to attainment of specific accountability goals or objectives, California's program tied less than $10 \%$ of its community college budget to attainment of the specific performance 
objectives (Moak, 1999, p.14). Because of the various nuances associated with governance, accountability and performance-based funding, California and Florida appeared to represent situations that are information-rich with regard to issues of governance and accountability. Because the intensity sampling method requires considerable judgment on the part of the researcher (Patton, 1990, p. 169-183), prior exploratory work was completed to determine variations in the phenomenon of interest resulting in the inclusion of California and Florida in this inquiry. In addition, it is expected that both state systems will increase understanding and knowledge with respect to the impact of governance on state initiatives addressing educational accountability such as, $\mathrm{PFE}$ and $\mathrm{PB}^{2}$.

After the states had been selected, it was determined that a complete description of the phenomenon of interest must include an inquiry at the local level; therefore, two community colleges, one from each state, were selected to be included in the study. The intensity sampling method was also used to choose the two state colleges based upon several factors. Florida's college had recently hired a president while California's college was in the process of hiring a president; however, even though California's 
college was required to do so by state mandate, both colleges used consensus group decision-making in its presidential hiring processes.

Finally, the two colleges were selected in 2000 by the League for Innovation in the Community College as two of 12 colleges to participate in a five-year Vanguard Colleges program. "The twelve Vanguard Learning Colleges will become incubators and catalysts for other educational institutions around the world as they share models and practices to transform community colleges into more learning-centered institutions" (League for Innovation website, Projects Update, 2000). The twelve Vanguard Colleges will participate in a five-year study administered by the League to foster the development of more learning-centered community colleges throughout the United States and Canada (League for Innovation website, 2000). Only 12 colleges throughout the United States and Canada were chosen, further suggesting that the two colleges represent information-rich cases with regard to student performance outcomes as well as intense examples of how shared decision-making might be used in the governing of community colleges. 


\section{Selection of Participants}

The sampling method used for selection of the participants was the snowball or chain sampling method. According to patton (1990), "this is an approach for locating information-rich key informants or critical cases" (p.176). The process begins by asking well-situated people for names of other individuals they believe the researcher should talk to regarding the issues under study. The chain sampling approach was selected because it was anticipated that as with most organizations, a few key names would be mentioned regularly throughout the research process (Patton, 1990, p.176). According to Patton (1990), people recommended as valuable by several informants take on special importance to research inquiry (p.176). The interview process began with California's State Chancellor and Florida's State Executive Director. Participants in such key state positions as legislator, Board of Governor member and faculty leadership were also selected for inclusion in the study. Applying the chain sampling approach, each was asked to identify additional key stakeholders who may not have been previously identified or interviewed. This same sampling approach was used at the local level; however, several participants were initially identified for participation: a local board trustee, the 
college president and faculty senate and/or union president at each institution. Similarly, using the chain sampling method additional respondents were identified and included in the study.

Twenty-nine people were interviewed for the study. At the state (system) level they included:

- California Chancellor and Florida Executive Director

- Legislators (Senate and Assembly)

- Board of Governor members

- Senior system administrators

- FLCCS and FACCC leadership member

- Others involved in development or implementation of $\mathrm{PFE}$ or $\mathrm{PB}^{2}$

At the college (local) level they included:

- Active or Interim College President

- Chair, Board of Trustees

- Senior Administrators

- Faculty leadership (Association and Senate)

- Faculty members familiar with PFE or $\mathrm{PB}^{2}$

Participants were assured of anonymity in their remarks and thus some responses may have been altered to mask identity. However, both Chancellors understood that 
some comments would by nature of their knowledge, be directly attributable to them. Therefore, quotes or attributions will not be identified to any one individual but broadly identified as: governing, executive, administrative or faculty.

The following table represents a list of the types of individuals interviewed and how they will be identified for purposes of this study:

Table 1: Participant Identifiers

\begin{tabular}{|l|l|}
\hline $\begin{array}{l}\text { Participant } \\
\text { identifier }\end{array}$ & \multicolumn{1}{|c|}{ Types of position held } \\
\hline Governing & $\begin{array}{l}\text { Legislators (House Representative, } \\
\text { Assembly and Senate), State Board of } \\
\text { Governors' members, members of the } \\
\text { College's Board of Trustees }\end{array}$ \\
\hline Executive & $\begin{array}{l}\text { System Chancellors and senior staff } \\
\text { members at the system level, College } \\
\text { Presidents and senior administrators at } \\
\text { the college level }\end{array}$ \\
\hline Administrative & $\begin{array}{l}\text { Mid-management members at system and } \\
\text { college level }\end{array}$ \\
\hline Faculty & $\begin{array}{l}\text { Faculty familiar with issues at the system } \\
\text { and/or college level, including those in } \\
\text { current or previous leadership positions }\end{array}$ \\
\hline
\end{tabular}

All participants were asked similar questions as presented in the appropriate interview guide (System or College) (Appendix D\& E). However, responses often raised other issues of relevance, which were addressed in followup questions. The semi-structured interviews lasted 
approximately one hour. Any variations in duration were attributable to the participant's depth of responses and willingness to further explore perceptions. The interviews were conducted in person except in a few instances requiring telephone interviews as a result of logistical and scheduling conflicts. For confidentiality purposes, the California College will hereafter be referred to as West College and the Florida College as East College. During the course of the data collection, all 29 participants referred to various political, demographic, economic, social, representational and funding attributes of each state and college.

\section{Researcher's Role}

The researcher was the research instrument. The research design and methodology were flexible. The proposed design, protocol and timeline were adjusted according to travel availability of the researcher and the schedules of the participants. The study was completed in five phases over a two-year period. Information was initially gathered through document analysis, which included statewide and campus policy statements and documents. Because the study represented an emerging design and was dependent upon the cooperation of initial informants in identifying additional informants, the 
researcher began to search through state documents and various community college organization websites for possible participants.

The researcher attempted to represent the perspectives of each participant in the case study and to accurately present an interpretation of their experiences.

\section{Data Collection}

Interviewing, document collection and analysis, and a historical review of both state systems were the primary data collection methods used in this study. The multiple sources of data complemented each other resulting in triangulation of the data; however, triangulation primarily resulted through data collection at the state and college level (Glesne, 1999; Patton, 1990).

\section{Document Analysis} According to Glesne (1999), "Documents corroborate your observations and interviews and thus make your findings more trustworthy" (p. 58). State and local documents describing the history and impact of each state's past and present legislation regarding governance and accountability were reviewed, analyzed and contrasted to form a historical perspective of each state's system (see Document Review Analyzer (Appendix F). 


\section{Interviews}

In an effort to gain insight into each respondent's perspective, interview questions were open-ended to maintain the conversational aspects of the interview. The conversational interview method allowed the interviews to be personalized to each individual's circumstances because the intent of this study is to illuminate the phenomenon under inquiry. However, the interview guide approach was used to ensure that the data collection systematically covered the aspects related to the purpose of the study and to allow for cross-case analysis. Two interview guides were developed (a) for the state level interviews, and (b) for the college level interviews (Appendix A \& B). Interviews lasted approximately one hour. All were conducted in-person with the exception of three interviews, which were conducted by phone due to scheduling conflicts and logistical considerations. Follow-up questions were designed based on omissions or lack of clarity in each of the original interviews and asked via e-mail or telephone inquiry.

\section{Participant Review}

Participants were asked if they wished to review the transcript. Only two of the participants responded in the affirmative. Complete transcripts were sent to both 
participants along with a stamped self-addressed envelope but neither returned transcripts with any changes.

\section{Data Management}

Materials related to data collection were maintained in separate files. Permission (Appendix $B \& C$ ) had been requested to tape the interviews, which were transcribed by the researcher following each interview session. The transcripts were inductively coded using the research questions as a framework. N5, a qualitative data analysis software program, was used to organize the categories that emerged from the coding. Copies of the tapes, transcripts and coding categories were maintained.

In addition, field notes were maintained throughout the process. Field notes were coded and identified as descriptive observations, direct quotations or researcher insights. The researcher also maintained a reflective journal to identify any assumptions or preconceptions that may have influenced or biased data collection. The journal also served as clarification of the issues as the study progressed.

\section{Data Analysis}

The theoretical frameworks and the work of Rubin and Rubin (1995) referenced in Interviewing: The Art of Hearing Data served as a general guide during initial data 
analysis. According to Rubin and Rubin (1995), "data analysis is the final stage of listening to hear the meaning of what is said" (p. 226). Data analysis is an ongoing process and begins with the interviewing process. Qualitative researchers tend to use inductive analysis of data allowing the critical themes to emerge from the data (Patton, 1990; Stake, 1991). It was anticipated that during the data analysis, themes and concepts from the interviews would give a further explanation of the theoretical or practical importance of the findings discovered.

This search for themes is similar to methods used by Spradley (1979) where the researcher begins with a widearching analysis, such as a domain analysis to identify relationships and terms to organize data according to recurring themes. According to Spradley (1979), doing this kind of analysis allows the researcher to search for "cultural symbols that are included in larger categories (domains) by virtue of some similarity" (p. 94) forming a cluster of related terms. These clusters then become a major coding category with the ideas treated as subcategories, which then are organized into groupings of ideas that are thematically related, a process labeled by Rubin and Rubin (1995) as "axial coding" (p. 247). As 
suggested by Rubin and Rubin (1995), the data was examined as it was heard to identify concepts and themes that described the situation and to determine which areas required further investigation. This process allowed for the redesign of questions to focus on central themes as participant interviewing continued. Upon completion of interviews, a more formal analysis compared the data to discover additional themes and concepts to allow for an accurate and detailed description of the research phenomenon.

Coding of data was done using $N 5$. N5 is the latest version in the leading NUD*IST qualitative data analysis software. The use of the same categories and sub-categories across cases to the extent possible helped facilitate the cross-case analysis. A variety of data sources, including interviewing, document collection and historical review were used to triangulate the data; however, triangulation resulted primarily through data collection at the state and college level (Glesne, 1999; Patton, 1990). According to Glesne (1999), the use of multiple data-collection methods contributes to the trustworthiness of the data (p.31). Two literature reviews, one on accountability and the other on collegiality and shared governance has resulted in a large source of document data. Documents identified included the 
$\mathrm{PEE}$ and $\mathrm{PB}^{2}$ annual reports and legislation related to both programs as well as documents related to collegiality and shared governance. The analysis of these documents (see Appendix F) assisted in confirming interview data while allowing emerging themes to be discovered.

\section{Human Subjects}

Upon confirmation of access to each site and to the initial respondents identified, visits were conducted in accordance with the guidelines established by the University of San Diego's Committee for the Protection of Human Subjects. Informed consent was obtained from all individuals who were interviewed as part of the study. The participants had a right to expect that when they gave the researcher permission to observe and interview them, their confidences would be protected (Glesne, 1999, p. 122). The names of the participants were removed from data collection notes and transcripts, and replaced with a code known only to the researcher. After completion of the study all data will be destroyed.

\section{Summary}

This chapter has addressed the research design and procedures used in the study. A case study approach was used to study the relationship between decision-making and accountability efforts related to student performance 
outcomes in two states with comprehensive community college systems. The researcher was the research instrument and used three data collection methods: structured and openended interviews, document analysis and a historical review of both systems concerning governance, accountability and student performance outcomes. The sampling method, data collection and analysis techniques used to arrive at the findings presented in the following chapter were discussed in this chapter also. Triangulation was achieved through the use of the three qualitative data collections strategies but primarily through the state and college level cross-case analysis. Triangulation and a search for alternative explanations helped ensure the study's trustworthiness. 


\section{CHAPTER 4: FINDINGS}

The turning point for me was an understanding that respecting deeply other people's ideas didn't cost me anything. I didn't give up any authority when I gave other people influence.

East College, executive participant describing a personal quest with regard to leadership style.

\section{Introduction}

This study provides an in-depth look at how internal structures of participatory decision-making (i.e., governance) respond to external requirements for accountability. It represents a case study of two community college systems at the system (state) and college (local) level: California and Florida. The underlying premise for this study is that the governance (i.e., decision-making process), whether mandated or not, employed by a community college system at the state and local level significantly impacts any attempt to achieve educational accountability.

Each state is examined with the findings analyzed in an effort to understand the complexities of the relationship between these internal and external forces. The chapter begins with Tables 2 and 3, which lists attributes compiled from a review of various documents 
provided or referred to by participants during the data collection process. Table 2 lists state/system attributes. Table 3 lists college attributes. An overview of the findings for each state is presented. The overview was compiled as a result of documents reviewed during data collection. This is followed first by each system's interview data presented according to the research questions. And then each college's interview data is presented according to the same research questions. Using information gained from a review of documents and from interviews with 16 system (state) level individuals and 13 college (local) level individuals, for a total of 29 participants, a picture is painted of: 1) what is the governance or decision-making process used for community colleges in each state as described by key stakeholders (Research Question \#1): 2) what effect, if any, this decision-making process had on the development of the accountability measures and performance-based funding initiatives, $\mathrm{PFE}$ or $\mathrm{PB}^{2}$ program (Research Question \#2): 3) what differences, if any, exist between the two state's decision-making process to indicate any possible impact on how each state is addressing accountability and performance-based funding (Research Question \#3): and 4) how the decision-making process has impeded or advanced the 
formation and implementation of the performance-based funding ( $\mathrm{PFE}$ or $\mathrm{PB}^{2}$ ) process in their respective states (Research Question \#4).

Included in the reporting of all findings is the subresearch question inherent in each of the other questions: How, if at all, do these perceptions differ at the state (system) level from the local (college) level?

Table 4 presents the recurring themes emerging from the findings at both the system and college level. A narrative summary of the emerging themes is then presented in an effort to identify unifying issues related to the decision-making process used to govern community colleges in both states and any efforts to address educational accountability.

\section{System Attributes}

The attributes listed on Table 2 and 3 were compiled after reviewing documents referred to by participants during data collection. The Document Analyzer (Appendix F) was used to compile the data.

Table 2: System attributes pertinent to governance, performance funding and accountability by state

\begin{tabular}{|l|l|l|l|}
\hline & \multicolumn{1}{|c|}{ ATTRIBUTE } & $\begin{array}{l}\text { California } \\
\text { Community } \\
\text { College System } \\
\text { (CCCS) }\end{array}$ & $\begin{array}{l}\text { Florida } \\
\text { Community } \\
\text { College System } \\
\text { (FLCCS) }\end{array}$ \\
\hline 1. & $\begin{array}{l}\text { Size of system (number } \\
\text { of colleges/districts) }\end{array}$ & $\begin{array}{l}108 \text { colleges/ } \\
72 \text { districts }\end{array}$ & $\begin{array}{l}28 \text { colleges/ } \\
53 \text { sites }\end{array}$ \\
\hline
\end{tabular}




\begin{tabular}{|c|c|c|c|}
\hline & ATTRIBUTE & $\begin{array}{l}\text { California } \\
\text { Community } \\
\text { College System } \\
\text { (ccCs) }\end{array}$ & $\begin{array}{l}\text { Florida } \\
\text { Community } \\
\text { College System } \\
\text { (FLCCS) }\end{array}$ \\
\hline 2 . & $\begin{array}{l}\text { Size of system } \\
\text { (estimated number of } \\
\text { students served system- } \\
\text { wide) }\end{array}$ & 2.9 million & .8 million \\
\hline 3 . & $\begin{array}{l}\text { Political affiliation } \\
\text { of current Governor }\end{array}$ & $\begin{array}{l}\text { Democrat- } \\
\text { serving } 2^{\text {nd }} \\
\text { term (previous } \\
\text { Governor was } \\
\text { Republican) }\end{array}$ & $\begin{array}{l}\text { Republican- } \\
\text { serving } 2^{\text {nd }} \\
\text { term (previous } \\
\text { Governor was } \\
\text { Democrat) }\end{array}$ \\
\hline 4. & $\begin{array}{ll}\text { Statewide } & \text { Board of } \\
\text { Governors } & \text { (BOG) }\end{array}$ & Appointed & Appointed \\
\hline 5 . & $\begin{array}{l}\text { Statewide faculty } \\
\text { organizations }\end{array}$ & $\begin{array}{l}\text { Statewide } \\
\text { Academic } \\
\text { Senate \& } \\
\text { Eaculty } \\
\text { Association of } \\
\text { California } \\
\text { Community } \\
\text { Colleges } \\
\text { (EACCC) } \\
\text { representing } \\
\text { only faculty } \\
\end{array}$ & $\begin{array}{l}\text { Florida } \\
\text { Association of } \\
\text { Community } \\
\text { Colleges } \\
\text { (EACC) } \\
\text { representing } \\
\text { all community } \\
\text { college } \\
\text { constituencies }\end{array}$ \\
\hline 6. & $\begin{array}{l}\text { Annual Legislative } \\
\text { Session }\end{array}$ & $\begin{array}{l}\text { Year round } \\
\text { with summer } \\
\text { and winter } \\
\text { recess }\end{array}$ & $\begin{array}{l}60 \text { days a year } \\
\text { with year } \\
\text { round } \\
\text { committee work }\end{array}$ \\
\hline 7 . & $\begin{array}{l}\text { State population and } \\
\text { projected growth }\end{array}$ & $\begin{array}{l}34 \text { million } \\
16 \% \text { expected } \\
\text { growth by } 2010\end{array}$ & $\begin{array}{l}16 \text { million } \\
17 \% \text { expected } \\
\text { growth by } 2010\end{array}$ \\
\hline 8 . & $\begin{array}{l}\text { Ethnic breakdown of } \\
\text { students }\end{array}$ & $\begin{array}{ll}52 \% & \text { white } \\
7 \% & \text { black } \\
11 \% & \text { Asian and } \\
& \text { Pacific } \\
& \text { Islander } \\
30 \% & \text { Hispanic } \\
& \text { origin }\end{array}$ & 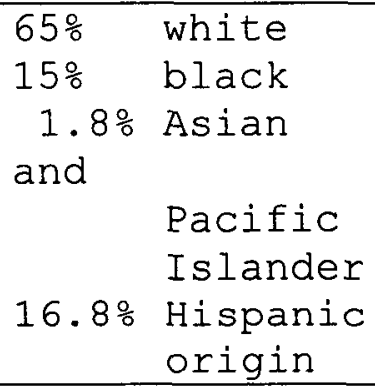 \\
\hline 9. & $\begin{array}{l}\text { Statewide Governance } \\
\text { model for system } \\
\text { decision-making }\end{array}$ & $\begin{array}{l}\text { Mandated } \\
\text { Consultation } \\
\text { Council } \\
\text { process } \\
\text { "shared } \\
\text { governance" }\end{array}$ & $\begin{array}{l}\text { None } \\
\text { (Governance } \\
\text { structural } \\
\text { reorganization } \\
\text { effective } \\
\text { January, 2003) }\end{array}$ \\
\hline
\end{tabular}




\begin{tabular}{|l|l|l|l|}
\hline \multicolumn{1}{|c|}{ ATTRIBUTE } & $\begin{array}{l}\text { California } \\
\text { Community } \\
\text { College System } \\
\text { (CCCs) }\end{array}$ & $\begin{array}{l}\text { Florida } \\
\text { Community } \\
\text { College system } \\
\text { (FLCCS) }\end{array}$ \\
\hline 10. & $\begin{array}{l}\text { System Statewide } \\
\text { Funding }\end{array}$ & $\begin{array}{l}\text { FTE (full-time } \\
\text { equivalent } \\
\text { student) } \\
\text { program-based } \\
\text { and } \\
\text { performance- } \\
\text { based through } \\
\text { equivalent } \\
\text { student) } \\
\text { program-based } \\
\text { and } \\
\text { performance- } \\
\text { based through } \\
\text { PB (PBB) }\end{array}$ \\
\hline 11. & Tuition & $\begin{array}{l}\text { \$11 per unit } \\
\text { plus books and } \\
\text { student fees }\end{array}$ & $\begin{array}{l}\text { \$54 per unit } \\
\text { plus cost of } \\
\text { books }\end{array}$ \\
\hline
\end{tabular}

\section{College Attributes}

Table 3: College attributes

\begin{tabular}{|c|c|c|c|}
\hline & ATTRIBUTE & West College & East College \\
\hline 1. & $\begin{array}{l}\text { Approximate age of } \\
\text { college }\end{array}$ & 57 years & 36 years \\
\hline 2 . & $\begin{array}{l}\text { Number of students } \\
\text { served based on FTE } \\
\text { (full-time equivalent } \\
\text { students) }\end{array}$ & 14,187 & 14,277 \\
\hline 3. & Multi-campus college & Yes & Yes \\
\hline 4 . & Board of Trustees & Elected & $\begin{array}{l}\text { Governor } \\
\text { appointed }\end{array}$ \\
\hline 5 . & $\begin{array}{l}\text { College-wide governance } \\
\text { process for decision- } \\
\text { making }\end{array}$ & $\begin{array}{l}\text { Rely primarily } \\
\text { upon Faculty } \\
\text { Senate for } \\
\text { Academic \& } \\
\text { Professional } \\
\text { matters and } \\
\text { constituency } \\
\text { representation } \\
\text { for all campus } \\
\text { committees }\end{array}$ & $\begin{array}{l}\text { Faculty } \\
\text { representation } \\
\text { on most } \\
\text { committees } \\
\text { particularly, } \\
\text { planning, } \\
\text { budget and } \\
\text { curricula } \\
\text { related. }\end{array}$ \\
\hline 6. & Faculty representation & $\begin{array}{l}\text { Academic } \\
\text { Senate \& a } \\
\text { negotiation } \\
\text { unit }\end{array}$ & $\begin{array}{l}\text { Academic } \\
\text { Senate but no } \\
\text { negotiation } \\
\text { unit }\end{array}$ \\
\hline
\end{tabular}




\section{California Findings Overview}

California consisted of 12 participants at the system and college level. A document identified by two executive participants and given to the researcher during data collection was a monograph written by Chancellor Nussbaum in January 1995 titled Evolving community college shared governance to better serve the public interest. Using the Document Analyzer (Appendix F), the monograph was reviewed and the following findings reported.

When it passed AB1725 in 1988, California's state legislators separated the community college system from $\mathrm{K}-$ 12 education (Chapter 973, Statutes of 1988) further establishing the California Community Colleges as a system. The CCCS is directed at the state level by a system Chancellor reporting directly to a statewide Board of Governors. According to California Education Code, The Chancellor shall be the chief executive officer of the Board of Governors of the California Community Colleges and shall have full administrative authority and responsibility under the policy direction of the Board to carry out its policy directives (EC SS 66700, 70901).

The Governor appoints members to the Board of Governors with appointments made to create staggered terms. The Board of Governors (BOG) sets policy and provides 
guidance for the 72 districts and 108 community colleges. The BOG develops and recommends the proposed annual budget to the legislature and represents the system at the state and national level. Additionally, each of the districts has a locally elected Board of Trustees. The local governing boards are charged with establishing college policies, overseeing the operations of the local colleges and for ensuring that each college responds to its mission in a way that serves the best interests of its students, the district, the CCCS and the state of California.

In addition to establishing CCCS as a system, AB1725 formalized pre-existing shared governance concepts and structures. In March 1988, the BOG adopted a process known as "consultation", which distinguished between policy development and review as directed by AB1725.

The board of governors shall establish and carry out a process for consultation with institutional representatives of community college districts so as to ensure their participation in the development and review of policy proposals. The consultation process shall also afford community college organizations as well as interested individuals and parties an opportunity to review and comment on proposed policy 
before it is adopted by the board of governors. (Education code, Section 70901 (e)) (p.36)

Under the consultation process mandate, institutional representatives were given the primary role regarding policy development. The Consultation Council was created to include representatives for trustees, CEOs, senior and mid-management administrators, the statewide Academic Senate, various faculty associations including bargaining representatives, staff and students. According to Chancellor Nussbaum's (1995) monograph, "there are thirteen statewide organizations that are formally enabled to participate in Consultation by policies of the Board of Governors (p.39). They are identified as:

- ACCCA: The Association of Community College Administrators

- CEOCCC: The Chief Executive officers of the California Community Community Colleges

- CCCT: The California Community College Trustees

- CCE/AFT: The Community College Council of the Federation of Teachers

- CCA: The Community College Association

- FACCC: The Faculty Association of the California Community Colleges

- The Academic Senate for California Community Colleges

- CCCI: The California Community College Independents

- Cal SACC: The California Student Association of the Community Colleges

- CSEA: The California School Employees Association

- CIOCCC: The Chief Instructional Officers of the California Community Colleges

- CCCCSSAA: The California Community Colleges Chief Student Services Administrator's Association 
- ACBO: The Association of Chief Business Officials p. 39-44)

The Consultation Council meets regularly throughout the year developing and recommending policy. In addition to providing for the Consultation Council and a traditional collegial model approach to system governance, AB1725 included specific directives regarding the role of local academic senates. The bill identified eleven areas as academic and professional matters, which required local governing boards, at a minimum to consult collegially with academic senates by relying primarily on the advice and judgment of the academic senate; or reach mutual agreement with the academic senate on these academic and professional matters. AB1725 represented a major reform measure, which profoundly affected the California Community College system formalizing a model of shared governance for decisionmaking at the state and local level. Prior to AB1725 legislation, because California Community Colleges evolved from the K-14 education model, junior colleges had very little in the way of systematic shared governance. Local governing boards had broad power, including the power of taxation. They operated in response to the electorate and a relatively small body of legislative statutes. The extent of involvement of the various campus constituencies in 
governance was at the discretion of the governing board and CEOS.

In addition, three executive participants at the system level cited Proposition 13 (1978) and AB1725 (1988) as having had a direct impact on the issues of accountability and governance in California. According to one executive participant, Proposition 13, a property tax cutting measure, was one of the most significant statutes affecting the CCCS up until that time having had a monumental effect on community college governance. Furthermore, another executive participant stated that as a result of the passage of Proposition 13, local governing boards lost their ability to levy taxes to raise revenues to meet their mission. The perception is that in terms of local governance, Proposition 13 had a disempowering effect. According to three system level executive participants and one college executive participant, the passage of AB1725 ten years later was the response to this disempowerment and had an equally profound effect as it attempted to empower the California Community College system particularly, with regard to governance. According to a system faculty participant, after the passage of Proposition 13, the Board of Governors as well as most trustee and administrative groups had argued for a 
traditional higher education collegial governance approach. However, the Academic Senate and other faculty groups argued that a traditional collegial approach was not enough. According to this faculty participant, there was much debate and controversy resulting in the final language of AB1725 providing for the traditional collegial approach but also further defining the role of academic senates at the system and college level through the eleven specific directives identified as academic and professional matters.

\section{Florida Findings Overview}

There were 17 participants in Florida. According to all, Florida has been grappling for years with issues of accountability and performance tied to student outcomes. All 11 system and some college participants believe issues of accountability and funding were the catalyst for Governor Bush and Florida Legislators calling for an overhaul of the Florida education system. An executive participant at the system level recommended that the researcher review House Bill 2263 Florida's Education Governance Reorganization Act passed in 2000. A review of HB2263 using the Document Review Analyzer form (Appendix F) indicated that a new Board of Education would be created to oversee kindergarten through graduate education. A 
transition task force was formed to help ensure a smooth transition between the previous and new governance model. The same executive participant recommended a review of Senate Bill 1162 (SB1162, 2001), which "revised the policy and guiding principles of the Legislature relating to education governance" and created a new state Board of Education abolishing among others the State Board of Community Colleges (s.229, F.S.) Florida's SB1162 passed during the 2001 legislative session and overhauled Florida's educational governance. SB1162 created a new Board of Education with a Commissioner appointed by the Governor. Among other things it abolished the State Board of Community Colleges and transferred all of the powers, duties, functions, personnel, and responsibilities to the newly formed Florida State Board of Education. As a result of this legislation, the new State Board of Education and appointed Commissioner of Education became effective January 7, 2003. The Commissioner of Education is one of six members of the Governor's Cabinet. The Commissioner of Education, upon recommendation by the Governor, is now appointed by the Board of Education as compared to having previously been an elected official. The Commissioner of Education and State Board of Education are responsible for overseeing the seamless education system that governs 
Florida's K-20 education system. The Chancellor of the Florida Community College system, formerly identified as system director, reports directly to the Commissioner of Education. Despite the massive overhaul of Florida's education governance system, the governance structure of the twenty-eight local governing community college boards of trustees appointed by the Governor, locally selected presidents by the board of trustees, and state-level oversight through the Chancellor's office continues to remain intact.

As part of this statewide governance reorganization, the Board of Education was tasked with developing a $\mathrm{K}-20$ Performance Accountability System. Statutory Goals were established around four primary goals, "highest student achievement, student articulation with maximum access, skilled workforce and economic development and quality efficient services" (229.007, Florida Statute, 2000).

\section{California System Interview Data}

Five individuals were interviewed at the California Community College system level. The individuals included the Chancellor and a member of his staff, a Legislator, a Board of Governors Member and a faculty representative serving in statewide faculty leadership. This section details information provided by interviewees in response to 
questions regarding California's mandated shared governance process and how the state is addressing increasing demand for performance outcomes in an environment of decreasing resources. The data collected are keyed to the study's four research questions.

\section{Research Question One}

What is the governance or decision-making process used for community colleges in each state as described by key stakeholders?

All five participants at the system level identified the consultation process as the primary means by which decisions are made for the CCCS. Chancellor Nussbaum described the decision-making process for the California Community College system as three distinct arenas. The first arena is where decision-making by the state Legislators and the Governor occurs after receiving recommendations from the system leadership. The second is at the system level whereby through the consultation process the BOG makes decisions and the third involves local decision-making at each community college. All participants were extremely familiar with AB1725 and its mandated consultation process, which requires the BOG to consult with representatives before adopting policy. One faculty participant clarified further by commenting that 
AB1725 and Title $\mathrm{V}$ basically provided additional powers to the Statewide Academic Senate and the local senates. In addition to the system-wide Consultation Council process, AB1725 established standards identified as Academic and Professional (A \& $\mathrm{P}$ ) matters requiring Academic Senate input into decision-making. At the local level, these $A$ \& $P$ standards require the local senate to be consulted before decisions are made. A governing participant pointed out that California's statewide decision-making process is "extremely complicated and cumbersome" because there are over 2000 statutes that "direct the activities of local districts." As one executive participant put it, "there is a great deal more micro-management [by the Legislature] of the colleges than in any other state." This is seen as relevant because changes to existing rules have to go through the legislature. This executive participant continued by saying "we have a history of extensive policy making by the legislature and the Governor, which constricts the ultimate governance authority of the BOG and local districts."

All participants concur that shared governance is slow and time consuming but some emphasized the significance of the inclusiveness of the process to adopting policies that would be accepted throughout the system. A governing 
participant voiced concern that due to the tediousness of the shared governance process, CCCS appears to move slower with regard to decision-making than does the UC or CSU systems. When asked whether all legislators see the mandated consultation process as having hindered or enhanced the system's ability to address accountability, a governing participant stated, "I don't think most legislators have any grasp of it [i.e., shared governance through the consultation process]."

Another governing participant is of the opinion that to date there has not been an "orchestrated system for making decisions" that affects the system at the statewide level but also voiced ignorance of how shared governance worked at the local level,

I would hope maybe their decision-making is less cumbersome. But what we have is a dynamic interactive system that has generally not shown any cohesive, strategic plan for movement to accomplish particular goals or priorities.

This governing participant also voiced concern that the system was too reactive because of the lack of longrange plans. According to this participant, that coupled with rotating constituency representation results in a system that does not have a coherent decision-making process. As stated by this participant, 
We have a bunch of different players involved in a complicated process. Decisions end up being made based on what are perceived as the most immediate needs or priorities for one or more of the players in the system.

Furthermore, this governing participant described the CCCS as a "bastardized structure" as a result of its outgrowth from the K-12 system. Expressing concern that the system "doesn't place an entity in a position of commanding authority and respect." This participant described it as a "piecemeal, patchwork system with every player trying to maintain his/her own level of influence and authority."

With regard to the consultation process, the Chancellor and other executive leaders emphasized that while the Chancellor attempts to reach consensus prior to bringing recommendations to the BOG, in fact, mandated shared governance doesn't require consensus. One executive further clarified by saying that "there is no statute that uses the word shared governance" and that "some people get hysterical" when this distinction is pointed out. The executive continued explaining that "the term shared governance is what some members of our system wanted to see in the statute but it is not language that was adopted in the statute." When asked to define shared governance, an executive participant explained that $A B 1725$ requires the 
BOG and other system leadership "to consult with institutional representatives and seek the review and comment of organizational representatives before adopting policy. That is consultation."

Finally, participants were asked how shared governance works at the local level. According to an executive participant, "governing boards are required to ensure that faculty, staff and students have the ability or opportunity to participate effectively." However, all participants concurred that shared governance at the local level varies from district to district depending upon the leadership of the institution.

\section{Research Question Two}

What effect, if any, did the governance process have on the development of the accountability measures and performance-based funding initiatives currently in existence (PFE) as perceived by key stakeholders?

The five system participants agree that CCCS has been and continues to be, under-funded. PFE was seen as a means of attracting additional revenues to the CCCS. The Chancellor defined the challenge regarding additional funding in this manner

My sense was that if we were going to achieve more money, better levels of funding, that we couldn't just go into the legislature with the mantra we are under-funded. We deserve more money. We had to tell the legislature and the Governor what would change. 
What we needed the money for and what would change if we received better funding.

The Chancellor perceived the CCCS as doing well with respect to access but not with regard to student success. Therefore, the Chancellor and his staff determined the best approach to obtain additional funding was to focus additional revenue on increasing student success outcomes as illustrated by successful student completions, transfer and Associate degrees awarded. The five system participants recalled that the idea of additional funds tied to outcomes "was totally attacked from every group within consultation." They shared the perception that consultation members felt student outcomes should not be addressed with any request for additional funds but that the system should simply ask for more money to compensate for the insufficient funding. As recalled by several executive participants, the response was "We don't want to talk about performance funding or accountability in any way, shape or form and they basically said, no. Every group."

The Chancellor and other executive participants believe accountability measurements would have been imposed as it had been in other states. Therefore, they proceeded 
irrespective of the resistance. As one executive

participant described the development of $\mathrm{PFE}$,

I would describe it as originating in an

interest in improving the average dollars of FTES

that we get in our system compared to a national

average. And as a way of effectively

communicating the level of under-funding and a way of ensuring the legislature that we were serious about student outcomes. It was a way of mirroring an interest of theirs with an interest of ours.

\section{Research Question Three}

What differences, if any, exist within each state's governance process to indicate any possible impact on how each state is addressing accountability and performancebased funding?

The following additional findings related to participation, the economy and accountability are presented in an attempt to identify the differences between the two state's governance processes. The differences between the two states are further illustrated in Table 4.

The five system participants were asked how the shared governance process impacted California's attempt to address the issues of accountability and performance outcomes tied to funding. A faculty participant described the concept of shared governance as being very important to faculty while not as appreciated by administrators because it takes more effort to come to agreement and eliminates administrators' 
flexibility. According to this faculty participant, the shift in local funding due to Proposition 13 along with the program-based standards established in AB1725 was the impetus for the notion of participatory and shared governance.

The Chancellor described participation as "bi-lateral" in nature in terms of policy recommendations when describing shared governance practices at the local level. He illustrated this by addressing the issue of grading policies, which clearly is of vital interest to students. However, because it is an Academic and Professional matter, under the terms of $\mathrm{AB} 1725$, the board of trustees will either mutually agree with or rely primarily upon the Academic Senate without necessarily involving students in the discussion or decision.

While all agreed the current process was not without its flaws, the previous process was described as problematic in terms of the quality of decisions made. One executive participant illustrated this when describing the problems of the structure prior to AB1725 and its mandate as,

A policy issue would be discussed by each of the separate seven councils, all of who had their own meeting schedule. The Chancellor's cabinet folks would all trot around and talk to the individual councils and the thing would start 
changing so each council was in effect discussing a slightly different version of the thing.

According to this executive participant, under the current consultation structure every group is looking at and discussing the same document at the same time across the table. Furthermore, all five of the system participants agreed that consultation, if it works according to intent, allows for a forum by which a variety of opinions can be exchanged. It was agreed that consultation does not guarantee consensus and that while it was critical to the success of an initiative to work towards consensus, consensus was not always possible. An executive participant summarized mandated shared governance as being cumbersome because of the number of individuals involved and the complex organizational structure of CCCS. Concluding with the statement that, "we have a huge, huge mandate and a very small staff to carry out that mandate."

All five state level participants perceive the CCCS as grossly under-funded with several economic state issues limiting the funds available for public programs. Examples given included the utility crisis and homeland security among others as having contributed to major shortfalls in the statewide budget. Also, it appears as if PFE will be affected and would likely disappear or at least not be 
funded for a year or two. Another area of concern involves the large influx of students expected into the CCCS over the next decade due to the population growth forecast for California. Furthermore, it is anticipated that this growth will reflect the growing diversity in the state's population. One governing participant spoke of the expected growth in students and the need for additional funding and described the community colleges as, "much more economically viable because it costs taxpayers considerably less to educate students in the CCCS as compared to either the UC or CSU systems."

With regard to accountability, one executive participant responded that it doesn't necessarily mean being tied to funding, "We are being held accountable if the results of our work are simply being held up to public scrutiny." Most system participants believe that the emphasis has previously been on inputs (e.g., full-time to part-time faculty ratio) rather than outputs (i.e., student transfers and completions). The biggest fear of the executives participating in the study was that performance measures would be imposed as they had been in other states affecting not just a portion of the budget but the whole budget. One executive participant illustrated the importance of consultation stating that without it 
decision-making about accountability would "be in fewer hands." Another concern addressed the issue of Governor appointed BOG members possibly reflecting the perspective of the Governor making accountability potentially even more political.

While addressing issues of accountability, one executive participant stated that CEOs and administrators generally prefer that the board and Chancellor's office not intrude, impose or regulate. In contrast, this executive perceives the faculty as wanting more intrusion and regulation as illustrated by the following statement:

The faculty groups tend to want the state to intrude more in certain areas, particularly around how funding goes out and what it is targeted for because they want the Chancellor's office and the board to impose more on the local colleges so that local boards and leadership are prevented from making decisions that faculty might not agree with.

However, governing and executive participants emphasized the fact that the ultimate decision-making responsibility of the system and colleges rests with the BOG, local boards and CEOs.

\title{
Research Question Four
}

\author{
How has the states' governance process impeded or \\ advanced the formation and implementation of the \\ performance-based funding process (PFE) as perceived by key \\ stakeholders?
}


According to executive participants, consultation played a huge role in advancing PFE. It was noted that the measures, goals, contingent funding mechanism and every component of PFE went through consultation. However, one governing participant, while agreeing that PFE would not have occurred without consultation, concluded that consultation impeded the implementation of a more effective system for actually measuring outcomes.

When asked why consultation may have impeded the process of establishing an effective performance program, this governing participant said it was because of the "proprietary aspects" of consultation in protecting areas of interest or "turfs" of the various constituencies represented. This same participant perceives the current Governor as being less frugal towards community colleges and more interested in providing flexibility to the system while expecting advancements in accountability.

When asked whether or not PFE has been successful in addressing accountability issues for CCCS, participants agreed that it was too early to tell. According to one executive participant, "unfortunately, we have been forced into a situation of reporting results before it is really reasonable from a research point of view to say that this funding was causative in these results." Most participants 
expressed a belief that some of the outcomes tied to PFE would have happened regardless of $\mathrm{PFE}$ funding. As one faculty participant responded, "when you do a linear study in five or six years you may discover that PFE was a great success but of course it will probably be gone by then."

\section{Florida System Interview Data}

A total of 11 individuals participated at the system level. The individuals included the Chancellor (previously known as "Director"), members of his staff, two legislators, a member of the Board of Governors, a state employee of OPPAGA (Office of Program Policy Analysis and Government Accountability), a Florida State University faculty member with extensive policy experience for the FCCS and an administrator of FACC (Florida Association of Community Colleges). This section details information provided by interviewees in response to questions regarding Florida's decision-making process and how the state is addressing increasing demands for performance-based accountability. The data collected are keyed to the study's four research questions.

\section{Research Question One}

What is the governance or decision-making process used for community colleges in each state as described by key stakeholders? 
The 11 Florida system participants agree that a collaborative or collegial approach is used for system-wide decision-making. One executive participant described the process as "a rather complex but very workable system" with approximately eight standing councils. Another described it as a process where an issue comes up through the various standing committees usually in the form of a "white paper," which presents the issue under discussion. The "white paper" is then changed or modified or a sub-committee is appointed to examine the issue. When asked if there were faculty or staff representation on councils, one participant responded, "Overall the committee structure tends to be either Deans or Department Chairs so they tend to be a little higher than faculty." After a particular council votes on the issue, they make a recommendation, which is then referred to the FLCCS and Presidents' Council. The Council of Presidents consists of the 28 college presidents. According to an administrative participant, the Presidents' Council, state Board of Education and FACC then try to reach agreement before making a recommendation to the Legislature. The agreement process was described as "one of consensus building using a collegial approach." When asked to define consensus as used in FLCCS'S statewide decision-making, one executive 
participant defined it as compromise but the others defined it as "where all are given an opportunity for input to an issue through the system's eight standing committees." Agreement is not a requirement but the intent is that all involved agree they "can live with" the outcome.

The 11 participants perceive the legislators as "very involved" but stated that the FLCCS has a history of working very well with the Legislators, who are described as possessing a lot of power with regard to community college governance. In addition, all participants perceive Florida as being in a transition phase due to the Governor's recommended educational governance model adopted by the Legislature. The impact to community colleges is expected to be minimal with FLCCS's structure of local governing boards having authority and responsibility for college decision making to be used as a model for all other state educational systems. One governing participant said, "I am very proud of the fact that the community college model is really the model for the whole new system of governance."

When asked how the new state governance model would impact Florida's community colleges as a system, one faculty participant believes the changes to the community college system will be minimal. This was further 
illustrated by acknowledging that even though the state Board of Community Colleges was being eliminated the Division of Community Colleges' staff would continue to provide assistance and guidance to the new state Board of Education. However, this faculty participant perceives some impact from the reorganization in that while colleges will continue to have influence over academic programs at the institutional level, "I think there will be a critical approval function at the state level." Participants were generally positive about the reorganization; however, three participants expressed a "wait and see" attitude as to what the final effects would be. A governing participant described the biggest advantage of the new governance structure as an opportunity to focus state resources to best meet the needs of students because a "single budget for all of education will be submitted to the legislature." When asked to describe the decision-making process at the college level, all agreed it varied from college to college. There was agreement that campus constituency involvement is dependent upon the CEO's leadership style and the local governing boards. All of the system participants see the responsibility and authority for Florida community colleges as predominately resting with the local governing boards. When asked about authority for 
decision making, one faculty participant responded, "I would say that presidents have fairly significant authority depending upon the relationship they have with their local boards." One administrative participant said that community college local boards controlled institutions in terms of decisions about management and how to use accountability and performance to make decisions. One governing participant described how information regarding decisionmaking currently came from the local level to the state board as "most of the information is brought to us from the Division of Community Colleges staff. Some of it because it is statute and some of it because it is in rule of things we have to look at or review."

When asked if faculty and staff participate in decision-making at the state level, one executive participant said they are represented primarily through FACC, Florida Association of Community Colleges. Based upon this statement, a FACC executive was contacted and the FACC website visited to learn more about the organization. As a result of reviewing FACC's website information, it was found that FACC is a professional association formed in 1949 in an effort to unite the state's public community colleges. It is funded through institutional dues and its 7,008 individual dues paying members represent all 
community college employees. According to FACC's website, it represents all "twenty-eight community colleges, the Division of Community Colleges, their Boards, employees, retirees, and associates" (FACC website:

http://facc.org/general.htm, Mission Statement, February 6, 2003). A FACC administrative participant was identified to participate in the study as a result of the referral. According to this participant, the Council of Presidents and the Division Office of the State Board of Community Colleges work very well with FACC attempting to get agreement, which is then advocated to the legislature.

\section{Research Question Two}

What effect, if any, did the governance process have on the development of the accountability measures and performance-based funding initiatives currently in existence $\left(P B^{2}\right)$ as perceived by key stakeholders?

An interest in educational accountability is primarily attributed to the increasing demands for state resources and concerns regarding time to degree completions. According to several governing participants, the legislators and public perception was that students were not moving through the Florida education system efficiently. It was felt that the education system wasn't accommodating the needs of students and that a more 
integrated and seamless system of $\mathrm{k}-20$ was required. Four executive participants believe the legislators need data to drive dollars when considering funding decision-making.

There was agreement among all of the participants that the decision-making process used in the state allowed for extensive input into the actual accountability measures adopted for the FLCCS. According to one administrative participant there are a total of five accountability measures identified in $\mathrm{PB}^{2}$ :

- A.A. degree completers

- Special category measurements (college prep for remediation and disadvantaged students)

- Workforce placements and transfers

- A.A. efficiency measurements (completing an A.A. degree in 72 hours or less)

- College prep measurements (how many student completers are in the highest level of college prep in Math, Reading and English.)

The executive participants perceive the measures as having been developed collegially by involving "a lot of people" and taking over a year to develop. $\mathrm{PB}^{2}$ accountability measures were advanced through the Presidents' Council and communicated throughout the state via several workshops. According to the Chancellor, "if the process hadn't involved a lot of people, it probably wouldn't have been as successful." All 11 participants agreed that $\mathrm{PB}^{2}$ was a means of acquiring more money for the 
system and it was in the best interest of students and the FLCCS for the colleges and system to work with the legislators to develop its own accountability measurements. System participants mentioned the fact that the legislators had moved all state agencies into a performance-based budgeting program as a result of the 1991 Accountability Act. Therefore, it wasn't a question of whether or not accountability tied to student outcomes was an issue but rather what measurements would be used to evaluate community college performance. According to the Chancellor, "we saw it coming so we developed our process." Community colleges had been slated by the legislators as the first education system to join the process. When asked why community colleges were the first of the educational institutions in the state to adopt $\mathrm{PB}^{2}$, all participants cited the "responsiveness of community colleges to react quickly" and the existing community college data available to move to accountability measurements and evaluation as compared to other education systems as a reason why the FLCCS was chosen.

According to an administrative participant from OPPAGA (Office of Program Policy Analysis and Government Accountability), contrary to general knowledge, there are actually two types of performance-based budgeting in $\mathrm{PB}^{2}$ or 
as it is also referred to, PBB. This administrative participant clarified by explaining that to every other state agency $\mathrm{PB}^{2}$ is a process whereby measures and standards are developed between the agency and the Governor's office. According to this participant, performance-based budgeting by definition consists of "measures, standards and legislative review." He further stated that $\mathrm{PB}^{2}$ has been in existence in Florida since 1994 but community colleges didn't come on board until about a year later. Furthermore, according to this administrative participant, community colleges are really operating under performance-based funding not performance-based budgeting. Performance-based funding is a point driven system where points are identified for each of the accountability measures with a dollar value assigned to each point. Annually the legislators assign the dollar value and then based upon data, community colleges receive additional funding as a result of achieving specific performance criteria.

According to this administrative participant, $\mathrm{PB}^{2}$ was adopted by community colleges to include the five accountability measures developed collegially by the system and they were funded based on the $\mathrm{PB}^{2}$ point allocation. However, measures and standards fell apart system wide but 
the "point driven pot of money" continued to exist. According to this participant, "The Legislature was concerned that community colleges were only tied to performance-based funding and not budgeting." However, he said that this "wasn't the fault of community colleges because legislative staff made the decision to just go with the performance funding pot." All 11 system level participants see the performance funding pot as having been beneficial for the FLCCS. It has brought additional money into the colleges, even though small as compared to the entire budget, while holding institutions accountable for student outcomes.

\section{Research Question Three}

What differences, if any, exist within each state's governance process to indicate any possible impact on how each state is addressing accountability and performancebased funding?

A comparison of the two states at the system and college level is presented in Table 4. The following findings are presented in an attempt to identify additional data related to Florida's decision-making process in addressing accountability and performance-based funding. When asked to address the state versus local role of decision-making, an administrative participant perceives the system office as having a limited role with respect to 
aspects of community college decision-making, particularly regarding accountability issues, because the control is at the local level. He illustrated this when he said, "the FLCCS in Tallahassee is the nail but the hammer is at the local boards because in general, decisions are made at the local level." According to this participant, it took three years for the community colleges even to begin using $\mathrm{PB}^{2}$. The reason given that because the colleges are locally governed it is less important, as compared to other state agencies, to have a state level accountability process.

All 11 system level participants identified funding as a concern. While all agree that Florida's community colleges are governed at the local level, the perception is that what is driving accountability statewide is the fact that the money comes from the state without any control over how the money is used at the local level. As one administrative participant stated, "there is a real need for the state to ensure the return on investment is there." One of the most significant impacts identified by all of the participants is the fact that data and planning is now driving decisions. Data are shared system-wide such that "everyone has everybody"s student performance data, student FTE data, funding data." One executive participant described this as "living in a glass house" where the 
"black box" has been removed thus building trust, which is seen as invaluable to working together system-wide. A governing participant said "I have seen more data driven decision making the last few years than ever before and I think that is a really good thing." When asked why, the participant responded that while, "decisions can be made based on feelings or perception, it really isn't a good way to manage." This same governing participant believes educational agencies have not been "very good at demonstrating in a very businesslike manner what they need money for and what more money will do for them."

In addition, with regard to performance funding, an executive participant believes there was initially a lot of uncertainly as to whether or not performance funding was going to penalize or reward. But, once it was obvious that the legislature was trying to "use it to reward not penalize us, we worked very well with the legislature." It was also noted by another executive participant that funding for performance-based budgeting has not been used to drive funding but only to allocate money. When asked about the accountability measurements, this executive participant stated,

They also have a system of what they call accountability measures but they have had no impact on funding at all. In fact, they are a 
waste of time.

All eleven participants commented on some of the cultural changes taking place on community college campuses throughout the state as a result of the emphasis on accountability and performance. An executive participant described a situation where he accompanied a business officer, who happened to be an acting Provost at one of the campuses, on a stroll through the registration area during lunchtime to see several students walking away. Apparently, the business officer asked if there was something wrong and was told the computer was down so students couldn't register. He asked the students to wait and asked the staff "why can't we register students now and then enter them into the computer later?" According to the executive participant, the response was "we can but it is a lot of work." The business officer responded to the staff,

Let me tell you right now, we will never ever turn a student away. They are here on their lunch hour and they are not going to come back. If I ever find out that we have done this again, you are out of a job.

The executive participant stated that he has observed several incidents at colleges where barriers to retention are being removed whether in the registration process, student financial aid processes or faculty attendance 
regulations. This executive participant attributes this system-wide change to an emphasis on accountability,

When business officers begin to really think about what goes on in the classroom, to care about students. You have really changed some attitudes and behaviors. $\mathrm{PBB}$ has done that. According to the system Chancellor, there are many "incidental kinds of things going on at institutions that are being cleaned up" as a result of the performance focus. For example some colleges, which previously charged graduation fees, described as basically a cost for printing diplomas and other such related matters, have discontinued the fees. These additional fees were identified as a discouraging factor to some students resulting in their not applying for graduation. It is believed that the emphasis on outcomes has removed such administrative barriers along with other significant changes with regard to time to complete and success factors.

System participants who addressed faculty involvement in decision-making saw it as being more likely to be relevant at the local decision-making level. An administrative participant stated that there was a statewide faculty senate organization but it wasn't "formally organized and not active." It was also noted that some statewide faculty representation existed via ad 
hoc committees charged to deal with specific issues for the system. An example given: librarians or counselors addressing issues related to respective areas of responsibility. When asked what faculty's response has been to the emphasis on performance outcomes and whether or not there has been resistance to the concept, one administrative participant said,

I think they had the heads up that the changes were going to happen. I think there was probably not a lot that they could do to influence the process. I think the train was on the track.

Another area addressed by all of the system participants was related to workforce development. All of the governing participants spoke to the need for a business model for education, which is more "market driven." A governing participant sees life-long learning as the most important piece of education's continuum, citing advances in technology as having affected industries such as the space program, where engineers, scientists and technicians need to continually be trained. System participants perceive community colleges as being responsive to industry because they work so closely with the businesses in their community, which was further illustrated by a governing participant when he said, 


\begin{abstract}
If the business community decides that all of a sudden they need training, whatever it may be, the community colleges are very good at responding by creating effective programs.
\end{abstract}

With regard to community college funding, there were some differences of opinion. One governing participant voiced optimism for future funding for FLCCS because the House and Senate leadership "are very aware of how effective community colleges have been and how under-funded they are, by the way." This same governing participant went on to say,

One of my regrets is that when we started this performance-based budgeting stuff, we said okay we are going to give you money for success. I always envisioned that the money would be recurring. If you did something right, you earned the money. As long as you didn't screw up later, you would keep the money.

This participant believed this would be an incentive for the colleges to continue to do better. Unfortunately, according to this governing participant, the colleges weren't given the money promised because "the legislature didn't keep its side of the bargain."

When asked about community college funding, another governing participant stated, "There is very little existing evidence to indicate that we are not able to perform as a system because of money." Another governing participant criticized current funding formulas stating, 
There is no relationship between the full price of education and what is charged so nobody in the system thinks about the value for the dollars received. There is no return on investment mindset within public education because it is all formula driven.

\section{Research Question Four}

\section{How has the states' governance process impeded or advanced the formation and implementation of the performance-based funding process $\left(P B^{2}\right)$ as perceived by key stakeholders?}

All agreed that the statewide discussions conducted by the accountability task force and the efforts of the Presidents' Council provided opportunity for extensive input into the formation of the accountability measurements tied to $\mathrm{PB}^{2}$ for community colleges. The measures were described as being quantifiable and attainable. $\mathrm{PB}^{2}$ is not seen as having been very successful except for the fact that it has placed an emphasis on student outcomes. Governing, executive and administrative participants believe that more money should be put into performancebased funding in order to truly make it incentive based. One administrative participant said, "the funding system is broke, not the performance piece." 


\section{College Interview Findings}

A total of 13 individuals participated at the college level: seven at West College in California and six at East College in Florida. The individuals ranged from faculty members, currently or previously serving in leadership positions, senior and mid-management administrators, a trustee, and the current college president.

\section{West College Interview Data}

Research Question One

What is the governance or decision-making process used for community colleges in each state as described by key stakeholders?

All seven of West College's participants were aware of the passage of the mandated AB1725 "shared governance" legislation; however, impressions of the significance of "shared governance" varied slightly depending upon stakeholder position within the organization. One executive criticized AB1725 and its subsequent changes to Title 5. This participant stated that Consultation Council, as mandated by AB1725, has been a "disaster for the CCCS because service on the council is based on constituency representation rather than college or responsibility representation." Further criticizing shared governance through the consultation process as too cumbersome and 
giving "too much power or say to organizations rather than colleges." According to this executive, "They [the colleges] are being represented by some group who is not responsible for anything." A governing participant echoed this concern expressing a perception among governing and executive leadership throughout the state that

There is an over balance of faculty representation on all of the major committees and it is hampering their ability. There is participation without accountability. It is the leadership, not the faculty leadership but the management leadership, the administrative leadership that are ultimately accountable.

An executive participant commented on a lack of collective system prioritization, which has subjected the CCCS to a lot of criticism from the governor and the legislature. The legislators "think we take much too much time to come to decisions and we are afraid to make decisions, to prioritize. We submit a budget and don't prioritize." With regard to shared governance at West College, there appeared to be general agreement among all of the participants that it worked fairly well but that it was a slow, tedious process. The faculty participants acknowledged that they understood the shared governance process at their particular college but had limited knowledge of the statewide consultation process. When asked 
to define shared governance, a faculty participant identified it as a structure where the college administration is required to ensure that faculty are provided opportunities to assist in decision making processes at the college. The faculty participants see shared governance as having strengthened faculty involvement in local decision-making. However, all college participants agreed that while AB1725 mandated the concept of shared decision-making its implementation varied from college to college throughout the state depending upon the individual college's leadership.

With regard to West College's decision-making process, one executive believed the former CEO and the governance structure developed under his leadership tenure indicated a commitment to the philosophy of shared governance.

However, upper leadership, not necessarily the CEO, didn't have a grasp of planning concepts so a lot of good information was discussed but there was never any impetus to carry out into some action plans.

While the structure exists for shared decision-making at West College, this same executive participant felt that there were lots of effort, good ideas and input but the "fruition of the plan was never there" making the organization ripe for a change in leadership. 


\section{Research Question Two}

What effect, if any, did the governance process have on the development of the accountability measures and performance-based funding initiatives currently in existence (Partnership for Excellence (PFE)) as perceived by key stakeholders?

All of the participants concurred that PFE represented the state's first attempt at addressing educational

accountability. As noted by one executive participant, "Up until PFE, I don't think there has been any attempt to have accountability other than fiscal accountability." However, this same executive participant stated, "I think through this shared governance process at the state level there is a tendency not to want accountability." This sentiment was reinforced by all of the executive and administrative participants. The perception is that because of the broad constituency representation on the council there is a tendency to have to "sell an idea" making the process more political than participatory. There was general agreement that $\mathrm{PFE}$ was not really an attempt at educational accountability but merely a quest for money for the significantly under-funded CCCS. All of the West College participants agreed that while PFE came through the consultation process, some thought it "was bullied through" by Chancellor Nussbaum and his staff because it was felt that the only way to get additional funding for the CCCS 
was to tie it to accountability. It was however noted that this was one of the few times that the Chancellor and his staff had taken such an approach.

\section{Research Question Three}

What differences, if any, exist within each state's governance process to indicate any possible impact on how each state is addressing accountability and performancebased funding?

This research question addresses the differences between the two states, which is presented in Table 4. The following findings are presented as they represent additional data with regard to issues of shared decisionmaking, accountability and student performance.

Because California has a mandated consultation council process, all agreed that any decisions made for the system must be run through the representative council before it is implemented. Therefore, the Chancellor and his staff had to bring the PFE initiative addressing accountability and performance funding tied to student outcomes to the Consultation Council. West College's participants perceive this as having had the advantage of presenting a systemwide voice. Executive and administrative participants agree that Chancellor Nussbaum works very hard to get all 108 colleges to speak as one voice to avoid individual districts running to the legislature with 108 different 
requests. According to one executive participant with so many voices in the system with conflicting ideas and proposals, "It is easy for the legislators to ignore us because we don't speak with a common voice." The perception is that PFE spoke with a common voice but that Chancellor Nussbaum worked hard to keep the disagreements at the Consultation Council instead of at the BOG or legislative level.

All of the participants addressed the fact that the CCCS is grossly under-funded. One executive participant stated, "We are under-funded. Look at all of the other states. We are at least $\$ 2000$ under the average of the national community college per student funding." Another concern voiced related to funding as a result of Proposition 13, which allowed for different funding formulas among colleges within the CCCS. According to an internal communiqué of West College, the highest funded district receives $\$ 8,209$ per full-time equivalent student, and the lowest funded district receives only $\$ 3,516$. This was seen as an inappropriate and unfair allocation of state resources. Therefore, West College participants perceive that the system Chancellor and staff felt the only way to get additional funding for CCCS was to look at accountability measures tied to student performance 
outcomes. Faculty participants while not against accountability per se, voiced concern about the emphasis on rewarding colleges with money tied to meeting quantitative goals. As one faculty participant stated, "I think it is a good idea to have some sort of accountability. I think anytime you don't review and hold people accountable, then things tend to stay the same or get worse." However, there was disparity in how governing, executive and administrative participants interpreted educational accountability versus faculty participants' views. All of the faculty participants described educational accountability as maintaining professional standards through such processes as institutional review, faculty professional development, and tenure and evaluation. As one faculty participant commented,

I think the faculty see incongruence or discountenance or whatever you want to say between what we really feel is best educationally for students and what administration has to be accountable for as far as costs and things like that.

\section{Research Question Four}

\section{How has the states' governance process impeded or advanced the formation and implementation of the performance-based funding process ( $P E E$ ) as perceived by key stakeholders?}

Several executive participants noted that the only new funds allocated in recent years to the CCCS have been from PFE. All seven of West College's participants agreed that 
PFE was the "brainchild" of the current Chancellor or his key leadership. The perception is that PEE was "sold" on many levels throughout the system as the only means of infusing additional revenues into the system. As one administrative participant noted, the CCCS was "running up against a wall in terms of trying to get money." The perception is that $\mathrm{PFE}$ represented an attempt to respond to the call for more accountability concerning student outcomes. However, participants agreed PEE was not really an attempt at educational accountability but merely a response to a quest for additional funds. When asked if $\mathrm{PFE}$ has been successful in addressing educational accountability, one respondent replied "probably not because there really hasn't been improvement." To quote one administrative participant,

I guess we are accountable in keeping up at least at the same rate of success we had before but I am not sure that it has done much to increase performance. Probably, it has made us more accountable but it hasn't really improved our performance.

And a governing participant stated, "PFE has been a source of additional income but it has also been a source of bureaucratic hoops we have had to jump through and that is a disappointment." This governing participant believes that any improvement in student outcomes is because of 
capable educators who want to help students succeed and has nothing to do with the infusion of PFE funds.

While all agreed that PFE hasn't made significant system-wide outcome improvements, they also agree that it has increased the focus at the college/district level on student outcomes. An administrative participant noted that the current accountability measures such as transfer to the UC (University of California) and CSU (California State University) systems were limited measurements. All college participants perceive the CCCS as having been forced to somehow demonstrate that it was adequately doing its job. The CCCS needs to increase funding but as a governing participant noted, political agendas greatly impact the mission of the CCCS. This was illustrated by commenting that, "I don't know anything about politics but I am seeing how detrimental it is to our mission to educate students." A governing participant believes most faculty are against performance-based accountability because "non-educators are trying to measure education" and faculty do not feel that non-educators should be in control of what happens in the classroom.

When asked how the state level decision-making has impacted educational accountability, one executive participant voiced strong criticism because of the 
constituency representational aspects of the process. The faculty participants acknowledged that they understood the shared governance process at their particular college but had limited knowledge of the statewide consultation process.

\section{East College Interview Data \\ Research Question One}

What is the governance or decision-making process used for community colleges in each state as described by key stakeholders?

All six of East College participants described their college as being in a transitional phase due to recent changes in leadership. The previous decision-making model at the college was described as "hierarchical and autocratic" under the previous president. East college's current governance structure was described as collaborative where issues or problems are identified and plans are implemented to come up with a solution strategy. An executive participant also described the decision-making model as traditional with respect to operations based upon areas of responsibility. This same executive said there was a tendency for "lots of talk and little action" under the previous leadership. The perception of most participants is that the new governance structure at the college was a 
product of several factors. As a result of Title III and $V$ grants, the college began to engage in dialogue about student learning and success. The emphasis on student outcomes and the prospect of obtaining additional funding through performance outcomes along with new presidential leadership were seen as the primary causes for the transition.

According to the faculty participants, the current president was selected by a narrow vote of the governing board. As described by one faculty participant, two candidates were being considered for the president's position by the board "so faculty just crammed into the room." This participant believes the overwhelming presence of faculty was because they were convinced that only one of the candidates would continue to move the learning centered initiative forward. Another faculty participant described the former decision-making process at East College as a "star chamber" model, where the president and a few select administrators made decisions. Budgets were kept secret and faculty were becoming frustrated. This faculty participant said, "we were going to make significant changes or we were heading towards a union or some other form of very unpleasant future." All of the executive and faculty participants voiced a great deal of satisfaction with the 
new president's style of leadership. One executive participant described the president as having an "open style that invites participation and input." Additionally, the perception is that the new president is willing to make tough decisions even if in opposition to recommendations reached through the collaborative process. However, such decisions are communicated with explanations of why and how the decision was made. A faculty participant sees East College as moving towards a more perfect decision-making process but "we have a long way to go."

Furthermore, according to the faculty participants, in addition to being collaborative, the president is seen as clearly understanding the importance of having relationships with the faculty. The president is also perceived by all participants to be very learning centered. The faculty participants see faculty morale having improved drastically as a response to the new president's leadership style. The president was described as "caring, collaborative, learning centered and committed to shared governance." When the president was interviewed for purposes of this study, he used the term "shared governance" while discussing accountability and performance when he said, "In an environment of shared governance, you expect everyone to hold the standards and make them as 
explicit as you can." The president was then asked if "shared governance," describes the decision-making process used at East College. The response was "Yes. However, it doesn't cover nearly the pregnant meaning that it does in California. It just means collaboration so you are more likely to hear the word collaboration."

When asked how decisions were made in committees and councils, all six participants agreed that while efforts were made to reach consensus, the responsibility and authority for the final decisions rest with the president and governing board. When asked to distinguish between collaboration and consensus, a faculty participant said they are different and proceeded to define collaboration as information gathering that may or may not impact a final decision, which ultimately will be made by the President and Board of Trustees. Consensus, on the other hand, was described as the coming together on a final outcome. This was illustrated when he stated,

I guess I view consensus as being kind of an end result. When you reach consensus, there has been in essence a resolution of an issue whereas collaboration is merely the sharing of ideas and information.

When asked whether the governance process at East College was collaborative or consensus building, this faculty participant responded, "On some issues we 
collaborate. On some issues we do consensus" where consensus was defined as basically everyone agreeing with a solution knowing that the decision may not have been their first choice but they can live with it. When asked about efforts to reach consensus at East College, the president talked about the concept of servant leadership with regard to "primus" defined as the person with the most at stake concerning the issue being addressed. The example given: on budgeting issues the Chief Financial Officer is the primus. The president further stated that, "There is a natural and healthy tension between decisiveness and collaboration. Most of the formulations that resolve tension are unsatisfactory, for example, consensus." The president believes that the pressure to create consensus results in an unwillingness of people to express their dissent on an issue.

While it is good to have consensus we aren't going to beat ourselves up to get consensus mostly because in a false consensus the results are that $70 \%$ of the people agree and the other $30 \%$ are too embarrassed to disagree.

Participants perceive the current president as having brought a principled style of leadership to the college. Several executive and faculty participants described the president's style of leadership as one of "servant 
leadership" referencing Robert K. Greenleaf's (1977) work entitled "Servant Leadership".

Prior to the new president, we had models dealing with collaboration that we thought as learning centered and outcomes oriented. The guiding sort of overarching concept behind all of the models was collaboration and that was probably the primary theme throughout the selection of our president.

Another executive participant stated that collaborative decision-making requires a process: a process for self-directed management. Participants perceive the new president as attempting to create such a process. Several participants talked about the creation of the College Planning Council that will be tasked with tying planning and decision-making to funding based on the learning centered initiative. One executive participant predicts the new structure "will be open and action oriented" with respect to decision-making. When asked what influences in his career or personal life had brought him to adopt a servant leadership style, the president responded it happened when he understood that "respecting deeply other people's ideas didn't cost anything. I didn't give up any authority when I gave other people influence." With regard to system level decision-making, an executive participant described Florida as being in a state 
of transition with a lot of new presidents throughout the system. Furthermore, according to this participant,

By law, the boards and presidents have immense authority and by tradition they have exercised it. Florida has had a history of, well-tyrannical is too strong of a word--but fairly independent presidents.

With regard to legislative leadership, an executive participant said that "the legislature has no compunction about diving into detailed matters of the life of the colleges and they do it all of the time." While not done on every issue by all legislators, the perception is that Florida has a long history of legislators having a pet peeve and then instead of leaving it to the faculty or administrative leadership to resolve, they "legislate a 6,000 word statute or rule" and it was noted that can be on anything from grading to classes or financial aid policy. When asked if there was a tendency for different colleges to go to different legislators, an executive participant said that had been the case historically though the new presidents have worked very hard to "covenant with each other to work on behalf of the system" believing that it would benefit all in the long run. However, the perception is that the responsibility for this independent behavior rests on the shoulders of the legislators who have caused such behavior and have been unwilling to have a 
rational funding formula for the entire system. One executive participant sees the current governance as weak and the real potential of the new governance model as an opportunity to align the Florida Education systems for example with regard to curriculum and funding. Another executive participant acknowledged that no one really knew what was going to happen with the new legislated governance model.

With regard to involvement of the FLCCS and Division of Community Colleges in decision-making, an executive participant described it as a "moderately low control state organization." According to another executive participant, the system works pretty well overall. This executive participant perceives the legislators as "still learning to make decisions regarding the big issues but I don't see quite as much micro-managing as there was say a couple of years ago." However, when a new Governor is elected it creates paradigm shifts throughout the state because the Governor appoints the statewide board members. When asked how system stakeholders perceive decision-making at the local level, a governing participant stated,

I think overall those stakeholders probably view the decision-making process at the community college level to be fairly efficient. I also think that their opinion is confirmed by the recent changes proposed in governance with 
respect to the Universities where they are basically moving towards the process utilized by community colleges.

Faculty participants were not very familiar with statewide processes other than the fact that there has been a history of legislative involvement in decision-making particularly concerning accountability and performance outcomes.

\section{Research Question Two}

What effect, if any, did the governance process have on the development of the accountability measures and performance-based funding initiatives currently in existence (Performance-based Budgeting $\left(P B^{2}\right)$ ) as perceived by key stakeholders?

Florida legislated the $\mathrm{PB}^{2}$ program tying it to funding by identified and agreed upon accountability measures for all state government agencies. East College participants see the emphasis on accountability and performance as being a direct result of a need for the legislators to address government funding in a time of reducing resources. Most participants were unaware of the history behind the $\mathrm{PB}^{2}$ funding model with the exception of three executive participants, one of whom is the college president. One executive admitted ignorance with regard to statewide accountability efforts and only became aware upon reviewing the "My Florida" website in preparation for the interview 
with the researcher. This same executive participant stated, "this is pretty good stuff. I actually got very engaged last night."

\section{Research Question Three}

What differences, if any, exist within each state's governance process to indicate any possible impact on how each state is addressing accountability and performancebased funding?

As in previous discussions regarding research question three, the following additional issues emerged concerning how Florida is addressing accountability and performancebased funding. Research question three is more appropriately addressed in Table 4 and the subsequent narrative summary of recurring themes. During a discussion about educational accountability, a governing participant was asked whether or not educational accountability was synonymous with student outcomes. The participant replied that it was the colleges' responsibility to make sure that students master subjects. This was further illustrated when he said,

If we make any other measures other than student outcome a measure of success then to some extent I think you have relegated the student, which our system is intending to try and keep in the forefront, to some other place. If their success is not what we are measuring our success by, then the student I don't think is any longer the focus. 
An executive participant defined educational accountability as "achieving extraordinary results with ordinary students, ordinary meaning the whole spectrum." However, this participant would like to see accountability mean "where the college holds itself accountable publicly based on specific achievement of learning gains."

All of the East College participants mentioned a cultural shift at their institution with regard to accountability as having happened about six years prior to hiring the current president as a direct result of its Learning Centered Initiative. Participants all perceive student learning to be a significant part of East College's culture. An executive participant described the paradigm shift as having emerged from several grants, which brought together administrators and faculty to discuss and explore among other things, the literature on retention and performance.

Furthermore, it was reported that this shift is further evidenced by the college's commitment in its SAC self-study for accreditation to incorporate core competencies into all curriculum. The executive participant defined the core competencies as, "think, value, communicate and act," which are more "global in nature than the seven very disciplined specific 
competencies." This same executive believes that while the culture of the organization has embraced student centeredness, having a president as committed to this goal is a crucial element.

Asked what responsibility the legislators had with respect to educational accountability, an executive participant responded that "they need to make sure reporting is open to the public." Additionally, whatever measures have been agreed to, regardless of how simple or complex, that a picture is painted to reflect attainment of the public's return on investment. "I think the fundamental responsibility of the state and the public is to define with the institutions what are the outcomes we are after and make them public."

\section{Research Question Four}

How has the states' governance process impeded or advanced the formation and implementation of the performance-based funding process $\left(P B^{2}\right)$ as perceived by key stakeholders?

Funding was an issue addressed by all six of the participants at East College. According to two executive participants, East College is one of the lowest funded districts in the state of Florida ranking about $26^{\text {th }}$ out of the 28 districts. All of the participants expressed the opinion that East College has performed quite well with 
respect to accountability measures. However, $\mathrm{PB}^{2}$ has not resulted in any significant funding increases to the college. According to an executive participant, $\mathrm{PB}^{2}$ hasn't been effective because it never increased East College's funding it merely redistributed about 15 cents out of every dollar from a fixed set of funding resources. In addition, it was noted by all six participants, that East College is experiencing rapid growth in student enrollments. One executive participant said unfortunately, "a model has been adopted in Florida that gives every institution funding even those with declining enrollment." The executive participant attributed this to a combination of factors including the fact that legislators tend to protect the interest of their local constituencies. There is also the perception that those district presidents where enrollment is flat have influenced the state Board of Education and the FLCCS Division office by arguing that they need to maintain current funding if they are to be able to grow in the future.

One executive participant sees funding as an issue of fairness versus equitable funding model. Defining a fairness model, "as being where everybody shares and an equitable model, which says if your college is growing faster than others, you should be funded accordingly." 
According to this executive participant, several system presidents including East College's president made a commitment with the system Chancellor that if the division staff would support an equitable model rather than a fairness model they would not lobby their individual legislators but stay united within the system.

\section{An Analysis of California's and Florida's Systems and Colleges by recurring themes}

Several themes recurred as data were analyzed at the system and college level. Table 4 represents a summary of the recurring themes emerging from the data for each state at the college and system level. The themes are reported in alphabetical order. Some themes are unique to a college, a system or to a variety of combinations and are identified by an " $\mathrm{X}$ " in the appropriate column. The analysis column briefly summarizes the preceding narrative discussions for each college and system. Conclusions and discussion regarding this data as discussed in Chapter 5. 
Table 4: Comparison of the California (CCCS) and the Florida (FLCCS) and Community College System. And the West College (California) and East College (Florida) findings:

\begin{tabular}{|c|c|c|c|c|c|}
\hline Themes & $\operatorname{cCcs}$ & WEST & ELCCS & East & Analysis \\
\hline Collaboration & & & $\mathrm{X}$ & $\mathrm{X}$ & $\begin{array}{l}\text { Florida described its } \\
\text { decision-making } \\
\text { processes as being } \\
\text { based upon input and } \\
\text { collaboration. East } \\
\text { College also uses the } \\
\text { term shared } \\
\text { governance but } \\
\text { synonymous to } \\
\text { collaboration. }\end{array}$ \\
\hline Culture & & & $\mathrm{X}$ & & $\begin{array}{l}\text { Common visions and } \\
\text { principles impact } \\
\text { organizational } \\
\text { culture. }\end{array}$ \\
\hline $\begin{array}{l}\text { Data driven } \\
\text { decisions }\end{array}$ & $\mathrm{X}$ & & $\mathrm{X}$ & & $\begin{array}{l}\text { Planning should be } \\
\text { driven by data. }\end{array}$ \\
\hline $\begin{array}{l}\text { External } \\
\text { influences }\end{array}$ & & $\mathrm{X}$ & & $\mathrm{X}$ & $\begin{array}{l}\text { Term limits can } \\
\text { result in varying } \\
\text { political agendas. } \\
\text { Self-imposed } \\
\text { accountability } \\
\text { measures are more } \\
\text { likely to be } \\
\text { successful as } \\
\text { compared to imposed. }\end{array}$ \\
\hline Focus & $\mathrm{X}$ & $\mathrm{X}$ & & $\mathrm{x}$ & $\begin{array}{l}\text { Emphasis on } \\
\text { accountability \& } \\
\text { performance has } \\
\text { resulted in more } \\
\text { focus on student } \\
\text { learning \& missions. }\end{array}$ \\
\hline Funding & $\mathrm{X}$ & & $\mathrm{X}$ & $\mathrm{x}$ & $\begin{array}{l}\text { Community colleges } \\
\text { are not adequately } \\
\text { funded. }\end{array}$ \\
\hline Leadership & $\bar{X}$ & $\bar{x}$ & & $\mathrm{X}$ & $\begin{array}{l}\text { Leadership style } \\
\text { perceived as } \\
\text { critical. Impacts } \\
\text { every aspect of } \\
\text { organization. }\end{array}$ \\
\hline $\begin{array}{l}\text { Responsibility } \\
\text { and authority }\end{array}$ & & $\mathrm{X}$ & & & $\begin{array}{l}\text { President/boards are } \\
\text { ultimately } \\
\text { responsible and } \\
\text { accountable. }\end{array}$ \\
\hline
\end{tabular}




\begin{tabular}{|c|c|c|c|c|c|}
\hline Themes & $\operatorname{CCCS}$ & WEST & FLCCS & East & Analysis \\
\hline $\begin{array}{l}\text { Rewards and } \\
\text { punishment }\end{array}$ & & $\mathrm{X}$ & $\mathrm{X}$ & & $\begin{array}{l}\text { Not meeting } \\
\text { performance goals can } \\
\text { result in punishment } \\
\text { e.g., California's } \\
\text { contingency trigger } \\
\text { "hammer". }\end{array}$ \\
\hline $\begin{array}{l}\text { Shared } \\
\text { Governance }\end{array}$ & $\mathrm{X}$ & $\mathrm{X}$ & & & $\begin{array}{l}\text { It is slow, } \\
\text { cumbersome and time } \\
\text { consuming. Inclusive } \\
\text { at the state level by } \\
\text { law (AB1725). Concern } \\
\text { that too much } \\
\text { emphasis is placed on } \\
\text { coalition } \\
\text { representation. } \\
\text { Shared Governance } \\
\text { process varies from } \\
\text { college to college. }\end{array}$ \\
\hline $\begin{array}{l}\text { Student } \\
\text { centered } \\
\text { learning }\end{array}$ & & & & $\mathrm{X}$ & $\begin{array}{l}\text { Accountability and } \\
\text { performance emphasize } \\
\text { student outcomes. } \\
\text { Creates an emphasis } \\
\text { on learning and } \\
\text { success. }\end{array}$ \\
\hline Transitions & & & $\bar{x}$ & $\bar{X}$ & $\begin{array}{l}\text { Transitions due to } \\
\text { changes in leadership } \\
\text { and structure. }\end{array}$ \\
\hline $\begin{array}{l}\text { Workforce } \\
\text { development }\end{array}$ & & & $\mathrm{X}$ & & $\begin{array}{l}\text { Provide business and } \\
\text { industry with skilled } \\
\text { and trained } \\
\text { workforce, which then } \\
\text { effects the economic } \\
\text { development of a } \\
\text { community and state. }\end{array}$ \\
\hline
\end{tabular}

\section{California System Themes}

\section{Shared Governance}

All five of the California system participants see shared governance as a slow, tedious process whereby decisions take a significant amount of time to come to fruition. While describing shared governance, many of the 
participants spoke to the fact that it was slow because of its inclusive nature. The opportunity to participate is perceived to be one of shared governance's strengths because of the belief that it is more likely that decisions will be accepted as a result of participation. Participants were asked whether they believe there might be confusion concerning shared governance; particularly, differentiating between an opportunity to give input for decision-making versus actually making the decision. It was suggested by one executive participant that there was the potential for confusion in defining the shared governance process at the local level but did not believe that to be the case at the state level. According to this executive participant, leadership turnover at the college level tends to result in "a rough and ready quality about how shared governance is done. It may not be consistent from year to year." Whereas, at the state level because there is so much public scrutiny and the existence of the Board Standing Orders for Consultation,

Folks who participate in consultation at the state level by and large are quite sophisticated politically. They totally understand what their rights are and exactly how far they go. When a decision is made that they disagree with they won't say we didn't have a voice, they will say, you didn't accept our input. 
All five of the California system participants stated that decision-making through consensus is ideal but acknowledged that it is not required in order to move forward with any initiative. However, according to the executive participants, one flaw to the consultation process is that any group can go forward to the BOG if they are not satisfied with the recommendation coming forward.

\section{Funding}

All five of the California system participants believe that had funding not been tied to accountability measures PFE would never have been implemented by the Governor or legislators. There was consensus among all of the participants, that while the CCCS is grossly under-funded, additional revenue was not going to be forthcoming without addressing the issues of student performance outcomes.

\section{Data driven decisions}

All five California system participants agree that while some of the improvements might have happened regardless of $\mathrm{PFE}$ measurements, it was too soon to tell whether or not it was successful in improving student outcomes. Reporting results before there has been enough time from a research point of view is seen as counterproductive. A sufficient amount of time is necessary to evaluate whether or not there is a cause and effect relationship existing due to the PFE money. In addition, 
the future of PFE is in jeopardy, as illustrated by an executive participant stating, the "energy crisis has kicked the hell out of PEE." It was noted that as the California economic situation worsens it might be difficult to correlate data.

\section{Focus}

When asked what recommended changes were suggested with respect to the shared governance decision-making model for CCCS, participant responses varied. One governing participant said a "higher level of trust and constant focus on our missions." The participant also believes that strategic planning is vital in order to set priorities and receive the funds needed to operate.

This same participant commented on the significance of the Department of Finance to CCCS decision-making because of their ability to control dollars. "They get the first shot at the distribution of monies in the system and then the legislature reacts." This same participant went on to explain that recommendations from the Chancellor influenced the Department of Finance. However, the Department of Finance has the ability to disregard issues or place focus somewhere else.

\section{Leadership}

Each of the participants addressed leadership issues. One governing participant talked about the significance of 
student leadership to help understand student needs. This governing participant also commented on the fact that because of a lack of continuity in student leadership as found in the UC and CSU systems, students in CCCS have far less of an impact. When asked whether or not shared governance through consultation would continue under a new Chancellor's leadership, one executive participant responded that the structure has been captured in the Board Standing orders so it would be difficult though certainly things could change. "Rules don't control behavior. So a new leader could come and blow it off and get away with it for a while."

Two executive participants commented on the impact of the Governor's leadership particularly with respect to appointment of the BOG. According to one executive participant, BOG members could request their legislators to change the intent of AB1725. However, political fights would probably ensue. "I mean all of it is fragile as any human agreements are. New leadership comes and they just ignore policy. That is totally possible."

\section{Florida System Themes}

\section{Collaboration}

All of the Elorida system participants described the decision-making process used at the system and college 
level as collaborative and collegial. Participants identified the Presidents' Council at the system level as one of the most significant collaborative processes because it "tries to create one voice for the system." Participants believe it is vital to the future of the FLCCS for the colleges to work together, particularly with regard to its relationship with the Governor and Legislature. According to one administrative participant, "In the six years since I have been here, I have never seen an issue where we could not reach a collaborative agreement on what needs to be done on an issue." Participants see collaboration as having had a positive affect on ELCCS's relationship with the state legislators particularly because of the efforts extended to develop accountability measures that all 28 colleges could agree to for $\mathrm{PB}^{2}$ funding and reporting. The perception is that because of the system-wide collaborative efforts, community colleges are viewed as the most responsive of education systems in the state.

\section{Transitions}

The reorganization of Florida's educational governance structure was identified as a major event for the state. Participants anticipate the changes to the ELCCS as minimal as a result of the transition to a new Board of Education 
and elimination of the current state Board of Education. However, some concerns were expressed due to the uncertainty associated with a reorganization of such magnitude.

\section{Rewards and punishment}

An executive participant described reading a chart that showed "Students sitting at a desk with a 'not equal' to $\$$ next to it, students in caps and gowns with an 'equal to' \$." All of the participants agree the emphasis on student learning has had a positive impact on the system, colleges and most significantly, students. However, there is also the belief that the impact could be more significant if more dollars were tied to performance and if the point system used to drive allocation of performance dollars had more consistency so colleges could plan from year to year.

\section{Funding}

Funding on an FTE basis was described as inefficient and ineffective. One governing participant questioned what an FTE was and what relationship it had to do with public dollars invested in education. This statement was made in an accusatory tone implying that educators weren't cognizant of the value of dollars invested. On the other hand, many of the system participants were critical of the legislature's funding practices for community colleges. One 
executive participant commented about a consistent funding model that was developed internally by and for Florida's community colleges. According to this executive, the model was developed with system-wide input, consensus was reached, the model was presented to the legislators but "the legislators wouldn't embrace it."

\section{Data driven decisions}

Participants at the state level believe that data should drive decisions. However, they also believe that it takes time to evaluate data and determine the effectiveness of measurements and outcomes. Some participants view data decision making as a business model that will help governing and executive leadership to make informed decisions.

\section{Culture}

State level participants see an emphasis on performance and student outcomes to have changed the culture of the Florida Community College System. Several examples were provided throughout the interview process of how administrators, faculty and staff have been changed as a result of the statewide emphasis on production and performance. As one faculty participant observed," $\mathrm{PB}^{2}$ has had limited success because it has begun to shape the culture of institutions through the reporting requirements." According to this faculty participant, there 
isn't a faculty member in any institution that if you asked what the state's expectations were for community colleges, wouldn't answer, "enrollment, graduation rate, reduced attrition, effective and immediate remediation at the community college level."

\section{Workforce development}

State level participants see one of the biggest challenges and opportunities facing Florida's community colleges to be workforce development. One of the major concerns expressed is that performance dollars tied to workforce development are not increased dollars to the system but money that was pulled from existing budgets and pooled with K-12 workforce funds. With the implementation of the new governance structure, community colleges will compete with public schools for those workforce dollars. Another concern expressed by several participants is the fact that one of the main employment opportunities in the state is in the tourism industry, which are usually lowpaying jobs. According to this participant, the workforce development funding formula pays more for high skill, high wage job placements. The participant illustrated the point, when he commented that,

A college will earn a lot more dollars for placing somebody in an information technology program or allied health program than it will for placing somebody in the tourist industry. And one of the 
biggest needs we have in this state is in the tourism industry.

\section{West College Themes}

During analysis, it became apparent that among the seven subjects interviewed at West College, there were recurring themes in their responses. Undoubtedly some of the recurrence was a result of the specific interview questions; however, others appeared within entirely separate contexts. The following represents the most common:

\section{Shared Governance}

All seven of West College's participants were aware of and referred to $A B 1725$ and its mandated shared governance process. Shared governance is described as working fairly well at the college but the perception is that it is slow and tedious. Furthermore, executive participants describe the Consultation Council at the state level as being too representational and too faculty driven. They criticized shared governance as creating a process where individuals are more committed to representing the interests of a particular constituency group rather than the good of the college. Shared governance at the state level was similarly criticized as expressed by one executive participant, when he stated, "too much power or say is given to organizations rather than colleges." 


\section{Focus}

Another recurring theme concerned how student performance outcomes in a community college could be truly measured. There was agreement among all of West College participants that quantifying goals ignores the intangibles associated with education. A recurring question among all of the participants concerned was: How does one measure the value added to a student's personal and professional life as a result of the educational experience?

While all seven West College participants agreed that PFE has focused colleges and the system on student performance outcomes, there was also agreement educational accountability is difficult to define. When asked whether educational accountability was synonymous with improved performance, one executive participant commented that, "accountability doesn't really improve performance because you can be held accountable for bad performance."

\section{Rewards and punishment}

There was consensus among all seven West College participants that accountability in CCCS is only being addressed through PFE. There was also the perception that PEE was not universally popular at consultation and there are still many parts of it not popular and becoming less and less popular as time goes by. One executive participant attributes this to the fact that rather than 
PFE funds being free money that wasn't categorical "it has become the most categorical, non-categorical program." Additionally, executive and administrative participants spoke about the "hammer" built into PFE, which allowed for a contingency trigger should there not be system-wide progress towards the goals. Finally, there is concern that the current Governor does not support PEE as indicated by the lack of a line item in his upcoming budget.

\section{Responsibility and Authority}

Two executive participants criticized shared governance for giving too much power to faculty to influence decisions at the system and college level without any real accountability for those decisions. One faculty participant was concerned about the fact that teaching schedules limit committee participation for many faculty members. The executive and administrative participants appeared to be well versed in the shared governance decision-making process at the statewide level but not so with the faculty participants. The two faculty participants appeared to have knowledge of their college's shared governance process but limited knowledge concerning the system level process.

\section{External influences} California now has term limits for legislators and the perception among West College's participants is that the 
current Governor and legislators don't understand or care about what happened previously. All agree that, in order for any initiative to succeed, there must be a commitment in theory and resources to the mission of community colleges. There is a perception among the college participants that the current Governor "doesn't care as much about community colleges." As one executive stated, "We aren't on his radar. He puts his emphasis with K-12 and that is where he wants his money."

\section{Leadership}

All seven of West College's participants believe leadership is vital to the success of shared governance. This was illustrated by comments that emphasized the importance of having a $\mathrm{CEO}$ and board of trustees who are committed to shared governance and able to guide the institution toward actual decision-making. As one faculty participant stated, "a visionary leader is almost like a magnet" because people desperately need to see all of their committee work and involvement come to fruition.

While I think you have to have shared governance, I think you have to have a leader with vision. I don't believe everything can be accomplished in committee. There is a point at which someone has to say this is really the direction we are going to go. 


\section{East College Themes}

During analysis of the six interviews at the Florida college level, it became apparent that there were some recurring themes. Potentially, these recurrences were due to the fact that an interview guide was used for questioning all of the participants. However, some themes appeared within entirely separate contexts.

\section{Collaboration}

All six participants described East College's decision-making process as collaborative. They defined collaboration as an opportunity to give input. Participants spoke of the closed, "star chamber" model of decisionmaking used by the former president. The current style of decision-making was described as more open but still action oriented with clearly defined lines of authority.

\section{Transitions}

$$
\text { When asked to describe the decision-making process for }
$$
the system, East College participants stated that the system was about to go through a transition due to legislation overhauling Florida's entire education system. The college was also described as going through a transition phase as a result of a fairly new president and various changes to college-wide councils for decisionmaking. 
All of the participants mentioned the changes being made to the organization's structure as a result of the new leadership. Longstanding administrative councils were being eliminated and others created. Council membership was being expanded to include faculty representation. Clearly defined objectives and responsibilities were being delineated for each of the councils using a "work plan" model. According to one executive participant,

If somebody is going to work on an initiative, we want to know who is going to work on it, what the charge is, what the membership is, who the stakeholders are, what you are going to analyze, what you think you are going to implement and how you think you are going to evaluate it and a timeframe in which you expect to complete.

The intent of this work plan process is to eliminate situations where people are working on something without taking any action. "Where something is assigned to someone. Then three months later you go back to them, ask what have you done and the response is, no I didn't get around to it."

\section{Focus}

Several participants defined accountability as an assessment process. Participants felt that the best accountability measures were those that are internally created based on the needs of the community. All identified the shift to an accountability perspective as having 
improved the focus of colleges to defined goals and objectives for student outcomes.

\section{Funding}

East College participants see funding as one of the biggest obstacles facing their college. All agreed that FTE funding wasn't an appropriate way of funding colleges primarily because "FTE is driven by growth and that didn't always mean quality in the context of learning." However, East College is experiencing rapid growth without being funded for all of its growth. According to an executive participant, East College has not been adequately funded for its growth but colleges that have declining growth continue to get increases in appropriations. Another problem cited related to performance-based funding is the fact that there is no consistency in the point formula. According to an executive participant FTE funding, "is no longer high on the list of most legislators."

With regard to how the community colleges are funded, an executive participant stated that, "they need to establish a rational formula for allocating resources and stick with it." Several participants recommended that any funding formula be allowed to continue for a period of time after it is instituted--that it recognize enroliment, differences in operating costs, strategic priorities of the 
state and performance of each college. According to an executive participant, "It should be simple so that we have a business model on which to propagate for the future, because now what we have is a crap shoot."

\section{External influences} One of the prime concerns addressed concerning external influences was a tendency by legislators to get involved in issues that would be best left to the policy making boards. Participants voiced concern particularly considering that Florida voters recently elected to have legislative term limits. If legislators become "champions of specific issues like performance-based funding," the life expectancy of those issues is usually limited to the person's career in the legislature. According to one executive participant, " $\mathrm{PB}^{2}$ is a great example of that. It came from Senator Horne who has only one more year to serve in the legislature and then we will see what happens."

\section{Student centered learning}

To a person, every participant at East College talked about their Learning Centered Initiative and its impact on the organization. This focus has permeated throughout the institution according to all of the participants. A recurring message was that while East College had experienced a paradigm shift before hiring their current president, they see him as someone who can move them 
forward with regard to student centered learning. Additionally, one executive participant said that, "We who are interested in learning feel better about the state governance now that we are looking at performance as opposed to FTE." This participant believes that if an organization is really interested in student learning it has to look at outcomes. According to this participant, "Performance is something we can acknowledge and we can make certain in-house decisions based upon quality rather than the number of seats we are filling."

\section{Leadership}

All of the college participants identified leadership as vital to any organization. The leadership styles of the current president and predecessor were described as diametrically opposed. The predecessor was described as autocratic, "holding decisions close to his vest" and operating using a "star chamber" model where only select individuals were involved in decision-making process. The current president is seen as more open and collaborative. The faculty participants were obviously excited and optimistic about this president who they described as have an "entirely different leadership style" from the predecessor. However, one faculty participant stressed that the organization had to be patient as the 
transformation due to the different leadership style was "awkward for some" and would require a great deal of work on the part of everyone. According to this faculty participant,

An institution is like a cruise liner. It doesn't turn around on a dime. You have got to move it around and so we just have to be patient, which is hard. It is hard because every time you see something that appears to be kind of a fallback on the old way of doing things immediately the defenses go up. Oh my God, what happened?

An executive participant expressed similar enthusiasm about East College under the leadership of this new president stating, "We have been really blessed with Dr. Y."

\section{Summary}

The purpose of this study was to explore the relationship between decision-making processes used in a community college system at the statewide and local district level to examine what impact the process has on attempts to address accountability tied to student performance outcomes. Specific areas of concern included shared governance and other participatory decision-making models, defining and measuring student success, and funding issues particularly based upon attainment of student performance outcomes. 
The interviews and review of documents provided addressed these concerns and were presented in this chapter. Triangulation as a method of understanding the issues was used in this study. This was accomplished primarily through examination of the data at the state (system) and local (college) level. Data were analyzed using exploratory, descriptive and explanatory procedures. Composite profiles of both states were presented in Table 2 and of both colleges in Table 3 in an attempt to report findings related to the current economic and demographic climate of each community college system. The findings were presented according to the four research questions. The data were then grouped into recurring themes at the system and college level and presented in Table 4 as well as in narrative summary for each state. Major conclusions related to the research questions in this study are summarized as follows:

1. Whether by mandate or by convention, participatory decision-making results in a higher degree of commitment by all constituencies at the college and system level. When there is an opportunity for input prior to the final decision, people are more likely to support an initiative. Speaking with "one voice" as a system will actually enable a community college system to command the 
attention of the Governor and the Legislature, particularly with respect to funding as it competes with other state agency demands .

2. An emphasis on accountability that is identified as student learning and success focuses a college and system on achieving those. Administrative barriers are removed, which allows students to complete course work in a timely manner, thus enabling them to pursue transfer or employment opportunities while efficiently using taxpayer resources. Using a business model of inputs and outputs does not negate or minimize the importance of the intangibles associated with an educational experience.

3. Leadership is key to the success of any initiative. Leadership at the state, system and college level that is open, inclusive, responsive and action oriented increases the effectiveness of an organization or institution.

4. The greatest disappointment experienced by nearly all who participated in this study is that community colleges have been and continue to be under-funded. The cost to a state is significantly less than any other public or private education system, yet the resources provided are minimal in comparison. Funding formulas must be developed 
that adequately provide resources for community college education.

5. Performance funding provides additional resources to community colleges while demonstrating a return on taxpayers' investment. However, in order for results to be meaningful, a sufficient amount of time must be allowed for data collection and evaluation along with a consistent and significant source of funding for the performance incentive piece. Data driven decisions encourage and reward planning. 6. Community colleges should not be hampered by external influences related to political or personal agendas, term limits, or political affiliations of legislators or Governors. Consistency in initiatives allows colleges to engage in long-term planning, which one trusts will result in informed decision-making on the part of elected officials.

7. Community colleges provide an opportunity for economic development for the communities and states served. During these times of decreasing state resources, increasing and diverse populations, community colleges provide a trained workforce in an efficient and cost effective manner. 
Discussion, implications and recommendations for

future study as a result of these findings are presented in Chapter 5 . 


\section{CHAPTER 5: DISCUSSION, IMPLICATIONS AND RECOMMENDATIONS}

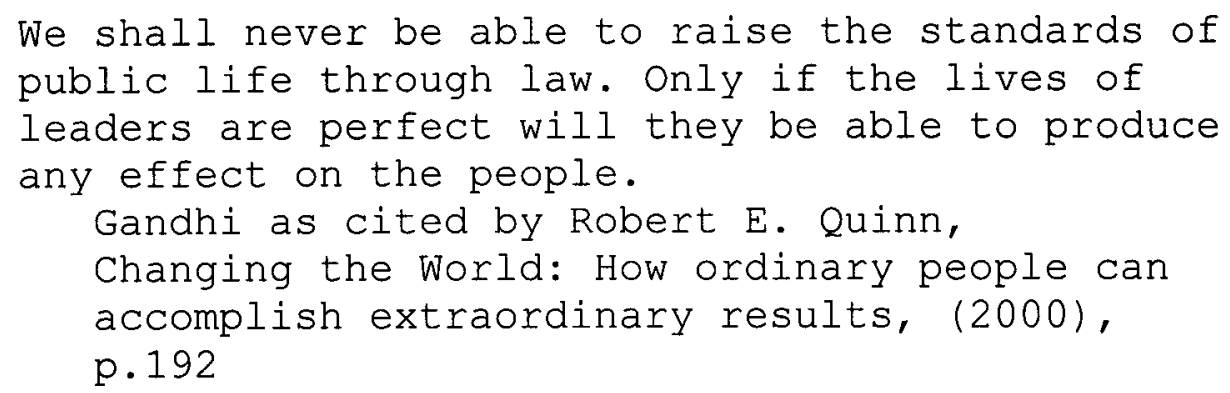

\section{Introduction}

As soon as one reads the word perfect in the above quote, Gandhi's statement might be disregarded. Clearly, Gandhi was not speaking of perfection as a state of being without flaws but rather as a state to be aspired to. This study was not initially intended to be an examination of leadership. However, when examining the relationship between shared decision-making and accountability tied to student performance outcomes, it became obvious from the data that leadership is key to the success of any initiative.

One of the objectives for this study was to determine how governance, whether shared by legislative mandate or by convention, affects efforts to address accountability through student performance outcomes tied to performance funding. Another objective was to determine whether or not 
the decision-making process used impeded or advanced such efforts. This chapter discusses and draws conclusions regarding the findings in the context of the four research questions. Implications of the findings are identified and the researcher's recommendations for further work along with a discussion of the limitations of the study conclude the chapter.

\section{Summary of the study}

Community colleges serve all segments of society by placing higher education within reach of virtually all who seek it. The needs and desired outcomes of students are as varied as the diverse populations of students attending the nation's community colleges. Economic conditions have forced elected officials to examine how a state's resources are being used to ensure that the public return on investment meets or exceeds expectations. However, there appears to be some concern that an emphasis on accountability in the form of inputs and outputs is diametrically opposed to the academic philosophy of education.

According to Leon Marzillier, a California statewide faculty representative in an article responding to recent changes by the Accrediting Commission for Community and Junior Colleges (2002), "This requirement, that there be 
continuous improvement of learning outcomes, assumes that student achievement can be increasingly rationalized like a production process." (Senate Rostrum, October 2002). Such comments as this and according to additional findings reported in Chapter 4, it might appear that educators are concerned with the increasing emphasis on student performance outcomes based upon a business model of inputs and outputs.

Additionally, inherent to college governance in many community colleges throughout the nation is the expectation that a collegial or participatory model of decision-making is the appropriate mode of governance for the academy. This type of model structures an organization so that it allows the opportunity for all constituencies to participate in decision-making. Some states, such as California, have mandated a participatory decision-making process, commonly referred to as "shared governance" (AB1725, 1988), while others operate in a similar manner not by legislative mandate but rather by commitment to the collegial spirit of the academy.

States, such as Florida, which attempts to make decisions collaboratively have also legislated structural governance (SB1162, 2001) in an attempt to create a "seamless" educational system to improve accountability for 
the use of state resources. In fact, according to the findings reported, Florida is unique in that no other state has implemented a truly integrated $\mathrm{K}-20$ education governance structure.

Both California and Florida passed initiatives tying funding to specific student performance outcomes. California's Partnership for Excellence (PFE) program was developed through the consultation process mandated in AB1725 (1988). In contrast, Florida's Performance-based Budgeting $\left(\mathrm{PB}^{2}\right)$ program was legislated for all government agencies with community colleges being the first of Florida's education institutions to be required to participate. However, according to the findings reported in Chapter 4, both systems internally developed the accountability measures to be used in funding performance for community colleges.

The case study approach allowed for an in-depth examination and analysis of the issues that arose as both of the community college systems and colleges responded to increasing demands for educational accountability. The study explored themes in the participants' perceptions of shared decision-making, and performance funding tied to student outcomes as a measure of accountability. The findings described legislation, perceptions, attitudes, 
structures and processes and other concerns related to governance and accountability for community colleges in each state.

This chapter provides discussion and implications of the findings within the theoretical framework of the four major research questions. Additionally, the following subresearch question is inherent in each of the above questions: How, if at all, do these perceptions differ at the state (system) level from the local (college) level.

\section{Discussion}

\section{Research Question One}

What is the governance or decision-making process used for community colleges in each state as described by key stakeholders?

Consultation as mandated by AB1725 requires the Chancellor and his staff to involve all system-wide constituencies in decisions that affect the California Community College System as an organization. A key benefit to this process appears to be the inclusiveness of decision-making with the outcome being that recommendations brought to the Board of Governors will be more likely to be accepted and supported. Consensus is not required though every effort is made to reach consensus before moving initiatives forward to the BOG. A benefit identified is 
that by working through the Consultation Council, the system appears to be speaking with one voice and the legislators are more likely to accept the recommendations and not attempt to micromanage the organization. In addition, because consultation allows for broad constituency representation, the perception is that decisions will be more likely to be accepted and institutionalized throughout the system.

However, the consultation process can be slow, taking as much as two to three months to move something through consultation. And because the Consultation Council consists of broad constituency representation, it can be dysfunctional at times. This dysfunctional behavior is attributed to the fact that decision-making can become more of a coalition decision-making process with each constituency group advocating representational positions rather than institutional positions. Another issue concerns the actual term "shared governance," because the concept is mandated in the consultation language but the term while commonly used throughout the system is not specifically identified in the mandate. This lack of definition results in different interpretations throughout the system, which can disrupt the decision-making process particularly at the college level. AB1725 mandated the 
concept of consultation; however, it did not mandate the actual process to be used at individual colleges. Similarly, the shared governance process is subject to conflicting definitions and understandings that varies from college to college and potentially, creates unrealized expectations regarding decision-making.

Florida does not have such a mandate but it does attempt to address issues collaboratively statewide, particularly through the Council of Presidents. In contrast to California's constituency representation, Florida has college representation with regard to decision-making through its Council of Presidents. The perception is that by reaching agreement among the presidents and colleges before bringing an initiative forward, the legislators are more likely to view the community colleges as a system speaking with one voice rather than as competing entities and therefore, respond more favorably to requests. Likewise, consensus is aspired to but certainly not a requirement as presidents can work around the process and approach a legislator directly. However, the perception is that the new crop of presidents into the Florida community college system appear to be more inclined to use a participatory or collaborative system of decision-making for the system and at their individual college than past 
college presidents. However, as with California, because collaborative decision-making processes are defined and structured by the college's leadership, it too can vary from college to college.

Both states appear to use a collaborative input process for decision making at the state level, the key difference being that California's Consultation Council includes all system constituency representation while Florida's process includes only college presidents through the Council of Presidents. The implication of this difference is that Florida's process of including only the presidents may be easier, yes. Better, not necessarily as there are fewer perspectives considered in arriving at decisions that will affect all constituency. How many voices have to be heard before we can say that decisionmaking is a collaborative or shared process?

\section{Research Question Two}

What effect, if any, did the governance process have on the development of the accountability measures and performance-based funding initiatives currently in existence (PFE in California and $P B^{2}$ in Florida) as perceived by key stakeholders?

In addition to defining a decision-making process for the CCCS, AB1725 required the system to begin to address educational accountability. Among other things, the bill 
authorized the Chancellor, pursuant to consultation, to adopt student assessment measures. It also directed districts to:

Identify, review, and record certain information, and to maintain specified programs related to matriculation and availability of courses and services, including those which meet the diversity of student and community needs. (AB1725, 1987, (24) p.11)

The legislation directed the Chancellor to assess and initiate a renewed emphasis on student retention, transfer, completion of vocational education programs, and skill level improvement. In 1990, the Board of Governors adopted the AB1725 Model Accountability System. This model defined accountability as the "use of information to measure progress in the attainment of specified goals" (AB1725 Accountability Task Force, 1990, p. 2). The five educational reform goals delineated in the AB1725 Accountability Model dealt with student access, student success, student satisfaction, staff composition, and fiscal condition. However, it was nearly a decade later before the CCCS developed system-wide goals, which tied funding at the state level to accountability of student performance outcomes in its Partnership for Excellence (PEE) program. 
The accountability measures used in PFE identified as student performance outcomes were developed through the mandated consultation process. As a result there was general agreement that all could "live with" the measures delineated in PFE. Since the PFE program was established in 1998-99, it has produced impressive results. According to a presentation given by the Chancellor to a Senate subcommittee in March 2003: UC transfers have increased 21\% and CSU transfers have increased by $12.2 \%$. The number of associate degrees and occupational certificates has also increased by $11 \%$. The rate of successful course completion has increased slightly to its current rate of $69.3 \%$ and workforce development course completions have increased by $30 \%$ (Nussbaum, p. 6). According to a study reported in Community College Week (June 2002), California community colleges represented twenty-three of the top 100 Associate degree producers for 2000-01 (The Top Associate Degree Producers, p. 6-7). Furthermore, California serves a diverse population with an expected growth rate of $16 \%$ by the year 2020 anticipated for the state (Table 2). This statewide population growth will undoubtedly result in an increase to the 2.9 million students currently served by CCCS . 
In the Florida Community College system (ELCCS), several factors in the $1900^{\prime} \mathrm{s}$ resulted in Florida addressing issues of performance-based budgeting and funding tied to student outcomes, planning, internal and external accountability, and its current governance structure. FLCCS was the first sector of higher education in Florida to face the challenge of performance-based funding. According to The Florida Community College System: A Strategic Plan for the Millennium 1998-2003 by the Florida State Board of Community Colleges (January, 1999),

While measures had been previously developed in response to a 1991 accountability requirement, the tie between funding and performance did not occur until 1994. The Performance-based Budgeting $\left(\mathrm{PB}^{2}\right)$ process was seen as a way of focusing government on results with incentives that would be available to hold agencies accountable. ( $p$. 49)

In the introduction to this strategic plan report, the purpose for developing the plan was,

To provide a framework for informed decision making for the twenty-eight institutions in the Florida Community College system while providing feedback to the public and legislators. Three major areas-Access, Outcome and Funding-were selected initially as the focus of the plan ( $p$. $5)$.

A task force consisting of four Community college Board members, three presidents, three vice presidents and 
one campus provost was convened to develop the statewide strategic plan. The task force held a total of seven meetings throughout the state, each of which included reserved time for public testimony. These meetings were held to gather information for purposes of developing the long-range strategic plan for the FLCCS. It had been determined that a plan had to be developed if the Florida community colleges were to meet the challenges facing the state in the years to come. According to the strategic plan report, "by the year 2000, Florida is expected to rank third in the country in terms of total population." In addition, the ethnic composition was expected to change significantly with the state's population becoming more diverse with a significant increase in the Hispanic population. The population aged 18 and over was also projected to grow by a million with the anticipation that by $2010,54.4 \%$ of the youth population will be non-white. (Strategic Plan for the Millennium, January 1999, p. 12). The impact of the above population changes along with a growing demand from business and industry for a trained and skilled workforce to meet the economic growth patterns projected for Florida over the next 10 years required the FLCCS to examine and plan for the future. 
In 1994, the legislators had enacted the Government Performance and Accountability Act to establish performance-based budgeting throughout all state agencies. As previously stated, the ELCCS was the first education agency in the state to begin operating under the $\mathrm{PB}^{2}$ or $\mathrm{PBB}$ process which required that funding and performance be tied together. According to the FLCCS: Strategic Plan for the Millennium Report 1998-2003 (January, 1999), "the PBB measures have focused on awards and the students who receive them" (p. 49). The amount of increased funds to the FLCCS has been relatively small; however, it does appear as if the process has resulted in improved performance for the system. According to a study reported in Community College Week (June, 2002), 7 of the top 10 Associate degree producers for 2000-01 were Florida community colleges with Florida having twenty-six of the total one hundred schools reported (The 100 Top Associate Degree Producers, p. 6-7). The effect of the decision-making process in each state has resulted in both state systems receiving performance-based funding tied to student performance outcomes. The CCCS self-imposed performance-based funding program tied to accountability measures in an effort to obtain additional revenues for the system. In contrast, Florida's legislators mandated performance-based funding 
tied to student performance outcomes funding for FLCCS. However, both community college systems internally developed the accountability measures used to fund the colleges based upon student performance outcomes.

\section{Research Question Three}

What differences, if any, exist within each state's governance process to indicate any possible impact on how each state is addressing accountability and performancebased funding?

The accountability measures used in $\mathrm{PFE}$ and $\mathrm{PB}^{2}$ (PBB) were similarly created in that each system internally developed the accountability measures to be used to fund the community college systems based upon performance. However, as previously discussed with regard to research question two, one of the primary differences between the two state's performance-based funding models is related to how each of the performance-funding programs came to exist. California's PEE was an internal initiative in an attempt to increase funding to the CCCS. While $\mathrm{PB}^{2}$ was an external initiative legislated for all government agencies and did not result in any additional funding to the FLCCS though it did result in increased funding to particular colleges as a result of attainment of performance outcome measures.

$$
\text { California's PFE program increases total system }
$$

funding, which is then distributed throughout the system on 
an FTE (full-time equivalent) student basis. Colleges and districts report measurement results regularly to the Chancellor's office. However, individual colleges are not currently held accountable for meeting those goals and funding is received regardless of outcomes through the FTE funding formulas. On the other hand, Florida's $\mathrm{PB}^{2}$ program funds individual colleges based upon attainment of the accountability measures. Performance-based funding in both states is minimal. The primary difference between the two states is that Florida's performance-based funding only funds a college for performance if it achieves its accountability goals. In contrast, California funds all colleges regardless of attainment of specific accountability goals. The implication of this difference is that because Florida is holding each individual college accountable for student performance, the Florida colleges might be more likely to focus more efforts on achieving student outcomes.

\section{Research Questions Four}

How has the state's governance process impeded or advanced the formation and implementation of the performance-based funding process ( $P F E$ in California and $P B^{2}$ in Florida) as perceived by key stakeholders?

The perception is that while the actual concept of performance funding was not similarly initiated, both 
states allowed for input into the actual accountability measures. Due to the reporting requirements of both states regarding achievement of the accountability measures, there appears to be an increased focus on student outcomes. Data are being used to drive decisions and there is a greater emphasis on strategic planning. The biggest impediment is seen to be the lack of significant funding to the systems to accomplish the goals and objectives defined for community colleges. Also, it takes time to establish trends and analyze data so each of the programs must be given the opportunity to succeed and impact educational accountability.

Furthermore, this study found that performance could not be strictly based upon an outputs model, as there are many other variables to be considered when evaluating educational success. A business model of inputs and outputs assumes some control over inputs and sufficient resources throughout the production process to achieve specific quality outcomes. Community Colleges serve all segments of society through open-access admissions while providing comprehensive and community based educational programs that foster lifelong learning. The mission and scope of community colleges is far reaching so therefore inputs cannot be quality controlled the way they are in a business 
model. To attempt to do so would be in direct conflict with the stated mission of community colleges. Access does not mean that community colleges are without standards, but it does mean that programs must be provided for students to obtain the necessary prerequisites for entry. Adequate funding is imperative if community colleges are to provide programs that ensure such quality inputs. Finally, can an output model based totally upon quantitative data measure educational accountability? Education of a student consists of many intangibles including the development of social skills, critical thinking, and application of learning, and responsible citizenship, all of which are more qualitative in nature. The implications of measuring outputs purely based upon quantitative data are that qualitative measurements that reflect a student's ability to think, learn, value, and process information are ignored.

\section{Related Conclusions and Discussion}

It is intriguing to find that conclusions arose during analysis that were not central to the initial research questions but appear to be particularly relevant to any discussion related to issues of governance, accountability, performance and funding. They include findings related to

1) the economy; 2) workforce development; 3), other 
educational systems; 4) student centered learning; and, 5) leadership.

\section{The Economy}

Unfortunately, California's multi-billion dollar deficit along with a slowed economy has resulted in proposed cuts to various community college programs, which potentially might amount to $\$ 530$ million or a $10.5 \%$ reduction in the 2002-03 community college budgets with a similar reduction in 2003-04. The budget proposal also includes the most significant fee increase from $\$ 11$ per unit to $\$ 24$ per unit in 2003-04. However, the increase in fees would not provide additional revenues to the colleges. Net revenues from the fee increase would go directly to the state's General fund and not be available for the colleges' use. (California Community College Chancellor's website, News Releases, January 10, 2003, p.2). Several essential programs geared towards student success, including $\mathrm{PFE}$, are at risk with reduced funding expected and in some cases, programs discontinued. (Chancellor's office News Release, January 10, 2003, p. 1)

In contrast, according to Governor Bush's budget recommendations for fiscal year 2003-2004, Florida is "much better off than most of the nation" but it also acknowledges a tough budget year ahead. The community 
college system's 2002-03 operating fund received an increase of $8.7 \%$ over previous year's appropriation. And the 2003-04 budget proposed by the Governor includes a $1.8 \%$ increase over the current year. In addition, the Governor's proposal includes a $7 \%$ increase in student tuition, which would be directed to the colleges. However, due to recent voter approval of Amendment 9, a high-speed rail initiative, the FLCCS will not receive additional funds to cover increases in student enrollment. (Board of Education Media Advisory, January 21, 2003, p. 3)

\section{Workforce Development}

While the economy has slowed down nationally, it is anticipated that the demand for high-skilled, technologically savvy workers will continue to increase particularly when the economy begins its inevitable upswing. Many decision makers would argue that community colleges have an opportunity to position themselves for this upswing by developing programs that are geared towards the demands of industry.

Both California and Florida have begun to address workforce development in their states. Initially Florida's $\mathrm{PBB}$ included $\mathrm{AA}$ (Associate of Arts) degrees and workforce development outcomes in PBB accountability measures. However, among other things, SB1688 (1997) split the 
workforce away from the process; it funds workforce improvements separately so that $\mathrm{PBB}$ is currently limited to AA degrees and College Preparatory outcomes.

During the 1997 and 1998 legislative sessions, workforce development funding based on performance became one of the higher priority pieces of legislation for both chambers. The result, which is still to be implemented, is a funding system that merges funding for adult education, vocational credit education, and degree/college credit education into one system. Both school districts and colleges will earn funds from this system, and will have 15\% of their prior year funding "at risk" based on their performance. (The Florida Community College System: A Strategic Plan for the Millennium 1998-2003, January 1999, p. 53)

Clearly, community colleges must take the initiative and anticipate the demands of the future in developing programs and courses. The American economy continues to be transformed by technology and the entrepreneurial spirit. In order for companies to compete globally through innovation, increased and competitive production, a skilled workforce is needed. Florida and California leaders have recognized this and are attempting to fund community 
colleges based upon achievements in workforce development goals.

\section{Other educational systems}

Community Colleges compete with other educational

systems for limited resources in each state. As one California participant stated, "the people who are the most effective at creating student learning are the least funded." The perception is that as long as funding is based upon prestige and alumni association of legislators and other leaders, community colleges will continue to be under-funded. Community colleges are much more cost effective regarding student learning and outcomes yet an inverted pyramid appears to exist between funding and outcomes. State colleges and universities receive more funds in both states, particularly so with each of the university systems. Yet, it is the community colleges that serve the most students. As states continue to experience massive population growth and diversity of that population, more and more demands will be placed on the community colleges.

\section{Student centered learning culture}

An increased focus on accountability measures and performance appears to have resulted in a shift in education especially in developing student support services that are more student-centered. This was strikingly 
apparent in the Florida findings both at the system and college level. In addition, students are being asked to demonstrate critical thinking and communication abilities beyond the discipline specific competencies. The Florida College President has created a collaborative planning environment that invites input where the focal point of every decision, every dollar spent is on "how will this affect student learning and how will we know it affected student learning." Colleges are looking at ways to remove administrative barriers to students' achieving their goals. However, clearly it is important to recognize that an education system that only emphasizes outcomes and quantitative goals ignores the intangibles of education that are so important to lifetime achievement.

\section{Structure versus Leadership}

The most significant finding of this study is the confirmation that leadership is key to the success of any initiative. Structure may be mandated but it is merely that, a structure. People will work within structure but perhaps without real commitment being fostered. It is not the structure that moves an organization forward but the individuals leading the organization. A Florida college faculty participant demonstrated this when discussing the new structure developed by the current president for 
decision-making as, "fundamentally changing" the organization and the culture. The impact of the president's leadership style was further evidenced by an executive participant at the Florida college when comparing the previous and current president's student centered leadership styles, "Dr. X (previous president) didn't get in the way of the learning initiative but he also didn't really experience, live or understand it the way Dr. Y (current president) does." So, when we talk about student outcomes and pedagogical issues, we don't have to decipher for him, "Its almost like we have to pinch ourselves every once in awhile. It is like there was a cloud holding us back from real break through" regarding student outcomes. However, community college leadership encompasses more than the presidents to include, the Legislators, Governor, and Governing boards. All of these individuals have the authority and power to make decisions but it is only with true collaboration that decision outcomes are fostered, nurtured and attained. The most salient finding demonstrating leadership at this level is that Florida and California have approached the issues of accountability and governance in the reverse but clearly, the intent is the same. California's leadership first addressed governance in 1988 through AB1725, establishing a system-wide process 
for decision making, which directed future development of accountability with regard to performance. Florida on the other hand, first enacted performance funding tied to accountability and has recently begun to address its entire educational governance process. Both states have dealt with issues of accountability, performance-based funding tied to student performance outcomes and decision-making governance; however, in a different order and manner. Clearly, it is the leaders of each state, system, and college who will determine whether or not true success has been attained. To paraphrase Gandhi's eloquently stated quote at the beginning of this chapter, law does not raise standards, leaders do. The implication of this difference is that California's shared governance process is commonly described as dysfunctional because individuals have a tendency to represent their personal interests and those of their constituency rather than the good of the system. On the other hand, Florida's process of including only the presidents may be easier; however, it may not necessarily be better. Can decision-making be described as collaborative that limits the number of voices heard? Additionally, the lack of inclusiveness of broad constituency representation will probably result in limited systemic change. 


\section{Implications for Leaders and Policymakers}

The implications of shared decision-making on accountability efforts tied to student performance outcomes are more complex than they first appear. Based upon the data collected, analyzed, reported and discussed in this chapter, the following are some implications identified for leaders and policymakers as a result of this case study.

- In a participatory or shared decision-making process, efforts at accountability may be limited by a tendency of individuals to protect personal or constituency interest rather than identifying performance outcomes that truly impact or measure student success.

- Accountability initiatives that measure and report student outputs without considering accountability for inputs will not result in true educational accountability that will make significant improvements in student outcomes.

- Leaders and policymakers considering mandating or using participatory or shared decision-making to govern may wish to explicitly define the terms, processes and conditions. While more prescriptive and perhaps less collegial in nature, the clarity will minimize confusion and varying interpretations thus allowing for more consistency in how decisions are reached. 
- Without consistent and adequate funding and time for data reporting and analysis, systemic change is not possible.

- Accountability as defined by most is having individuals who can read, write and think independently. The number of degrees awarded is a false measurement if the degree does not produce competent contributing members of society.

- Meaningful educational reform must also address underlying societal problems. Education is under constant scrutiny to try and meet unreasonable demands from the public many of whom have abrogated their personal responsibility to be educated. In general, a lack of or insufficient accountability efforts may not be the problem with education -- values and expectations may be the issue. Educational reform with quick fixes of measuring quantifiable data while ignoring qualitative outcomes does not address underlying social concerns and will continue to result in a general lack of confidence in $\mathrm{K}-20$ public education.

\section{Recommendations for Further study}

Ultimately, it may be concluded from this study that if college and system constituencies are to share in decision-making processes, it is imperative that the 
leadership style of the college president and the system chancellor be one that fosters and nurtures such collaboration. There is a wealth of diverse leadership ability within community colleges and those that will enter the field in the years to come. As education continues to move forward using a business model of performance to justify funding, leaders are needed who can rise to the challenge of adapting system and institutional culture to respond to these demands while ensuring that the emphasis on performance does not mitigate the quality of academic excellence or attainment of the mission of community colleges. Thus, examining community college leadership would result in community college organizations that provide increasing and diverse state populations with an educated and skilled citizenry in an efficient and cost effective manner.

Several recommendations for further research can be made as a result of this study. One such study might be to examine whether California's AB1725 created expectations of shared decision-making that has resulted in an environment of coalition representation rather than collective representation. Another is a quantitative study including a large number of stakeholders from both states to compare perceptions concerning the impact of shared or 
collaborative decision-making on efforts related to accountability tied to student performance outcomes. Another is replication of this case study using other colleges within each system and also other community college systems similarly addressing issues of decisionmaking governance and educational accountability measured by student performance outcomes. Quantitative or qualitative studies of other states introducing accountability and performance-based funding systems are also recommended for further research. Such studies might also include whether or not the increase in student performance outcomes has affected the state's economy through workforce development. In addition, longitudinal evaluation studies of outcomes to determine the impact of each state's decision-making process on accountability outcomes .

Finally, further examination of the two colleges included in this study to analyze the effectiveness of the president's leadership at both or one of the colleges, particularly regarding shared decision-making and external demands for accountability should be made. Such an examination of the leadership of one or both of the current presidents could provide some important insights and a model for effectively selecting a president for an 
organization seeking to incorporate shared or participatory decision-making into that organization's structure.

\section{Iimitations of the Study}

This study utilized a purposeful sampling technique to address the research questions. California and Florida were selected because each possesses unique or extreme aspects with regard to governance and issues of accountability as it relates to student performance outcomes. Therefore, this study will only be transferable to community college systems similarly addressing issues of governance as it relates to decision-making and accountability as measured by student performance outcomes.

California appears to be unique in that it mandated its statewide decision-making process, commonly referred to as "shared governance" in AB1725. The state of Florida does not have such a statewide decision-making process but it was in the midst of restructuring its entire educational governance structure, which was effective January 2003 after most of the data had been collected and analyzed for this study.

In addition, only one college from each system was selected for inclusion. Therefore, the findings created some insights into the two state systems but certainly cannot speak for the whole community college system within 
each state. The two colleges selected were also in a great deal of transition. The California college's president had recently resigned after more than a decade of service. An interim president was in leadership during the time of data collection. Simultaneously, the California college faculty voted for unionization and they were in the process of transitioning to this new representational process. Therefore, assessment of the results of such a change was not considered in the findings or what such union representation's impact will be on the shared decisionmaking process at that college. The Florida college's president, hired one year prior to data collection, was in the process of restructuring the entire college's committee representation. The final structure and its impact on the college's decision-making process were not considered in the findings. Therefore, the findings may be reflective of the flux each college was experiencing due to system and college-wide transitions. 


\section{References}

Accrediting Commission for Community and Junior Colleges. (ACCJC). [Announcement posted on World Wide Web]. Retrieved October 30, 2000 from the World Wide Web: http://www.accjc.org.

Baca, J. M. (1998). A history of California community college governance and trustees' perceptions of the faculty role in district and college (shared) governance.

Unpublished doctoral dissertation, University of Southern California, California.

Bogue, E. G., \& Aper, J. (2000). Exploring the heritage of American higher education. Phoenix, Az.: The American Council on Education and The Oryx Press. 83-107, $212-216$

Borden, V.M.H., (2002, June 24). The Top 100 Associate's Degree Producers. Community College Week, p. 612)

Borden, V.M.H., (2002, June 24). Onward \& Upward: Trends and Analysis in Associate's Degree Conferrals. Community College Week, p. 8 .

Bush, T. (1995). Theories of educational management $\underline{\left(2^{\text {nd }} \text { ed. }\right)}$. London: Paul Chapman Publishing.

California Citizens Commission on Higher Education. (1997). Through the looking glass: The California Community 
Colleges as seen through AB1725. A roundtable discussion sponsored by the California Citizens Commission on Higher Education.

California Code of Regulations: Title 5, Section 53200-52304. (1990) State of California, Sacramento. California Community Colleges AB1725 Accountability Task Force. (1990, July). AB1725 Accountability System. California Community Colleges. Sacramento, Ca. (ERIC Document Reproduction Services No. 319461). California Community College Trustees (CCCT) . (1989) . Implementing the shared governance provisions of AB1725: trustees and CEO responsibilities. Prepared by Janis Cox Jones, Consultant, Educational Policy Analysis. December 1989.

California Community Colleges Chancellor's Office. (1999). The fact book: Partnership for Excellence district and college baseline data for 1995-96, 1996-97 and 1997-98. Sacramento, CA.

California Community Colleges Chancellor's Office. (1999). Partnership for Excellence: Frequently Asked Questions (FAQs). [Announcement posted on the World Wide Web]. Retrieved July 31, 2000 from the World Wide Web: http://www. cccco.edu/partnreship.html. 
California state [Announcement posted on the World Wide Web]. Retrieved November 8, 2000 from the World Wide Web: http://www.state.ca.us/education.html.

California State Legislature. (1988). Assembly Bill

1725: Community College Reform Act (Vasconcellos, et al.). Sacramento: State of California.

Campbell, D.F. (2000). Critical Issues Facing

Community Colleges. Institute of Higher Education:

University of Florida

China, J.W. (1998). Legislative Quality: Boards that

Make a Difference. San Francisco: Jossey-Bass.

Covey, S. (1991). Principled-centered leadership. San

Francisco: Jossey-Bass.

Deas, E. (1998). Shared governance in the British

Columbia post-secondary education system: The board's role

in decision-making. Unpublished doctoral dissertation,

University of San Diego, California.

Flanigan, P. K. (1994). California Community Colleges

faculty role in shared governance. (ERIC Document

Reproduction Services No. 373 816).

Florida State Bill 1162 (SB1162), (2001). Florida

Legislature. Chapter No. 2001-170.

Florida Community College System, Office of

Educational Effectiveness and Research. (2000, July). 
Accountability in the Year 2000. Retrieved July 22, 2000 from the World Wide Web:

http://www.dcc.firn.edu/dccrepts/oeer/dt15.html.

Florida State Board of Community Colleges. (1999, January). Community College System: A Strategic Plan for the Millennium 1998-2003.

Florida State [Announcement posted on the World Wide Web]. Retrieved November 8, 2000 from the World Wide Web: http://www.state.fl.us/education.html.

Florida State Legislature, Tallahassee. Office of Program Policy Analysis and Government Accountability (OPPAGA). (1998). Review of the community college system's Performance-Based Program Budgeting measures and incentive fund. Report 97-49. (ERIC Document Reproduction Services No. 425778$)$.

Francis, C.A. (1990). Profiles in faculty leadership: the experience of 1985-86 California Community College senate presidents. Unpublished doctoral dissertation, University of San Diego, California.

Gibson, J. L., Ivancevich, J. M., \& Donnelly, Jr. J. H. (1985). Organizations: Behavior, structure, processes. $\left(5^{\text {th }}\right.$ ed.). Texas: Business Publications.

Giese, R. J. (1996). Assessing the organizational cultures of the California Community colleges that have and 
have not implemented shared governance. Unpublished doctoral dissertation, University of La Verne, California Glesne, C. (1999).

Glesne, C. (1999). Becoming qualitative researchers:

an introduction. ( $2^{\text {nd }}$ ed.) . New York: Addison Wesley

Longman.

Goodwin, G., \& Young, J. C. (1978, July). Increase productivity in the community college. Topical Paper number 67. League for Innovation in the Community College and ERIC Clearinghouse for Junior Colleges. University of California, Los Angeles.

Guba, E. G., \& Lincoln, Y. S. (1981). Effective evaluation. San Francisco, Ca.: Jossey-Bass.

Hatfield, S.R., \& Gorman, K.L. (2000). Assessment in Education - The Past, Present, and Future. Reston, VA.: National Business Education Association.

Honeyman, D. S., Wattenbarger, J. L., \& Westbrook, K. C. (1996). A struggle to survive: Funding higher education in the next century. Thousand Oaks, Ca.: Corwin Press.

Howell, C. S. (1997, October/November). An Assessment of the Implementation of Shared Governance Provisions of AB1725 (1988) at Selected California Community Colleges. Community College Journal of Research \& Practice, 21, 7-13. Jensen, R., Giles, R., \& Kirklin, P. (2000). Insider's 
guide to community college administration. Washington, D.C.: American Association of Community Colleges.

League for Innovation [Announcement posted on the World Wide Web]. Retrieved November 8, 2000 from the World Wide Web: http://www.league.org/projects.html.

Little Hoover Commission. (2000, March). Open doors and open minds: Improving access and quality in California's Community Colleges. (Report \#154). Sacramento, Ca: Author.

Manzo, K.K., (2002, February 18). A Community College Life: An interview with Dr. George Baker. Community College Week, p. 6-8.

Marzillier, L.F., 2002, October). The Accountability Game. Senate Rostrum: Academic Senate for California Community Colleges Newsletter, p.14-16.

Merriam, S. B. (1988). Case study research in education: A qualitative approach. San Francisco, Ca.: Jossey-Bass.

Meyerson, J. W. (1998). New thinking on higher education: Creating a context for change. Bolton, MA: Anker Publishing Company.

Miller, M.T. (1999). Responsive Academic Decision Making: Involving Faculty in Higher Education Governance. Stillwater, Oklahoma: New Forums Press Inc. 
Moak, M. M. (2000, March). A view from the states: A survey of the collection and use of cost data by states. A compilation of background papers prepared for a seminar on cost management, The Institute for Higher Education Policy, TIAA-CREF Institute 10-27.

Mortimer, K. P. (1972). Accountability in higher education. San Francisco, Ca.: Jossey-Bass.

Moskus, J. (1999, April). Soaring moles and burrowing eagles: Decision-making in the learning college. Learning Abstracts: Published by the League for Innovation in the Community Colleges, volume 2 , number 3 .

Nussbaum, T.J. (1995). Evolving Community College Shared Governance to better serve the public interest. California Community Colleges. Sacramento, CA: California Community Colleges. (ERIC Document Reproduction Services No. Ed 397 922).

$$
\text { Nussbaum, T.J. \& Cabaldon, C.L. (1999, March). }
$$
Developing Contingent Funding Methods for the Partnership for Excellence: A Chancellor's Office Working Paper. California Community College Chancellor.

Office of Program Policy Analysis and Government Accountability (OPPAGA). (1997, April). Performance-Based Program Budgeting in context: History and comparison. Tallahassee, FL. OPPAGA Report Production. Report 86-77A. 
Patton, M. Q. (1990). Qualitative evaluation and research methods. $\left(2^{\text {nd }}\right.$ ed. $)$. Newbury, Ca.: Sage Publications.

Peters, T. (1988). Thriving on chaos: Handbook for a management revolution. New York: Alfred A. Knopf.

Public Agenda. (2000). Great expectations: A view from the states. [Announcement posted on the World Wide Web.] Retrieved September 2, 2000 from the World Wide Web: http://www. highereducation.org.

Rubin, H. J., \& Rubin, I. S. (1995). Qualitative interviewing: The art of hearing data. Thousand Oaks, Ca. Sage Publications.

Shadish, W.R., Cook, T.D., \& Leviton, L.C. (1991) Responsive Evaluation and Qualitative Methods, Robert E. Stake (p. 270-314). Newbury Park, CA: Sage Publications. Sims, R.A. (1998, March). Shared Governance-A Wasteful Exercise? Administrator, p.3.

Southern Association of Colleges and Schools Commission on Colleges (SACS) [Announcement posted on World Wide Web]. Retrieved November 8, 2000 from the World Wide Web: http://Www.sacscoc.org.

Spradley, J. P. (1979). The ethnographic interview. Orlando, Fl: Holt, Rienhart \& Winston, Inc. 
Statewide Academic Senate: News. (2002, February). Commission urged to reconsider: New Accreditation standards would impose corporate approach. Perspective. (p.3).

The Institute for Higher Education Policy. (1998, March). Reaping the Benefits: Defining the Public and Private Value of Going to College. The Millennium Project on Higher Education Costs, Pricing, and productivity. Sponsored by the Institute for Higher Education Policy, The Ford Foundation and the Education Resources Institute.

The New Millennium Project on Higher Education Costs, Pricing, and Productivity. (1998, March). Reaping the benefits: Defining the public and private value of going to college. Sponsored by The Institute for Higher Education Policy, The Ford Foundation and The Education Resources Institute.

Trombley, W. (1997, February). Community colleges shared governance: An elusive goal. A supplement to CrossTalk, v. 5, no.1, The California Higher Education Policy Center.

Vaughan, G. B. (2000). The Community College story. $\left(2^{\text {nd }}\right.$ ed. $)$. Washington, D.C.: American Association of Community colleges.

Wendell, P.J. (1981). Corporate Controller's Manual. Boston, MA: Warren, Gorman \& Lamont, Inc. 
Western Association of Schools and Colleges (WASC). [Announcement posted on World Wide Web]. Retrieved October 30, 2000 from the World Wide Web: http://www.wasc.org.

Wheatley, M. J. (1994). Leadership and the new science. (pp. 51-73). San Francisco, Ca.: Berrett-Koehler.

Williams, C. (2003). Management (2 ${ }^{\text {nd }}$ ed.). Mason, OH: South-Western.

Wirth, P. (1991). Shared governance: Promises and

perils. Yuba Community College District, Marysville, Ca. (ERIC Document Reproduction Services No. ED 331568. 


\section{Appendices}




\section{Appendix A}

Formal letter of introduction

XYZ Street

San Diego, Ca. 12345

January 8,2001

Chancellor Thomas J. Nussbaum.

California Community Colleges

1107 Ninth Street

Sacramento, Ca. 95814-3607

Dear Chancellor Nussbaum:

I am a doctoral student at the University of San Diego conducting a dissertation study entitled "The Relationship Between Governance and Accountability in Community Colleges: A Cross-Case Analysis." I have chosen this topic because educational accountability is one of the most widespread concerns facing community colleges today. However, I believe this issue must be addressed particularly in relationship to the type of governance model employed within the community college system/district. An abstract of the study is enclosed.

I am requesting an hour of your time to conduct an interview of your community college system/district at a time convenient to you. A prepared list of interview questions can be made available to you in advance should you agree to this process. The interview will be audio taped and all information will be held in the strictest confidence. Enclosed is a consent form that I will collect from you at the time of the interview should you agree to participate in this study.

This letter will be followed by a telephone call from me within a week's time to confirm your agreement to the interview and arrange an appointment convenient to your schedule. In the interim you may reach me at (123) 456-7890 or via e-mail at bdowd@palomar.edu if you have any questions related to this interview.

Thank you for considering participating in this study.

Sincerely,

Bonnie Ann Dowd,

Doctoral student 


\section{Appendix B \\ Consent Form \\ [State (System)]}

Bonnie Ann Dowd is conducting a case analysis of your state community college system in partial fulfillment for the degree of Doctor of Education, from the University of San Diego. The purpose of this case study is to gain further insight and understanding of the effect of a community college system's governance on its ability to create, implement and institutionalize a successful accountability program.

As a respondent in this study, I understand I will participate in one individual interview that should last no longer than 60 minutes in duration. There may be a follow-up inquiry that will take no more than 20 minutes. This follow-up may be handled through e-mail or telephone discussion. My participation in this study is entirely voluntary and I understand I may refuse to participate or withdraw at any time without penalty. There are no expenses that I must incur associated with this study.

I understand that these interviews will be audio taped and transcribed for analysis and that my identity will remain confidential. Participation in this study may involve a minimal risk of loss of confidentiality; however, the researcher will take all necessary precautions to eliminate or reduce this risk. The data for this study will be used in Ms. Dowd's dissertation, and may be used in subsequent articles and manuscripts.

I also understand that if I wish I might review the audiotape, the transcription and the final report.

There are no other agreements, written or verbal, related to this study beyond that expressed in this consent form. Bonnie Ann Dowd has explained the research project to me and answered my questions. I understand that if I have further questions I may contact Bonnie Ann Dowd at any time at (123) 456-7890 or by e-mail at bdowdepalomar.edu. I may also contact the dissertation committee chair, Dr. Paula A. Cordeiro at (619) 260-4282 or by e-mail at cordeirodacusd.edu.

I, the undersigned, understand the above explanations and on that basis, I give consent to my voluntary participation in this research.

Signature of Subject

Location

$\overline{\text { Signature of Principal Researcher }}$

Signature of Witness
Date

Date

Date 


\section{Appendix C \\ Consent Form \\ [Local (College)]}

Bonnie Ann Dowd is conducting a case analysis of your community college in partial fulfillment for the degree of Doctor of Education, from the University of San Diego. The purpose of this case study is to gain further insight and understanding of the effect of a community college district's governance on its ability to create, implement and institutionalize a successful accountability program.

As a respondent in this study, I understand I will participate in one individual interview that should last no longer than 60 minutes in duration. There may be a follow-up inquiry that will take no more than 20 minutes. This follow-up may be handled through e-mail or telephone discussion. My participation in this study is entirely voluntary and I understand I may refuse to participate or withdraw at any time without penalty. There are no expenses that I must incur associated with this study.

I understand that these interviews will be audio taped and transcribed for analysis and that my identity will remain confidential. Participation in this study may involve a minimal risk of loss of confidentiality; however, the researcher will take all necessary precautions to eliminate or reduce this risk. The data for this study will be used in Ms. Dowd's dissertation, and may be used in subsequent articles and manuscripts.

I also understand that if I wish I might review the audiotape, the transcription and the final report.

There are no other agreements, written or verbal, related to this study beyond that expressed in this consent form. Bonnie Ann Dowd has explained the research project to me and answered my questions. I understand that if I have further questions I may contact Bonnie Ann Dowd at any time at (123) 456-7890 or by e-mail at bdowdepalomar.edu. I may also contact the dissertation committee chair, Dr. Paula A. Cordeiro at (619) 260-4282 or by e-mail at cordeiro@acusd.edu.

I, the undersigned, understand the above explanations and on that basis, I give consent to my voluntary participation in this research.

Signature of Subject

Location

Signature of Principal Researcher

Signature of Witness $\overline{\text { Date }}$

\section{Date}

Date 


\section{Appendix D \\ Interview Question Guide \#1 \\ [State (System) Participants]}

1. Please describe the decision-making process used to govern your state's community college system? (RQ 1)

2. Please describe how your state system's decisionmaking process has affected any attempt at addressing educational accountability? Program-based funding? Student performance outcomes? (RQ 2)

3. To what extent, if at all, has the decision-making process used in governing community colleges in your state hindered or helped in the implementation of state initiatives associated with accountability regarding student performance outcomes? ( $R Q$ 2, 3)

4. Would you please share with me your understanding of the circumstances that lead to the development of PFE $\left(\mathrm{PB}^{2}\right)$ for your community college system? (RQ 4)

5. What role did your state's decision-making process play in impeding or advancing the formation and implementation of the performance-based funding program currently in existence in your state system ( $\mathrm{PFE}$ in California, $\mathrm{PB}^{2}$ in Florida)? (RQ 4)

6. Do you believe the $\mathrm{PFE}\left(\mathrm{PB}^{2}\right)$ program has been successful in addressing educational accountability? If yes, why? If not, why not? (RQ 4) 
7. If you could make changes to the $\mathrm{PEE}\left(\mathrm{PB}^{2}\right)$ initiatives used by your state/system, what changes would you make? (RQ 1, 2)

8. If you could change the type of decision-making process used in your state system, what changes would you make? (RQ 1)

9. What would you like for me to know about the California (Florida) community college system's decision-making process and/or efforts at educational accountability that I haven't inquired about? Why do you think it is important for me to know this fact/information? ( $R Q$ 1-4)

10. What other individuals do you think would serve as valuable interview resources for this study? (RQ 1-4) 


\section{Appendix E \\ Interview Question Guide \#2 \\ [Local (College) Participants]}

1. Please describe the decision-making process currently used to govern your college? (RQ1)

2. How do you think key stakeholders at the state system level (e.g., California's State Chancellor (Florida's State Executive Director), state Board of Governors and legislators perceive the decision-making process used in your state's community college system? (RQ 1)

3. Please describe to me how your state system's decision-making process has affected an attempt to address educational accountability? Program-based funding? Student performance outcomes? ( $R Q$ 2)

4. How has your college's governance model affected the allocation of resources? ( $R Q 2,3,4)$

5. To what extent, if at all, does local college governance ensure or detract from educational accountability? ( $R Q 2,3)$

6. To what extent, if at all, has the decision-making process used in governing community colleges in your state hindered or helped in the implementation of state programs associated with accountability regarding student performance outcomes? (RQ 2, 3) 
7. Would you please share with me your understanding of the circumstances that lead to the development of PFE $\left(\mathrm{PB}^{2}\right)$ for your community college system? (RQ 4)

8. What role do you perceive your state's decision-making process to have played in impeding or advancing the development and implementation of the performancebased funding program currently in existence in your state ( $\mathrm{PFE}$ in California, $\mathrm{PB}^{2}$ in Florida)? ( $\mathrm{RQ}$ 4)

9. How have individuals at the state/system level (e.g., State Chancellor (Executive Director), legislators, Board of Governors) impeded or helped your college/district's efforts with institutionalization of the $\mathrm{PFE}\left(\mathrm{PB}^{2}\right)$ initiative? (RQ 4)

10. Do you believe the PFE $\left(\mathrm{PB}^{2}\right)$ program has been successful in addressing educational accountability? If yes, why? If not, why not? (RQ 4)

11. If you could make changes to the $\mathrm{PFE}\left(\mathrm{PB}^{2}\right)$ initiatives used by your state's community college system, what changes would you make? (RQ 1,2$)$

12. If you could change the type of decision-making process used in your state system, what changes would you make? (RQ 1)

13. What would you like for me to know about the California (Florida) community college system's 
decision-making process and/or efforts at educational accountability that I haven't inquired about? Why do you think it is important for me to know this fact/information? (RQ 1-4)

14. What other individuals do you think would serve as valuable interview resources for this study? (RQ 1-4) 


\section{Appendix F \\ Document Review Analyzer}

The document review analysis process has been created to assist the researcher in the analysis of various documents to be reviewed during the course of this study. This process has been developed using the research questions as a guide. The analyzer's primary purpose is to assist in the collecting, sorting and coding of the data obtained in this portion of the study. Document analysis is subordinate to the actual data obtained through the interview process and will represent a small portion of the data to be analyzed. A case study is dependent upon the information-rich data that emerges from the process; therefore, the documents to be reviewed will merely provide a chronological and factual perspective to the study. Following is an initial list of the documents that the research anticipates reviewing; however, as with the entire study should the researcher become aware of other documents relevant to the issues, they will be included in this process.

- AB1725 (California's reform legislation which mandated "shared governance")

- PFE (California's Partnership for Excellence) 
- $\mathrm{PB}^{2}$ (Florida's Performance-Based Program Budgeting)

- California and Florida's state statues dealing with issues of governance, accountability and performance-based funding

- Florida's Amendment 8 of the state constitution which called for a new governance model

- $\mathrm{PB}^{2}$ Status reports (produced annually by OPPAGA)

- California State Chancellor's annual PEE reports

- Websites of both the California State Chancellor and Florida Executive Director regarding current issues

Each document was reviewed to determine the rationale for the legislation or program; events which lead to the legislation or program; how long it has been in existence; advantages and disadvantages; implications at both the state and local level; evidence of success or failure. An illustration of the analyzer and how it might be used to review a document is provided at Figure 1. 
Figure 1. Assembly Bill 125 (AB1725) Legislation

\begin{tabular}{|c|c|}
\hline \multicolumn{2}{|l|}{ Document Review Analyzer } \\
\hline \multicolumn{2}{|c|}{ 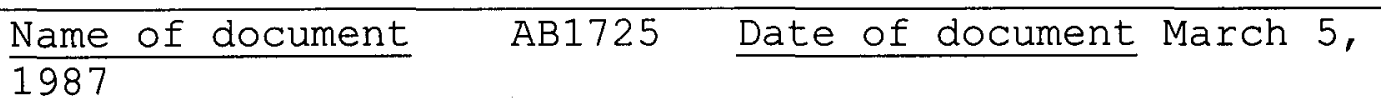 } \\
\hline $\begin{array}{l}\text { Type of document } \\
\text { Assembly bill legislation }\end{array}$ & $\begin{array}{l}\text { Governance (decision-making) } \\
\text { Yes - established shared } \\
\text { governance through the } \\
\text { Consultation Process }\end{array}$ \\
\hline $\begin{array}{l}\text { Accountability } \\
\text { Called for development of } \\
\text { an accountability model } \\
\text { for community college }\end{array}$ & $\begin{array}{l}\text { Performance-based funding } \\
\text { Implemented program-based } \\
\text { funding }\end{array}$ \\
\hline \multicolumn{2}{|c|}{$\begin{array}{l}\text { Summarized highlights of the document } \\
\text { Validated CCC making it a system and clarified CCC's } \\
\text { mission } \\
\text { Delineated state and local roles } \\
\text { Established system of shared governance through the } \\
\text { "consultation process" } \\
\text { Faculty roles strengthened }\end{array}$} \\
\hline $\begin{array}{l}\text { Implications at state } \\
\text { level } \\
\text { Clearly defined the role } \\
\text { of the State Chancellor } \\
\text { and the state Board of } \\
\text { Governors (BOG) } \\
\text { Established consultation } \\
\text { process in order for } \\
\text { input to be solicited } \\
\text { from all constituency } \\
\text { groups throughout the } \\
\text { state }\end{array}$ & $\begin{array}{l}\text { Implications at college } \\
\text { level } \\
\text { Shared governance defined at } \\
\text { state level through } \\
\text { consultation process but no } \\
\text { clear procedures for } \\
\text { implementation at the } \\
\text { college level } \\
\text { Limited the ability of local } \\
\text { trustees to raise funds for } \\
\text { the needs of district }\end{array}$ \\
\hline $\begin{array}{l}\text { Date (s) reviewed } \\
\text { November } 14,2000\end{array}$ & $\frac{\text { Coding Information }}{\text { Roles of constitue }}$ \\
\hline
\end{tabular}

